\title{
Kişi ve Eşya Ayrımı Bağlamında Hayvanların Hukuki Statüsü
}

\author{
Özgün Çelebi* $\odot$
}

öz

Hayvanları kullanma ve kontrol etme yönündeki ihtiyaçlarımız, onların öteden beri eşya olarak, başka bir deyişle hakların öznesi değil, konusu olarak sınıflandırılmalarına sebep olmuştur. Bununla beraber, hayvanların hissetme yetisine ilişkin bilimsel verilerin gelişmesi ile, hayvanlarla ilişkilerimiz onların da birer canlı varlık olmaları bilincine paralel olarak evrilmiş, hukuk kuralları da bu evrimi yansıtır hale gelmiştir. Hayvanları kendi menfaatleri için koruma amacını güden ve onları diğer eşyalardan farklı bir hukuki rejime tabi tutan normlar, hukuk sistemlerinde gittikçe daha fazla yaygınlık kazanmakta, hayvanlar, kendine özgü bir hukuki statüye doğru itelenmektedir. Gerek yapılmış olan düzenlemelerin hukuki etkisinin anlaşılması, gerekse hayvan hakları hukukunun ne yönde evrilmesi gerektiği sorusunun cevaplandırılması, hayvanların hukuki statüsünün, özel hukuk sistemimizin temel ayrımlarından biri olan kişi ve eşya ayrımı çerçevesinde yeniden değerlendirilmesini zorunlu kılmaktadır. Hayvanların statüsü açısından çağdaş sistemlerde oluşan hukuki tablonun ortaya konulması ve en yerinde olan çözümün arayışı, bizi, diğer canlı varlıklar, embriyo, kadavra, yapay zeka gibi sorunsallar açısından da önem taşıyan, hak öznesi ile hak nesnesi arasındaki geleneksel ilişkiyi de sorgulamaya götürecektir.

\author{
Anahtar Kelimeler \\ Hayvan hakları • Kişi ile eşya ayrımı • Mülkiyet hakkının sınırlandırılması • Hayvan onuru • Hayvan refahı
}

\section{Legal Status of Animals with Regards to the Distinction between Persons and Things}

\begin{abstract}
Our need for using and controlling animals has traditionally led to the classification of animals as things, namely as objects, and not subjects of rights. Nevertheless, consequently to the development of scientific data as to animal sentience, our relationship with animals has evolved in parallel to our awareness regarding their peculiarities as living beings, and legal norms have begun to reflect this evolution. Rules that target protection of animals for the sake of their own interests and expose them to a different regime than other things have gradually expanded and animals have been dragged to a sui generis legal status. Comprehension of the legal effect of such rules and determination of the direction in which the animal law should proceed requires re-evaluation of the legal status of animals with regards to the distinction between persons and things, one of the summa divisio of our private law system. Exposure of the legal landscape regarding animals in modern law systems and quest of the most appropriate solution will lead to the interrogation upon the traditional relationship between the concepts of subject and object of rights, which may have importance also with respect to other living beings, embryos, corpses or artificial intelligence.
\end{abstract}

\section{Keywords}

Animal rights $\bullet$ Distinction between person and thing $\bullet$ Limitation of property rights $\bullet$ Animal dignity $\bullet$ Animal welfare

\footnotetext{
* Sorumlu Yazar: Özgün Çelebi (Dr. Öğr. Üyesi), Koç Üniversitesi, Hukuk Fakültesi, Medeni Hukuk Anabilim Dalı, İstanbul, Türkiye. Eposta: ozgcelebi@ku.edu.tr

Atrf: Çelebi, Özgün, “Kişi ve Eşya Ayrımı Bağlamında Hayvanların Hukuki Statüsü”, i̇stanbul Hukuk Mecmuası, 76/2, 2018, 559-622. https:// doi.org/10.26650/mecmua.2018.76.2.0025
} 


\section{Extended Summary}

Our need for using and controlling animals has traditionally led to the classification of animals as things, namely as objects, and not subjects of rights. Nevertheless, consequently to the development of scientific data as to animal sentience and animal cognition, the anthropocentric approach that considers the human being as the center of the universe has begun to fade away. Our relationship with animals has evolved in parallel to our awareness of their quality of living beings, and law has begun to reflect this evolution through creation of rules, which designate animals as the aim of the legal protection, and not merely as instruments at the service of human beings. Comprehension of the legal effect of such rules and determination of the direction in which the animal law should proceed requires re-evaluation of the legal status of animals with regards to the distinction between persons and things, one of the summa divisio of our private law system

The concessions that human beings are willing to make for the benefit of animal welfare are determined differently depending on the needs and values of each society, leading to a high level of diversity in legal steps taken by different countries. Studying Swiss, German and French laws which share similar principles with our private law system and which have taken concrete steps for improvement of legal status of animals, one can observe that some of the rules relating to animal protection aim primarily to protect the animal owners' interests and as such, do not depart from the tradition which classify animals as objects of rights. Nevertheless, some other rules aim to protect animals for their own interests, and impose restrictions to human behavior exclusively to this effect. In this regard, besides detailed regulations issued under the form of animal protection laws, as is the case in our legal system, amendments of more fundamental nature in different areas of civil law are noteworthy. In particular, exclusion of animals from the category of things in civil codes and the development of "animal dignity" concept reflect a paradigm shift based on the prioritization of animals' inherent value. Norms aiming at their protection for their own interests and exposing them to a specific legal regime drive animals towards to a sui generis legal status. In some countries, the aim of protection of animals for their own sake has also become a constitutional principle and consequently, legislative, executive and judicial organs have been entrusted with the duty of ensuring the continuity of this evolution.

In the presence of such legal limits to human behavior for the protection of animals' interests, it seems difficult to continue to classify animals as mere things. Once this point accepted, one can observe three groups of propositions of solution. Some scholars defend the classical understanding of the distinction between persons and things and the classification of animals under the second category, but consider animals as a special category of things. Others who underline insufficiencies of the 
distinction between persons and things argue that animals are neither things nor persons, and thus constitute an intermediate category between persons and things. Finally, scholars who attach personhood to the fact of having legally protected interest argue that the conditions for animals to be accepted as persons or as quasi-persons are satisfied. Accordingly, animals must enjoy a "technical" legal personhood, adapted to their needs, and an efficient tutorship mechanism, enabling them to use the rights attached to such personhood.

It has been argued that it would be contradictory to accept animals as something other than things, as long as they remain objects of property right. However, pretending that beings protected by the legal system directly for their own interests do not enjoy any rights also leads to a contradiction. Accepting that a being has its own interest worthy of protection amounts to the recognition of this being as an objective in itself as long as such interests are at stake, rather than as a tool for satisfaction of others' interest, which is the fate of things. Legal repercussions of our relationship with animals lead to the recognition of animals partially as objects and partially as subjects of rights and demonstrate that the relationship between the categories of persons and things, accepted to be mutually exclusionary, has become questionable in face of some modern classification problems. Interrogations upon the intransigent character of such distinction and to what extent intermediary layers can be acceptable bear importance not only for the status of animals, but also for the proper legal integration of some other beings which have gained new meanings in modern societies, such as plants, other components of environment, human corpse or artificial intelligence. 


\section{Giriş ${ }^{1 *}$}

İnsanların genel olarak çevre ile ve özel olarak hayvanlarla olan ilişkilerini insan merkezli yaklaşımdan uzaklaştırma ve yeniden yapılandırma ihtiyacı her geçen gün daha çok dile getirilmektedir². Hayvanları doğanın ürettiği birer makine olarak sınıflandıran kartezyen düşüncede kristalleşen ${ }^{3}$, bu varlıkları münhasıran insanların hizmetindeki araçlar olarak gören geleneksel kabul artık çağdaş toplumların anlayışını yansıtmaktan uzaktır. Hayvanların araç olmaktan çıkmaları ve insanlara karşı korunmaları amacı çerçevesinde gelişmekte olan düşünceler hukuki planda da etki kazanmaktadir ${ }^{4}$.

Ancak bu korumanın ne şekilde gerçekleşebileceği sorusuna geldiğimizde bu amaca ulaşmanın hiç de kolay olmadığını görmekteyiz. En hayvansever olanlarımızın dahi bu varlıklarla olan ilişkisi büyük çelişkiler barındırmakta, gerek doğaya olan bakışımızın antroposantrik niteliği, gerekse hayvanlara olan ekonomik bağımlılı̆ımız onları ihlal edilemez haklara sahip canlılar olarak görmemize engel olmaktadır. Bir yandan evlerimizde çeşitli hayvanlar beslemekte, bazı hayvanları can yoldaşı olarak görmekte, sokaktaki kimsesiz hayvanlara kötü muamele yapılmasından rahatsızlık duymaktayız. Öte yandan hayvanların eziyetli şartlar altında çalıştırılmakta, sergilenmekte, deneylerde ve salt eğlence amaçlı aktivitelerde kullanılmakta olduğunu bilmekte ${ }^{5}$, ancak kendi çıkarlarımız adına bu halleri mazur görmekteyiz. Ne şekilde tutulduğunu, bakıldığını ve kesildiğini bilmediğimiz hayvanları gıda olarak tüketmekte, zararlı ve hatta sadece sevimsiz bulduğumuz hayvanları öldürmekteyiz. Hayvanların insanların hizmetinde birer eşya olarak görüldüğü, insan merkezli yaklaşımımız ile hayvanların insanlarla olan benzerliklerine, özellikle acı çekme yetilerine vurgu yapan bilimsel verilere paralel

"Bu çalışmada kullanılan Fransız temyiz mahkemesi kararlarına https://www.legifrance.gouv.fr adresinden, İsviçre Federal Mahkemesi kararlarına https://www.bger.ch adresinden erişim sağlanmıştır (Son E.T. 21.11.2018).

2 Doğadaki varlıklara haklar tanınması gereğine ilişkin olarak, bkz. Christopher D. Stone, "Should Trees Have Standing? Toward Legal Rights for Natural Objects”, Southern California Law Review, C. 45, 1972, s. 450 vd.

3 Descartes'a atfedilen “hayvan-makine” görüşü üzerine bir inceleme için, bkz. Emre Arda Erdenk, “Descartes' Account of Feeling of Pain in Animals", Felsefe ve Sosyal Bilimler Dergisi, S. 15, Bahar 2013, s. 202 vd.

4 Batı kültüründe hayvanları koruyan hukuk kurallarının tarihi gelişimi için, bkz. Thomas Kelch, "A Short History of (Mostly) Western Animal Law, Part I", Animal Law Review, C. 19, 2012, s. 23-62 ; Thomas Kelch, "A Short History of (Mostly) Western Animal Law, Part II", Animal Law Review, C. 19, 2013, s. 347-390. Yazara göre hayvanların korunmasına ilişkin normlar dini amaçlar (kutsal değer taşıyan hayvanların korunması), ekonomik amaçlar (hayvanların mülkiyet hakkı konusu olarak değerlerinin korunması), sosyal mühendislik amacı (hayvanlara yapılan kötü muamelenin, insanın içindeki kötülüğün uyanmasını önlemek ve insanlar arasındaki ilişkileri iyileştirmek için engellenmesi), hayvanların kendileri için korunmaları amacı ve bilimsel hayvan refahını sağlama amacı (koruma standartlarının hayvanlar hakkındaki bilimsel verilere göre șekillenmesi) olarak sınıflandırılabilecek aşamalardan geçmiștir. Yazar, șu anda içinde olduğumuzu belirttiği bilimsel hayvan refahı dönemine örnek olarak Avrupa Birliği mevzuatını göstermektedir (Kelch, Part II, s. 370 vd). Hayvanların yakın doğu ve batı kültürlerinde eşya olarak kabulü üzerine bir inceleme için, bkz. Steven M. Wise, "The Legal Thinghood of Nonhuman Animals", Boston College Environmental Affairs Law Review, C. 23, 1996, s. 471 vd. Yazar, geçmişte hayvanların eşya olarak sınıflandırılmalarına sebep olan, insanın hiyerarşik üstünlügüne dayalı evren anlayışının bugün geçerliliğinin kalmadığını ve bu eskimiş anlayışın günümüz hukukunu yanlış önermelere dayalı olarak şekillendirmeye devam ettiğini belirtmektedir (s. 546). Hayvanları korumaya ilişkin ilk hukuki düzenlemelere bazı örnekler için, ayrıca bkz. Alper Uyumaz, "Bir Hukuk Sorunsalı Olarak Güncel Gelişmeler Iş̧ı̆ında Türkiye’de Hayvan Hakları", Gazi Üniversitesi Hukuk Fakültesi Dergisi, C. 20, S. 3, 2016, s. 159.

Çeşitli kültürlerde insanların hayvanlar üzerinde gerçekleştirdiği bazı acı verici uygulamalara örnekler için, bkz. Uyumaz, s. 135-137. 
olarak geliştirdiğimiz empati, çoğumuzun vicdanında sürekli savaş halindedir. $\mathrm{Bu}$ çelişkili ilişkiler yumağı, kendisini yasal düzlemde de göstermektedir. Bir yandan hayvanların daha iyi şartlara kavuşturulması için düzenlemeler yapılmakta, öte yandan, adeta bir "ahlaki şizofreni" içinde, hayvanların birer canlı varlık olarak en temel menfaatleri, insanoğlunun bazıları sadece keyfi nitelikte görülebilecek menfaatleri karşısında dahi kolaylıkla feda edilmektedir.

Hayvanları kullanma ve kontrol etme yönündeki ihtiyaçlarımız, onların öteden beri eşya olarak, yani hakların öznesi değil, konusu olarak sınıflandırılmalarına sebep olmuştur. İşte hayvan haklarına ilişkin gelişim kendini belki de en çarpıcı biçimde tam da bu alanda göstermektedir: Hayvanlar için diğer eşyalardan farklı bir hukuki rejim öngören normlar batılı hukuk sistemlerinde gittikçe daha fazla yaygınlık kazanmakta, hayvanlar, eşya ile kişi arası, kendine özgü bir hukuki statüye doğru itelenmektedir ${ }^{7}$. Bu gelişim bazen özel hukuk ilişkilerini düzenleyen genel kurallarda hayvanlara ilişkin farklılıkların yaratılması ${ }^{8}$, bazen de hayvanları koruma amaçlı olarak özel olarak ihdas edilen kanunların yeni davranış kodları belirlemesi ${ }^{9}$ biçiminde karşımıza çıkmaktadır. Bu çalışmanın amacı da, bu hukuki gelişmenin yarattığı tablonun ortaya konulması ve hayvanların hukuki konumunun, özel hukuk sistemimizin temel ayrımlarından biri olan kişi ve eşya ayrımı çerçevesinde

\footnotetext{
Saskia Stucki, "Rechtstheoretische Reflexionen zur Begründung eines tierlichen Rechtssubjekts”, in: Animal Law-Tier und Recht, Developments and Perspectives in the 21st Century, ed. Michel Margot/Kühne Daniela/ Hänni Julia, Zürih/St. Gallen 2012, s. 147-148.

Bazı ülkelerde bu konuda esaslı adımlar atılmamış olması, bazı ülkelerde ise atılan adımların değişik konulara ilişkin olması sistematik bir karşılaştırmalı hukuk incelemesi yapılmasına engel olmaktadır. Bu çeşitlilik karşısında bu çalışma kapsamında karşılaştırmalı hukuk incelemesinde temel olarak hayvanların statüsünü iyileştirme yönünde somut adımlar atmış olan İsviçre, Alman ve Fransız hukukları incelenmiştir.

8 Bazı ülkelerde bu konuda toplu biçimde norm değişikliğine gidilmiştir. Almanya'da 20 Ağustos 1990 tarihli Özel Hukukta Hayvanların Hukuki Durumunun İyileştirilmesine Yönelik Kanun (Gesetz zur Verbesserung der Rechtsstellung des Tieres im bürgerlichen Recht) ile Alman Medeni Kanunu'nda (BGB) ve Alman Medeni Usul Kanunu'nda (ZPO) değişiklikler yapılmıştır. İsviçre'de benzer bir girişim 4 Ekim 2002 tarihli kanun ile gerçekleştirilmiş ve hayvanların hukuki statüsünü iyileştirmek amacıyla İsviçre Borçlar Kanunu (IBK), İsviçre Medeni Kanunu (IMMK), İsviçre Ceza Kanunu ve İsviçre İcra ve İflas Kanunu'nda (İïKK), hayvanları diğer eşyalardan farklı kurallara tabi tutan düzenlemeler yapılmıştır. Kanun gerekçesinde yapılan değişikliklerin amacı, toplumun hayvanlara karşı olan yeni hassasiyetini dikkate almak ve hayvanların hukuki statüsünü iyileștirmek olarak açıklanmıştır. Gerekçede, toplumun büyük bir kesiminin Roma hukukundan gelen hayvan-eşya anlayışını artık benimsemediği, bunun da örneklerinden birinin bir hayvanın yaralanmasını bir eşyanın hasar görmesi ile bir tutan yürürlükteki hukuk kurallarının gittikçe artan bir şekilde anlaşılmaz bulunması olduğu da belirtilmiştir (Komisyon Raporu, s. 3887, https://www.admin.ch/opc/fr/federal-gazette/2002/3885.pdf, E.T. 21.11.2018).

9 İsviçre'de hayvanların korunması amacıyla 9 Mart 1978'te çıkarılan kanun 1 Temmuz 1981'de yürürlüğe girmiş ve 2008'e kadar yürürlükte kalmıştır. Bugün yürürlükte olan 16 Aralık 2005 tarihli Hayvanları Koruma Kanunu (Loi fédérale sur la protection des animaux) ve buna dayalı olarak çıkarılan 23 Nisan 2008 tarihli yönetmelik ise 1 Eylül 2008'de yürürlüğe girmişlerdir. (Kanun metni için bkz. https://www.admin.ch/opc/fr/classified-compilation/20022103/201705010000/455. pdf, E.T. 21.11.2018). Alman Hayvanları Koruma Kanunu (Tierschutzgesetz) 24 Temmuz 1972 tarihlidir ve zaman içinde Avrupa Birliği müktesebatı ile de uyumun sağlanması amacıyla çeşitli değişikliklere uğramışıtır (Kanun metni için bkz. https://www.gesetze-im-internet.de/tierschg/BJNR012770972.html, E.T. 21.11.2018). Avusturya'da Hayvanları Koruma Kanunu (Tierschutzgesetz) 1 Ocak 2005'te yürürlüğe girmiştir. Fransız hukukunda hayvanları koruyucu hükümler daha dağınık bir görünüme sahiptir; ancak İsviçre ve Alman hayvanları koruma kanunlarına en yakın düzenlemeler Köy ve Deniz Balıç̧ılığı Kanunu'nun (Code rural et de la pêche maritime) ikinci kitabının birinci kısmının dördüncü bölümünde "Hayvanların Korunması" başlığı ile yer almaktadır (Kanun metni için bkz. https://www.legifrance.gouv.fr, E.T. 21.11.2018). Kıta Avrupası hukuk sistemi dışında kalan ülkelerde de bu konuda benimsenmesi istenen davranış kuralları benzer kanunlar ile kodifiye edilmiştir; örnek olarak Birleşik Krallık’ta yürürlükte olan 8 Kasım 2006 tarihli Hayvan Refahı Kanunu (Animal Welfare Act) gösterilebilir (https://www.legislation.gov.uk/ukpga/2006/45/contents, E.T. 21.11.2018). Hukukumuzda da 24 Haziran 2004 tarihinde kabul edilmiş olan 5199 sayılı Hayvanları Koruma Kanunu 1 Temmuz 2004'te Resmi Gazete'de yayımlanarak yürürlüğe girmiş̦tir.
} 
değerlendirilmesidir. $\mathrm{Bu}$ amaçla, öncelikle hayvan hakları hukukunun güncel eğilimlerinin bazıları hatırlatılacak (II), ardından hayvanları münhasıran hakların konusu olarak nitelendiren geleneksel hukuki anlayışın günümüzde ne kadar geçerli olduğu incelenecektir (III).

\section{Hayvan Hakları Hukukunun Güncel Eğilimleri}

Hayvan hakları hukukunun gelişimine sekte vuran temel etken, insanoğlunun hangi hayvanlar için ne tür ödevler yüklenmeye, kendi menfaatlerinden ne tür tavizlerde bulunmaya hazır olduğu konusunda genel bir davranış etiğine ulaşamamış olmasıdır. Hayvanlarla olan ilişkilerimizi düzenlemekte dayanabileceğimiz değişik bakış açıları, Avrupa ve Anglo-Saxon öğretilerinde farklı isimlerle adlandırılmış ve hukuki planda da etki gösteren kamplaşmalara yol açmıştır.

Avrupa öğretisinde, bu alandaki yaklaşım farklılıkları antroposantrik yaklaşım ile etik yaklaşım üst başlıkları altında toplanmaktadır. "Antroposantrik” yaklaşım, insanı evrenin merkezine koymakta ve hayvanların korunmasını insanoğlunun da bunda çıkarının bulunması ölçüsünde kabul etmektedir. "Etik" yaklaşım ise hayvanların da canlı varlıklar olarak korunmaya değer menfaatlere sahip olduğunu ve hayvanların insanlar için değil, kendilerine ait menfaatleri için korunmaları gerektiğini savunur ${ }^{10}$. Hayvanları araç değil, amaç olarak gören bu modern yaklaşım da iki farklı çizgi çerçevesinde gelişmiştir. "Patosantrik" anlayış, hayvanların başlıbaşına korunmaya değer olan menfaatlerini, hayvanların acı çekme, hissetme kabiliyetine göre değerlendirir. "Biyolojik" anlayış ise, hukuken korunmaya mazhar menfaatlere sahip olmayı canlı varlık olma niteliğine ve canlı varlığın içsel değerine bağlamaktadır ${ }^{11}$.

Anglo-Sakson öğretide ise hayvan haklarının gelişiminde benimsenebilecek yaklaşımlar refah teorisi ve hak teorisi olarak bilinmektedir. Refah teorisi, hayvanları mülkiyet hakkının konusu olarak görmekle beraber hayvanların yaşam şartlarını iyileştirmeyi ve gereksiz olarak acı çekmelerini engelleyici yasalara ulaşılmasını hedeflemektedirr' ${ }^{12}$ Bu yaklaşım, hayvanların menfaatlerinin "gerekli” görülen insan

10 Ayrım için bkz. Stucki, Rechtstheoretische Reflexionen, s.146; Gieri Bolliger, "Legal Protection of Animal Dignity in Switzerland: Status Quo and Future Perspectives", Animal Law Review, C. 22, 2016, s. 354; Saskia Stucki, "Die «tierliche Person» als Tertium datur -Eine Extrapolation aus aktuellen tierschutzrechtlichen Subjektivierungsansätzen und kritische Reflexion aus feministischer Perspektive", in: Würde der Kreatur- ethische und rechtliche Beiträge zu einem umstrittenen Konzept, ed. Ammann Christoph/ Christensen Birgit/ Engi Lorenz/ Michel Margot, Schulthess 2015, s. 294; Margot Michel, "Tierschutzgesetzgebung im Rechtsvergleich: Konzepte und Entwicklungstendenzen", in: Animal Law-Tier und Recht, Developments and Perspectives in the 21st Century, ed. Michel Margot/Kühne Daniela/ Hänni Julia, Zürih/St. Gallen, 2012, s. 599.

11 Bolliger, Legal Protection, s. 355; Michel, s. 599.

12 Karen Bradshaw, “Animal Property Rights”, University of Colorado Law Review, C. 89, 2018, s. 811; Gary L. Francione, "Animal Rights and Animal Welfare", Rutgers University Law Review, C. 48, 1996, s. 397. "Gereksiz acı çekme" kavramı, hayvanların acı çekmesinin engellenmesinin, ancak insan menfaatleri önemli ölçüde zarar görmediği ölçüde bir amaç olarak benimsenmiş olduğunu düşündürmektedir (Glenn Wright, "Animal Law and Earth Jurisprudence: A Comparative Analysis of the Status of Animals in Two Emerging Discourses", Australian Animal Protection Law Journal, C. 9, 2013, s. 7). Bununla beraber, hayvan refahı kavramının, hayvanların korunması kavramından daha ileri bir seviyeyi ifade ettiği, nitekim her hayvan türünün kendi biyolojik gereklerine uygun yaşam şartlarına kavuşturulmasını da gerektirdiği görüşü de savunulmuştur (Suzanne Antoine, Rapport sur le regime juridique de l'animal, ed. Fransa Adalet 
menfaatleri karşısında feda edilebileceği yönünde bir ahlaki anlayışa dayanmaktadır. Bu nedenle hukuk kurallarının da ancak hayvanların acı çekmelerinin "gerekli” olarak görüldüğü alanların daralması ile gelişmesini sağlamaktadır ${ }^{13}$. Hayvanların yaşam şartlarını iyileştirmeyi hedeflemekle birlikte insan menfaatini kural olarak hayvan menfaatinden üstün tutan bu yaklaşıma getirilen eleştiriler 1970'lerden itibaren yaygınlaşmaya başlamıştır ${ }^{14}$. Hayvanların, ahlaki olarak insanlarla eşit muamele görmeyi hak ettikleri, bu nedenle hayvanların korunmalarının, insan menfaatleri ile bağdaştığı ölçüde değil, bu menfaatlerle çatışmasına rağmen ulaşılması gereken bir amaç olduğu ortak paydasında birleşen düşünürlerin ileri sürdüğü farklı görüşler, hayvan hakları teorisi (rights theory/abolitionism) üst çatısı altında ifade edilmektedir ${ }^{15}$. Hayvan hakları teorisi altında hayvanların en azından temel hakların öznesi haline getirilmesini ve bazı açılardan mutlak biçimde korunmasını savunan

Bakanlığı (Ministère de la justice), Mayıs 2005, s. 27-28, https://www.ladocumentationfrancaise.fr/var/storage/rapportspublics/054000297.pdf, E.T. 21.11.2018).

13 Örneğin, bazı zamanlarda ve toplumlarda hayvanların eğlence amaçlı kullanılmaları ve bu uğurda acıya maruz bırakılmaları insanların bu yöndeki menfaati karşısında "gerekli" görülebilirken, başka zamanlarda ve toplumlarda bu yöndeki insan menfaati üstün nitelikte görülmeyerek bu uğurda hayvanlara çektirilen acılar "gereksiz" olarak nitelendirilebilir. Eski toplumlarda olağan bir eğlence biçimi olan hayvan dövüşlerinin bugün pek çok ülkede mutlak biçimde yasaklanmış olması bu konuda yaşanan gelişime örnektir.

14 Francione, Animal Rights, s. 397.

15 Hayvan refahı teorisi ve hayvan hakları teorisi ayrımı ve karşılaştırmalı incelemesi için, bkz. Bradshaw, s. 819; Luis E. Chiesa, "Animal Rights Unraveled: Why Abolitionism Collapses into Welfarism and What It Means for Animal Ethics", Georgetown Environmental Law Review, C. 28, 2016, s. 559 vd.; Wright, s. 8 vd.; Gary L. Francione / Robert Garner, The Animal Rights Debate- Abolition or Regulation?, Columbia University Press, 2010, s. 1 vd.; Francione, Animal Rights s. 400 vd.; hayvan hakları teorisinin eleştirisi için, bkz. Chiesa, s. 568 vd. Hayvanlarla olan ilişkilerimizde acı çekmenin engellenmesinin ötesinde ahlaki ödevlerimiz bulunduğunu savunan, bu nedenle hak teorisi içinde sınıflandırılan düşünürlerin kendi aralarında da önemli fikirsel ayrılıklar bulunmaktadır. Hak merkezli yaklaşımın gelişiminde tetikleyici unsurlardan birinin Avusturalyalı felsefeci Peter Singer'in 1975 tarihli "Animal Liberation" isimli eseri olduğu kabul edilmektedir. Faydacı filozof, insan davranışlarının sonuçları ve toplam fayda unsuru değerlendirilirken, bu davranıştan etkilenen herkesin, bu arada hayvanların da menfaatlerinin hesaba katılması gerektiğini ileri sürmüștür. Singer'a göre hayvanların menfaatlerinin bu hesabın dışında tutulması "türcü" (speciest) bir yaklaşıma dayanmaktadır ve hayvanları insanlardan salt hayvan olmaları nedeniyle ayrı tutmayı öngören türcü yaklaşım, ahlaki olarak ırkçılıktan ve cinsiyetçilikten daha savunabilir değildir (aktaran, Francione, Animal Rights, s. 411). Bununla beraber Singer, faydacı felsefesi çeç̧evesinde hayvanlar ile insanların acı çekmeme yönünde eşit menfaate sahip olduklarını savumakta ve bazı hallerde hayvanların, bazı hallerde insanların bu menfaatlerinin feda edilebileceğini savunmaktadır. Singer'ın geliştirdiği bu felsefe, hayvanların korunması açısından mutlak bir çerçeve çizmemekte, ve bu nedenle düşünür bazı yazarlarca refah yaklaşımı içerisinde kabul edilmektedir (Chiesa, s. 563-564). Singer'ın menfaatlerin eşit önemsenmesi ilkesine dayalı, faydacı teorisi üzerine daha fazla bilgi için, bkz. Engin Arıkan, Hayvan Hakları İnsan Hukuku, Ekin Basım Yayın Dağıtım, Bursa, 2016 s. 15-58. Singer'1, faydacı yaklaşımı reddeden Amerikalı felsefeci Tom Regan takip etmiştir. Regan'a göre bireylerin içsel bir değerinin olması için yaşamı bilinçli olarak deneyimleyen varlıklar (experiencing subject of a life) olmaları yeterlidir; içsel değer sahibi olmak ise bu niteliğe saygı gösterilmesini ve bu varlıkların hiçbir koşulda araç olarak kullanılmamasını gerektirir (Aktaran Francione, Animal Rights s. 415 vd., ayrıca bkz. Arıkan, s. 60 vd.). Amerikalı hukukçular Steven Wise ile Gary Francione, hak teorisi akımının hukuk çalışmaları alanında en tanınan temsilcilerindendir. Bu yazarlar, refah yaklaşımının yetersizliği ve türcü niteliği üzerinde hemfikir olmakla beraber, hayvanların ne ölçüde insanların kullanımına tabi tutulabileceğine ilişkin farklı görüşler ileri sürmektedir; karşılaştırma için bkz. Francione, Animal Rights s. 410 vd.; Wise'ın teorisinin kısa açıklaması için bkz. Steven M. Wise, "Nonhuman Rights to Personhood", Pace Environmental Law Review, C. 30, 2013, s. 1278-1290; bu iki yazarın görüşleri için ayrıca bkz. aş. III-B-1. Steven Wise, kurucusu olduğu "Nonhuman Rights Project" (İnsan olmayanların hakları projesi) vasıtasıyla, özellikle tutsaklık altındaki hayvanların özgür bırakılmasına ilişkin davaların yürütülmesini sağlamaktadır. Bu hukuk mücadelesinin tanıtımı için bkz. Steven M. Wise, "Introduction to Animal Law Book", Syracuse Law Review, C. 67, 2017, s. 7 vd. Bu iki hukukçunun görüşleri için, ayrıca bkz. aş. III-B-1. Hayvanların korunması ekseninden çıkarak daha geniş bir perspektifte, insan varlığını doğanın bir parçası olarak gören ve hukuk kurallarının da ekolojik ilkeler ve doğanın koyduğu kurallar çerçevesinde şekillenmesini öngören "earth jurisprudence" teorisi için, bkz. Wright, s. 12 vd.; Judith E. Koons, "Earth Jurisprudence: The Moral Value of Nature", Pace Environmental Law Review, C. 25, 2008, s. 263 vd. Bu akım ise, üzerinde yaşadığımız dünyayı merkeze alarak, doğanın tüm unsurlarına aynı temel hakları tanımakta ve hayvanlara diğer varlıklardan farklı haklar tanımamaktadır. Dolayısıyla bu görüş çerçevesinde ekolojik sistemin sürdürülebilirliği açısından sorun yaratmadığı sürece hayvanların insanlar tarafından kullanılması ve tüketilmesi mümkün olabilir. 
yazarlardan bazıları, bu eşit muamele gereğini hayvanların acı çekme kabiliyetine, bazıları ise bilinç düzeyindeki gelişmişliğe bağlamakta ve bu tutamak noktaları yoluyla hayvanların, kişi/hak öznesi olarak kabul edilebilmeleri için yeterli derecede insan ile benzerlik gösterdiğini savunmaktadır ${ }^{16}$. Hak teorisi, hayvanların korunması sorununun temeline hayvanların insanlarca kullanılmakta olmasını oturturken, refah teorisi bu kullanımı ilke olarak sorgulamamakta, hayvanlara nasıl daha iyi davranabileceğimizle ilgilenmektedir ${ }^{17}$. Hak teorisi savunucularından olan Tom Regan iki görüşün arasındaki farkı, kafeslerin ortadan kaldırılması isteği (hak teorisi) ile daha büyük kafesler yapılması isteği (refah teorisi) arasındaki farka benzetmiştir ${ }^{18}$.

$\mathrm{Bu}$ anlayışlar, insanoğlunun hayvanlar lehine ne kadar fedakarlık yapmaya istekli olabileceğine ilişkin dereceleri yansıtmaktadır. Hukuk normunun bunlardan hangisine dayandığ 1 , etkisini hem korunacak hayvanların tanımlanması, hem de korumanın kapsamının belirlenmesi aşamasında göstermektedir. Günümüzdeki hukuki gelişim, hayvanlar için sağlanan korumanın, Avrupa öğretisi terminolojisiyle ifade edilirse, antroposantrik yaklaşımdan patosentrik yaklaşıma doğru ilerlemekte olduğunu göstermektedir. Başka bir deyişle hayvanları koruyucu normların önemli bir kısmı, hayvanları kendi menfaatleri için korumakta, ancak canlı varlık olma niteliklerinden çok, acı çekme yetilerine dayalı bir korumayı hedeflemektedir. Ayrıca bu korumanın kapsamı da ilgili hayvanı ne şekilde kullandığımız, ona ne kadar ihtiyacımız olduğuna göre esaslı biçimde değişmektedir. Böylece karşımıza biyolojik ve işlevsel sınıflandırmalara dayalı hukuki hayvan kategorileri çıkmaktadır.

Kategorileştirme eğiliminin ilk ayağı, biyolojik verilere dayalı bir sınıflandırmaya dayanmaktadır. Bu noktada hayvan hakları hukuku açısından kilit kavramlar olan ve bu alandaki farklı yaklaşımları şekillendiren "sentience" ve "cognition" kavramları üzerinde kısaca durmak gerekir. Latince hissetmek anlamına gelen "sentire" filinden türemiş olan "sentience" kavramı, hayvan araştırmaları alanında bir hayvanın duygulara sahip olmasını, zevk alma ve acı çekme gibi bir dizi durum ve duyuların farkında bulunmasını ifade etmektedir"19. Bu yetinin dilimizde "hissetme yetisi", bu yetiye sahip olan hayvanların ise "duyarlı hayvanlar" olarak ifade edilmesi mümkündür. Hissetme yetisine dayalı koruma anlayışı, hayvanları bu özelliklerine

16 Bu görüşler için, bkz. Bradshaw, s. 820. Yazar, bu görüşlerin, her durumda bazı hayvanları kapsam dışında bırakmaları ve hayvanlar arasında insana benzerlikleri ölçüsünde bir hiyerarşi oluşturdukları gerekçesiyle yine tam bir başarı sağlamadığını savunmaktadır (s. 820-821); aynı fikirde, bkz. Richard A. Epstein, “Animals as Objects, or Subjects, of Rights”, University of Chicago Law School, John M. Olin Program in Law and Economics Working Paper No. 171 , 2002, s. 21 vd., https:// chicagounbound.uchicago.edu/cgi/viewcontent.cgi?article=1052\&context=law_and_economics, E.T. 21.11.2018. Baz1 yazarlar ise bilinç veya acı çekme kabiliyeti gibi türlere has bazı niteliklerin, hangi hayvanın ne tür haklardan yararlanması gerektiği noktasında önem taşıyabileceğini, ancak bu yetilerin tüm hayvanları canlı varlık olarak içeren yeni bir hukuki kategorinin tanımlanması üzerinde etkisinin olmaması gerektiğini savunmaktadır; bkz. David Favre, "Living Property: A New Status for Animals Within the Legal System”, Marquette Law Review, C. 93, 2010, s. 1043.

17 Miah Gibson, "The Universal Declaration of Animal Welfare”, Deakin Law Review, C. 16, I. 2, 2011, s. 544.

18 Aktaran, Gibson, s. 544-545.

19 Helen Proctor, “Animal Sentience: Where Are We and Where Are We Heading?”, Animals, C. 2(4), 2012, s. 631; hayvan duyarlılığı kavramı için ayrıca bkz. Valery Giroux, "Des droits legaux fondamentaux pour tous les etres sensibles", Klesis - Revue philosophie, C. 16, 2010 - Humanité et animalité, s. 134-138. 
göre sınıflandırarak koruma sağlamaktadır. "Cognition" kavramı ise hayvanların bilgiyi algılamaları, işlemeleri ve depo etmelerini sağlayan zihinsel sürece işaret etmekte olup ${ }^{20}$, dilimize "idrak yetisi" olarak çevrilebilir.

$\mathrm{Bu}$ ayrımların pozitif hukuka nasıl yansıdığına baktığımızda, temel tutamak noktasının hayvanın hissetme yetisi olduğunu görmekteyiz. Bir merkezi sinir sistemine sahip olmaları itibariyle omurgalı hayvanların duyarlı hayvan oldukları kabul edilmekte, omurgasız hayvanların ise, haklarında toplanabilen bilimsel verilerin yetersizliğine rağmen hissetme yetisine sahip olmadıkları kanısı yaygınlık taşımaktadır ${ }^{21}$. Bununla beraber, bugün bilimsel olarak ulaş1lan noktada, hissetme yetisinin tüm hayvanlar için, veya aynı tür içindeki farklı bireylerin karakteristiklerine göre belirlenebildiğinin söylenmesi de mümkün görünmemektedir ${ }^{22}$. Bu nedenle hayvanların korunması konusundaki çağdaş düzenlemeler, bir yandan omurgalı hayvanları korumanın merkezine almakta, öte yandan diğer hayvanlara da bu korumanın teşmil edilebilmesi ihtimalini de öngörmektedirler. İsviçre'de yürürlükte olan Hayvanları Koruma Kanunu'nun 2. maddesi, kanunun omurgal1 hayvanlara uygulanacağını, ancak -federasyonun yönetim organlarından olanFederal Konsey'in kanunun hangi omurgasız hayvanlara ne ölçüde uygulanacağını belirlemeye yetkili olduğunu ve bu yetkiyi kullanırken hayvanların hissetme yetileri üzerinde gerçekleştirilen bilimsel araştırmaların sonuçlarına dayanacağını öngörmüştür ${ }^{23}$. Birleşik Krallık'ta yürürlükte olan Hayvan Refahı Kanunu birinci maddesinde, kanunun uygulanacağı hayvan kavramını, insan dışındaki omurgalı canlılar olarak tanımlamış, ancak yetkili yerel otoritenin, belirli bir hayvan türünün acı çekme yetisine sahip olduğu yönündeki bilimsel kanıtları yeterli görmesi şartıyla, kanundaki hayvan tanımının kapsamını omurgasızları da içerecek şekilde genişletmeye yetkili olduğunu hükme bağlamıştır. Alman Hayvanları Koruma Kanunu ise, kural olarak tüm hayvanları kapsamı içine almış, ancak acı çekme yetisini de dikkate alarak farklı türler için dereceli bir koruma sistemi öngörmüştür ${ }^{24}$. Bu düzenlemeler, hayvan korumasının temelini acı çekme yetisine oturtmaları itibariyle Avrupa öğretisinde patosantrik anlayış olarak bilinen anlayış1 yansıtmaktadırlar. Avusturya'da yürürlükte olan Hayvanları Koruma Kanunu ise üçüncü paragrafında kanunun bütün hayvanlara uygulanabilir olduğunu açıkça hükme bağlamış ve böylece hayvanı canlı varlık olma niteliği nedeniyle korumayı hedefleyen biyosantrik anlayışa yaklaşmıştır. İleride değineceğimiz, hayvan onurunu ve hayvan yaşamını korumayı amaçlayan hukuki düzenlemeler de, hayvanları

\footnotetext{
Proctor, s. 631; hayvanlarda bilinç bulunup bulunmadığına ilişkin bazı bilimsel veriler için, bkz. Koons, s. 296 vd. Proctor, s. 632-634.

22 Muriel Falaise, "Pour une approche juridique de la protection animale", Communication au Colloque National de la Recherche dans les IUT, Université de Lyon I, 2008, s. 7, https://projet.liris.cnrs.fr/cnriut08/actes/articles/205.pdf, E.T. 21.11.2018.

23 Bu ve burada değindiğimiz diğer Hayvanları Koruma Kanunları için, bkz. yuk. dn. no. 8.

24 Bolliger, Legal Protection, s. 370, dn. no. 439.
} 
fiziksel ve bilişsel niteliklerinden bağımsız olarak, kendi içsel değerleri nedeniyle korumayı amaçladıkları için biyosantrik bir yaklaşıma dayanmaktadırlar ${ }^{25}$.

Hayvanları kategorileştirme eğiliminin diğer ayağı, hayvanlara sağlanan korumayı, hayvanın insanlarla olan yakınlığına göre derecelere tabi tutma amacı üzerinde yükselmektedir ${ }^{26}$. Ev hayvanları en geniş korumadan yararlanmakta, sonraki sırayı çiftlik hayvanları almaktadır. Doğada serbest halde bulunan hayvanlar ise daha da farklı bir rejime tabidir; çünkü bunlar res nullius statüsündedir, yani üzerinde mülkiyet hakkı kurulabilen, ancak halihazırda mülkiyet altında olmayan varlıklardır ${ }^{27}$. Eğer korunan türler içinde değilse, bu hayvanlar ya avlanabilir hayvan statüsündedir, ki bu halde av zamanları ve kullanılabilecek silahlar yasal düzenlemeye tabi olabilir, ya da zararlı hayvan statüsündedir, ki bu halde yok edilmeleri mümkün olacaktır ${ }^{28}$. Bizim hukukumuzda da 5199 sayılı Hayvanları Koruma Kanunu'nun, kapsamına girecek hayvan kavramını genel olarak tanımlamadığını, hayvanların insanlarla olan ilişkileri ve gördükleri işlevlere göre belirli kategorilerin kendi içlerinde tanımlanmış olduğunu söylemek mümkündür. Kanunun "Tanımlar” başlıklı üçüncü maddesi, hayvanları evcil hayvan, sahipsiz hayvan, güçten düşmüş hayvan, yabani hayvan, ev ve süs hayvanı, kontrollü hayvan, deney hayvanı ve kesim hayvanı olarak sınıflara ayırmış ve her bir sınıf için farklı kurallar öngörmüştür ${ }^{29}$. Ayrıca, yine değişik ülkelerdeki düzenlemelere bakıldığında, belirli bir kategori içindeki hayvanlar için de çoğunlukla genel nitelikte ilkelerin konulmadığını, koruma normlarının hayvanların yetiştirilme koşulları, taşınmaları, öldürülmeleri, deneylerde kullanılmaları gibi belirli durumlara ilişkin olduğunu görmekteyiz ${ }^{30}$.

Bununla beraber bu kategorilerin, hayvanların korunması açısından kendi başına olumsuz bir duruma işaret ettiği de düşünülmemelidir. Kategoriler temel sorunları ayrıştırarak üzerlerinde çalışılmasını kolaylaştırıcı işlev görebilir. Örneğin vahşi hayvanların korunması, türlerin yok olmasıyla mücadele edilmesi, deney hayvanlarının korunması, alternatif deney metodları bulunması, sokak hayvanlarının korunması, onların menfaatleri ile kamu sağlığının gereklerinin uzlaştırılması üzerinde çalışılarak sağlanabilir ${ }^{31}$. Hayvanların korunması açısından bu noktada eleştiri götürebilecek husus, bu kategorilerin, hayvanların canlı varlık olarak sahip

\footnotetext{
${ }_{25}$ Idem, s. 355-356; Stucki, Die «tierliche Person», s. 294-295; bkz. aş. III-A-1-b.

26 Falaise, s. 7.

27 Turhan Esener / Kudret Güven, Eşya Hukuku, 7. Bası, Yetkin Yayınları, Ankara, 2017, s. 45; Epstein, s. 3.

28 Falaise, s. 7.

29 Kanunumuzdaki kategoriler için, bkz. Şeref Ertaş, Çevre Hukuku ve Hayvan Hakları Hukuku, 2. Bası, İleri Kültür Merkezi, İzmir, 2012 s. 475-476; Emre Cumalığlu, "Medeni Hukukta Hayvan Hakları ve Hayvanlar Üzerindeki Hak", Dokuz Eylül Üniversitesi Hukuk Fakültesi Dergisi, Prof. Dr. Şeref Ertaş'a Armağan, Özel Sayı, C. 19, 2017, s. 587-604.

30 Falaise, s. 2.

31 Nadege Reboul-Maupin, "Pour une rénovation de la summa divisio des personnes et des biens", Petites affiches, S. 259, 28.12.2016, para. no. 23. Bu kategorilerin hayvan onuru kavramının içeriğini belirlemekte de işlevsel olduğu yönünde, bkz. Elizabeth Loder, "Animal Dignity”, Animal Law Review, C. 24, 2016, s. 37 vd. Hayvan onuru kavramı için, bkz. aş. IIIA-1-b (iii).
} 
olabilecekleri ortak koruma alanlarının geliştirilmesi gereğinin geri planda kalmasına neden olacak şekilde kullanılmakta olmalarıdır ${ }^{32}$.

Hayvanları koruyucu normların bu parçalı yapısı ve esasında toplumlara göre değişebilen ahlaki temellere dayanıyor olması, hukukun uyumlulaştırılmasına ilişkin çabaların da sınırlı bir başarı sağlamasına neden olmaktadır. Bu alanda evrensel alanda atılan en önemli adım, 15 Ekim 1978 tarihinde UNESCO sarayında ilan edilen Hayvan Haklar1 Evrensel Bildirgesi (Universal Declaration of Animal Rights) olmuştur. Hukuki bağlayıcılık taşımayan ${ }^{33}$, ancak evrensellik iddiasındaki bazı değerleri belirleyen bildirge, hayvanlara, İnsan Hakları Evrensel Bildirgesi'nde (Universal Declaration of Human Rights) tanınanlara paralel nitelikte haklar tanımış ve insanoğlu için yeni bazı davranış kodları belirlemeye çalışmıştır ${ }^{34}$. Bildirge hayvan onuru kavramını (m. 10) gündeme getirmiş, hayvanın gereksiz olarak öldürülmesini yaşama karşı suç olarak (m. 11) vasıflandırmıştır. Koyduğu ilkeler çerçevesinde bildirge, insanın çevresine mutlak biçimde hükmettiği antroposantrik yaklaşımdan çıkarak yaşama saygı ilkesini esas alan yeni bir kültürü yansıtma çabası içindedir ${ }^{35}$. 1989 yılında metinde yapılan değişiklikler ${ }^{36}$ sonucu $^{2}$ bildirge, hayvanların hukuki kişiliğinin ve haklarının yasa tarafından tanınması

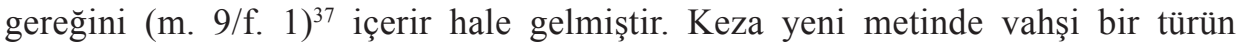
hayatta kalmasını tehlikeye atan eylemler ve bu eylemlerin işlenmesine sebep olan kararların soykırım, yani türe karşı suç sayılacağını belirtilmiştir (m. 8/f. 1) ${ }^{38}$. Ancak bildirge, bu genel ilkeleri koyarken bir yandan da, tıpk1 yerel koruma kanunlarında olduğu gibi, hayvanları farklı koruma düzeylerine tabi tutulabilecek şekilde çeşitli kategorilere ayırmıştır. Bu niteliği ile bildirge hem hayvan hakları savunucularını tatmin etmekten uzak kalmış, hem de hayvanlara bağımlı olarak işleyen ekonomik sektörlerin aktörlerince eleştirilere tabi tutulmuştur ${ }^{39}$. Benzer bir girişim Dünya Hayvanları Koruma Topluluğu (World Society for the Protection of Animals) $)^{40}$ tarafından yürütülmüş ve hazırlanan Hayvan Refahı Evrensel Bildirgesi (Universal

\footnotetext{
2 Bu kategorilerin fiilen hayvanların değil, insanların ihtiyaçlarına göre işlemekte olduğu yönünde, Michel, s. 620.

33 Anne-Blandine Caire, "Les animaux ont-ils des droits? L'animal, eternel atopos?" La Revue "Le droit des animaux", S 6, 2014, s. 8; Jean-Marc Neumann, "La Déclaration Universelle des Droits de l'Animal ou l'égalité des espèces face à la vie", in: Animal Law-Tier und Recht, Developments and Perspectives in the 21st Century, ed. Michel Margot/Kühne Daniela/ Hänni Julia, Zürih/St. Gallen, 2012, s. 382; bildirgenin etik bağlayıcılığı olduğu yönünde, Cumalığlu, s. 576.

34 Neumann, s. 363

35 Idem, s. 370

36 Idem, s. 378 vd. Yeni metnin taslağı Hayvan Hakları Evrensel Ligi’nin genel kurulunda hazırlanmış ve 21 Ekim 1989'da kabul edilmiștir.

37 Hükmün İngilizce metni "the specific legal status of animals and their rights must be recognised by law" (hayvanların özel hukuki statüsü ve hakları kanun tarafından tanınmalıdır) ifadesini, Fransızca metni ise "la personnalité juridique de l'animal et ses droits doivent être reconnus par la loi" (hayvanın hukuki kişiliği ve hakları kanun tarafından tanınmalıdır) ifadesini içermektedir. Böylece Fransızca metin açıkça hukuki kişilik kavramını kullanırken, İngilizce metinde "hayvanın özel hukuki statüsü” ifadesi kullanılmış olmaktadır.

38 Bu iki bildirgenin hükümleri hakkında, bkz. Tamer İnal, "Hayvanın Hukuki Kişiliğinin ve Haklarının Tanınması Gereği Üzerine", Kazancı Hukuk, İşletme ve Maliye Bilimleri Hakemli Dergisi, S. 1, 2004, s. 28 vd.

39 Neumann, s. 376- 377.

40 Topluluğun adı, 2014’te “World Animal Protection” olarak değişmiştir.
} 
Declaration on Animal Welfare) Birleşmiş Milletler tarafından desteklenme beklentisi ile ${ }^{41} 2011$ yılında kamuoyuna açıklanmıştır ${ }^{42}$. Hayvan Hakları Evrensel Bildirgesi'nden daha küçük adımlar içermesine, özellikle hayvanlara yeni bir hukuki statü tanınmasını değil, acı verici muamelenin azaltılmasını amaçlamış olmasına rağmen, bu girişim de beklenen başarıya ulaşamamıştır ${ }^{43}$. Esaslı bir perspektif değişikliğine yol açabilecek ortak ilkeler koyma yönündeki kararsızlık, kendisini Avrupa Birliği mevzuatı nezdinde de göstermiştir. 1 Aralık 2009'da yürürlüğe giren Lizbon Antlaşması hayvanları "duyarlı varlıklar" (sentient beings) olarak kabul etmiş, hayvanların korunmasını ve refahının sağlanmasını, birliğin politikalarının belirlenmesinde dikkate alınması gereken bir unsur olarak öngörmüş, ancak dini ibadetlerin yanında, kültürel geleneklere ve bölgesel mirasa da aynı şekilde saygı gösterilmesi gerektiğini belirterek, hayvan refahınının yine eğlence odaklı kültürel gelenekler gibi, bazıları esaslı ihtiyaçlar olarak görülemeyecek insan menfaatleri için feda edilebilmesi imkanını da dışlamamıştır.

Ortak ilkeler koyma yönündeki güçlüğe rağmen, belirli hayvan kategorileri açısından Avrupa ülkeleri nezdinde bazı bağlayıcı normlara ulaşılmış olduğu söylenebilir. 80'li yıllardan bu yana çeşitli alanlarda hayvanların kullanımına ilişkin düzenlemeler ihdas eden ${ }^{44}$ Avrupa Birliği nezdinde hayvanların taşınmasını, kesimini, çiftlik hayvanlarının, deney hayvanlarının, ev hayvanlarının kullanımını düzenleyen ve her bir kategori için refah şartlarını belirleyen kurallar ${ }^{45}$ ihdas edilmiştir ${ }^{46}$. Keza Avrupa Konseyi nezdinde de benzer alanlarda bazılarına ülkemizin de taraf olduğu antlaşmalar imzaya açılmıştır ${ }^{47}$. Bu düzenlemeler de hayvanları, yukarıda belirtildiği gibi kullanım amaçlarına göre kategorilere ayırmakta ve kullanım amacının elverdiği ölçüyle sınırlı da olsa empatik bir yaklaşımın hukuki plana yansımasını sağlamaya çalışmaktadır.

Uluslararası alanda ortak ilkeler koymakta yaşanan güçlükler, bazı ülkelerin bu alanda daha cesur adımlar atmasına engel olmamıştır. Hayvanların korunmasına ilişkin en önemli gelişmelerden biri, bazı ülkelerde bu korumanın yasal düzlemden anayasal

\footnotetext{
41 Gibson, s. 542.

42 Metin için bkz. https://www.globalanimallaw.org/database/universal.html, (E.T. 21.11.2018).

43 Gibson, s. 548.

44 Paola Sobbrio, "The Relationship between Humans and other Animals in European Animal Welfare Legislation", Relations. Beyond Anthropocentrism, C. 1, 2013, s. 34.

45 Donald M. Broom, "Animal Welfare in the European Union”, European Parliament, Policy Department for Citizens' Rights And Constitutional Affairs, 2017, http://www.europarl.europa.eu/RegData/etudes/STUD/2017/583114/IPOL STU(2017)583114 EN.pdf, (E.T. 21.11.2018) s. 24; bkz. Arıkan, s. 145 vd.

46 Avrupa Birliği’ndeki düzenlemelerin hayvan refahını sağlamaktan ziyade özellikle insan sağlığı açısından insan refahını sağlamaya yönelik oldukları yönünde, Sobbrio, s. 34 vd.

47 Avrupa Konseyi nezdindeki antlaşmalar için bkz. https://www.coe.int/t/e/legal affairs/legal co-operation/biological safety_and_use_of_animals/default.asp (E.T. 21.11.2018); uluslararası antlaşmalar hakkında ayrıca bkz. Arıkan, s. 187 vd.
} 
düzleme kaydırılmış olmasıdır ${ }^{48}$. İsviçre Anayasası'nın 80. ve 120. maddeleri ${ }^{49}$, Alman Anayasası'nın 20a maddesi ${ }^{50}$, Lüxembourg Anayasası'nın 11bis maddesi ${ }^{51}$ hayvanların korunmasını anayasal bir amaç olarak belirlemişlerdir ${ }^{52}$. Böylece yasama, yürütme ve yargı organlarına, kendi işlevlerini ifa ederken anayasal hayvanları koruma amacı çerçevesinde hareket etme yönünde bir direktif verilmiş olmaktadır ${ }^{53}$. Yasama organı, yasama faaliyetinde, yürütme organı içindeki birimler, örneğin, hayvanlara ilişkin olan ve izin alınmasını gerektiren aktivitelerde izin taleplerini değerlendirirken, keza yargı organı, bir hayvanın menfaatinin bir insan menfaatiyle çatışmaya girdiği uyuşmazlıklarda, hayvanları koruma amacının anayasal niteliğini dikkate almak zorundadır. Hayvanların korunmasının anayasal bir ilke olması, bir yandan, bu ilkeye aykırı işlemlerin anayasaya aykırılı̆ga bağlanan yaptırımlara tabi tutulabilmesini ${ }^{54}$, öte yandan, hayvanların menfaatlerinin, anayasa ile güvence altına alınan temel insan hak ve özgürlükleri ile çatışmaya girdiklerinde daha etkin biçimde dikkate alınabilmelerini sağlamaktadır. Gerçekten de, hayvanlara yapılan kötü muamelelerin insanların bilimsel, sanatsal, dinsel ve ekonomik alanlardaki, anayasa ile güvence altına alınmış temel hak ve özgürlüklere dayandırılması mümkündür ${ }^{55}$. Hayvanların menfaatlerinin yasal, insan haklarının anayasal düzlemde korunması, bu sonuncuların kategorik olarak hayvanların menfaatlerine üstün tutulmasına sebep olmaktadır. Hayvanların korunmasının anayasal düzeyde bir amaç halinde gelmiş olması, hayvanların menfaatlerinin insanlara tanınan temel hak ve özgürlüklerle aynı hiyerarşik düzeye taşınması anlamına gelmekte, böylece devlet organlarının, hayvan haklarının gelişimi için insan haklarına sınırlama getirebilmesine hukuki zemin kazandırılmaktadır ${ }^{56}$.

48 Anayasalarda daha yaygın olarak karşımıza çıkan, çevrenin korunmasına yönelik düzenlemeler, canlı hayatı bir bütün olarak ele almakta olup, hayvanların birey olarak korunmasını hedeflemezler. Oysa doğrudan doğruya hayvanların korunmasına yönelik düzenlemelerin özelliği, hayvanların çevrenin unsuru olarak değil, yaşayan bir varlık olarak, birer birey olarak görülmesinde yatmaktadır. Ayrım için bkz. Olivier Le Bot, "La protection de l'animal en droit constitutionnel. Etude de droit comparé", Lex Electronica, C. 12/2, 2007, s.3- 4

49 120. madde için, bkz. aşağıda III-A-1-b (iii).

50 26 Temmuz 2002 tarihli değişikliğe götüren sebepler için, bkz. Erin Evans, "Constitutional Inclusion of Animal Rights in Germany and Switzerland: How Did Animal Protection Become an Issue of National Importance?", Society and Animals, C. 18, 2010, s. 235 vd.; Sabine Lennkh, "The Animal: A Subject of Law? A Reflection on Aspects of the Austrian and German Juridical Systems", International Journal for the Semiotics of Law, C. 24, I. 3, 2011, s. 318.

51 Hükmün kabul süreci için bkz. Le Bot, Protection de l'animal, s. 13-15.

52 Çeşitli sosyo-kültürel gerekçelere dayalı olarak belirli hayvan türlerini korumayı amaçlayan anayasal normlar da bulunmaktadır. Bu düzenlemeler için bkz. Le Bot, Protection de l'animal, s. 6-8.

53 Claudia E. Haupt, "The Nature and Effects of Constitutional State Objectives: Assessing the German Basic Law's Animal Protection Clause", Animal Law Review, C. 16, 2010, s. 226; Le Bot, Protection de l'animal, s. 10; anayasal normun yasama faaliyeti ve hukuk kurallarının yorumlanması aşamasında etki doğurması gerektiği yönünde, Roman Kolar, "Three Years of Animal Welfare in the German Constitution-the Balance from an Animal Welfare Perspective", Altex C. 22, Özel Sayı 2, 2005, s. 147. Bu çerçevede, örneğin artık yasama organının üzerinde yasama işlemlerini en azından mevcut standardı düşürmeme yönünde bir görev bulunduğu ileri sürülmüştür; bkz. Haupt, s. 228; Lennkh, s. 319.

$54 \quad$ Le Bot, Protection de l'animal, s. 51.

55 Gieri Bolliger, “Animal Dignity Protection in Swiss Law-Status Quo and Future Perspectives”, Schriften zum Tier im Recht, No 15, 2016, s. 28; Olivier Le Bot, "Les Grandes Evolutions du Regime Juridique de l'Animal en Europe: Constitutionalisation et Dereification", Revue Quebecoise de Droit International, C. 24, 2011, s. 252.

56 Lennkh, s. 318; Kolar, s. 147; Le Bot, Protection de l'animal, s. 37; Bolliger, Animal Dignity s. 27; Michel, s. 615. Almanya'da anayasa değişikliğinden sonra yargı kararlarında hayvanlar lehine yaşanan gelişim için bkz. Kolar, s. 146148; Le Bot, Protection de l'animal, s. 30-32; Haupt, s. 237 vd.. Ancak yapılan değişikliğin Almanya'da özellikle hayvan deneyleri alanında etik komitelerin işleyişinde yetersiz kaldığ 1 yönünde, Kolar, s. 148-149. 
Sonuç olarak görülmektedir ki, anayasal seviyedeki gelişmeler bir yana bırakılırsa, hayvanların korunmasını amaçlayan hukuk kurallarının gelişimi, radikal değişikliklerle değil, farklı alanlardaki pragmatik çözümlerin birikmesi yoluyla gerçekleşmektedir. ${ }^{57}$ Bugün ulaşılan noktada kabul gören ortak payda, ancak çağdaş toplumların büyük kısmı tarafından sadistlik olarak görülebilecek eziyetlerin önünde geçilmesi yönündedir. Duyarlı olduğu kabul edilen hayvan türlerinin "gereksiz" biçimde acı çekmesinin ötesinde yer alan menfaatlerinin korunması noktasına gelindiğinde, hukuki normların, her bir toplumun kendi ihtiyaçlarına ve değer yargılarına göre farklı yönlere doğru evrilmekte olduğunu görmekteyiz ${ }^{58}$. Bu evrim yer yer hayvanın hukuken kişi olması gerektiği iddiasına kadar götürmüştür.

\section{Hayvanları Koruma Normlarının Kişi ve Eşya Ayrımına Etkisi}

Hukuk sistemleri, Roma hukukundan geldiği kabul edilen bir anlayışa bağlı olarak ${ }^{59}$, varlıkları özne veya nesne, başka bir deyişle kişi ve eşya olarak sınıflandırmaktadır ${ }^{60}$. Kişiler, hak sahibi olanları ${ }^{61}$, hakların öznesini, eşyalar ise hakların konusunu teşkil etmektedir ${ }^{62}$. Kişi kavramı ise, gerçek kişiler ile tüzel kişiler olarak bilinen ikili bir ayrım içinde şekillenmiştir. Ne gerçek kişi ne de tüzel kişi olan hayvanlar da, insanların onlar üzerinde kurageldiği egemenlik ile paralel olarak, eşya olarak konumlandırılmış ${ }^{63}$, böylece hak öznesi olabilme imkanları dışlanmıştır.

Hayvanlarla ilişkilerimiz konusundaki kültürel gelişmelerin hukuki plandaki etkisi de tam da bu noktada kendini göstermektedir. Hayvanların birer canlı varlık oldukları

\footnotetext{
57 Falaise, s. 2.
}

58 Faaliyetleri hayvan kullanımına dayalı mesleki gruplarının bu alandaki kanunların düzenlenmesinde yürüttükleri lobicilik faaliyetlerinin etkisine ilişkin olarak, bkz. Neumann, s. 386.

59 Favre, s. 1024. Kişi ve eşya ayrımının net olarak Gaius'un Institutes eserinde bulunduğu yönünde, John R. Trahan, "The Distinction Between Persons \& Things: An Historical Perspective", Journal of Civil Law Studies, C. 1, 2008, s. 9; Visa Kurki, "Animals, Slaves, and Corporations: Analyzing Legal Thinghood", German Law Journal, C. 18, S. 5, 2017, s. 1072. Ancak bu yazar, Roma hukukunda bu ayrımın içeriğinin bugünkü kadar net ve dışlayıcı biçimde belirlenmemiş olduğunu, örneğin kölelerden hem eşya hem de kişi sınıfları altında bahsedilmiş olduğunu savunmakta ve her varlığın ya kişi ya da eşya olacağı önermesini eleștirmektedir (s. 1072 vd). Benzer bir görüș için, bkz. Emmanuel Lazayrat / Judith Rochfeld / JeanPierre Marguénaud, "La distinction des personnes et des choses", Droit de la famille, S. 4, 2013, Etude 5, para. no. 8-11.

${ }^{60}$ İsviçre hukuku için, bkz. Stucki, Rechtstheoretische Reflexionen, s. 145; Paul-Henri Steinauer, "Tertium datur?", in Figures juridiques, Mélanges dissociés pour Pierre Tercier à l'occasion de son soixantième anniversaire, ed. Gauch Peter/ Pichonnaz Pascal, Cenevre/Zürih/ Basel, 2003, s. 52; Heinz Rey, Die Grundlagen des Sachenrechts und das Eigentum, Stämpfli Verlag AG, Bern, 2007, s. 41. Fransız hukuku için, bkz. Reboul-Maupin, s. 6.; Manuel Carius, "Quel statut juridique pour le cheval?", Revue de droit rural, 2014, no 425, para. no. 9. Amerikan hukukunda da aynı ayrımın cari olduğu yönünde, Jessica Berg, "Of Elephants and Embryos: A Proposed Framework for Legal Personhood", Hastings Law Journal, C. 59, 2007, s. 372; hayvanların sadece insanların mülkiyet hakkının konusu olarak görüldüğ̈̈ yönünde, Bradshaw, s. 818.

${ }_{61}$ Kurki, s. 1079; Rona Serozan, Medeni Hukuk-Genel Bölüm/ Kişiler Hukuku, 7. Bası, Vedat Kitabevi, İstanbul, 2017, s. 199; kişinin hak ehliyetine sahip olan varlık olduğu yönünde, Serap Helvacı/Fulya Erlüle, Medeni Hukuk, 5. Bası, Legal Yayıncilık, 2018, s. 56.

62 Christina Stresemann, BGB § 90a, Münchener Kommentar zum Bürgerlichen Gesetzbuch, Band 1: Allgemeiner Teil §§ 1-240, 7. Bas1, C.H. Beck, 2015, para. no. 3; Steinauer, Tertium datur, s. 52.

63 Stucki, Rechtstheoretische Reflexionen, s. 145; Margot Michel / Eveline Schneider Kayasseh, "The legal situation of animals in Switzerland: Two steps forward, one step back - many steps to go", Journal of Animal Law, C. 7, 2011, s. 20; Wolfgang Wiegand, Art. 641a, Zivilgesetzbuch II, Basler Kommentar, ed. Honsell, Heinrich/Vogt, Nedim Peter/Geiser, Thomas, 5. Bas1., Helbing Lichtenhahn Verlag, 2015, s. 894. 
yönündeki bilinç geliştikçe insanların hayvanlar üzerindeki egemenliğine hukuk kuralları ile gittikçe artan biçimde sınırlar çizilmiştir. Bununla beraber hayvanlar halen mülkiyet hakkının konusu olmaya da devam etmektedir. Hayvanları hem bazı hakların konusu, hem de bazı ödevlerin yararlanıcısı olarak konumlandıran kurallar bütününün, hayvanlara eşya-kişi ayrımı tahtında yeni bir hukuki statü kazandırıp kazandırmadığı da böylece tartışma konusu haline gelmiştir. Keza, pozitif hukukta karşımıza çıkan tablonun ne şekilde okunacağının yanı sıra, hayvanların hukuki statüsünün de lege feranda ne yöne evrilmesi gerektiği konusu da farklı görüşlere yol açmışırı. Bu çerçevede, hayvanları hakkın konusu veya hakkın öznesi olarak konumlandırma konusunda yapılan tercihe göre, hayvanların, yaşayan eşya, kendine özgü eşya, kısmi hukuk öznesi, ve hatta kişi olarak nitelendirilmesi gerektiği yönünde görüşler ileri sürülmüştür ${ }^{64}$. Bu görüşler çerçevesinde hayvanların hukuki statüsüne ilişkin çözüm yollarının irdelenmesi için (B) öncelikle çağdaş hukuk sistemlerinde hayvanları eşyalardan ayıran kurallardan öne çıkanlara değinilmesi gerekir (A).

\section{A. Hayvanları Eşya Olmaktan Uzaklaştıran Kurallar}

Hayvanların eşya olarak nitelendirilmesi ${ }^{65}$, onları başta mülkiyet hakkı olmak üzere ayni hakların konusu haline getirebilmemizi sağlamakta ${ }^{66}$ ve mülkiyet hakkının edinilmesi, korunması ve icrasına ilişkin sonuçların doğmasına neden olmaktadır. Eşya olmaları nedeniyle hayvanlar üzerinde, kanunlarda belirtilen çeşitli yollarla mülkiyet hakkı kurulabilmektedir. Herhangi bir kişinin egemenliğine tabi olmadan yaşamakta olan hayvanlar açısından sahipsiz eşya (res nullius) statüsü sahiplenme yoluyla mülkiyet hakkın kurulmasını mümkün kılmaktadır ${ }^{67}$. Hakkın korunmas1, üçüncü kişilerin hayvana zarar veren eyleminin hayvanın malikinin malvarlığ hakkına zarar verilmesi olarak tasnif edilmesi ve fail için haksız fille dayalı tazminat sorumluluğu doğması yoluyla gerçekleşir. Hayvanın mülkiyet hakkının konusu olmasının bir diğer sonucu ise malikin mülkiyet hakkına bağlı yetkilerini hayvan üzerinde kullanabilmesidir. Dolayısıyla eşya nitelendirmesi mutlak biçimde kabul edilirse hayvanın kullanılması (usus), semerelerinden yararlanılması (fructus),

64 Bkz. aş. III-B.

65 Eşya kavramı, "maddi varlığı olan, üzerinde hakimiyet kurmaya elverişli, insan dışı, sınırlanabilen, iktisadi değer taşıyan herşey" olarak tanımlanmaktadır: Şeref Ertaş, Eşya Hukuku, 13. Bası, Fakülteler Barış Kitabevi, İzmir 2017, s. 6; ayrıca bkz. Esener/Güven, s. 41; M. Kemal Oğuzman/Özer Seliçi/Saibe Oktay-Özdemir, Eşya Hukuku, 20. Bası, Filiz Kitabevi, İstanbul, 2017, s. 4 vd.; O. Gökhan Antalya, Eşya Hukuku, Cilt 1, Legal Yayıncılık, İstanbul, 2017, s. 15 vd. Konu için genel olarak bkz. Sanem Aksoy Dursun, Eşya Kavramı, Oniki Levha Yayıncılık, İstanbul, 2012 s. 5 vd.

${ }^{66}$ Le Bot, Grandes evolutions, s. 254. Bu durum, ortaçağda yoğunluk kazanan ve 20. yüzyıla kadar yer yer devam ettiği bilinen, hayvanların mahkemelerde taraf olarak yargılanması uygulaması çerçevesinde de değişmemiştir (Kelch, Part I, s. 45 vd.). Ortaçağda hayvanlar, ürünlere zarar vermek gibi bir zarara yol açıyorlarsa eklesiyastik mahkemelerde, insanlara zarar vermeleri halinde seküler mahkemelerde yargılanıyor, insanların yargılanmasında geçerli olan kurallar uygulanıyor, hayvanlara savunma avukatı atanıyordu. Suçlu bulunan hayvanların infaz aşamasında insan gibi giydirildiklerine ilişkin veriler de bulunmaktadır. Hayvanları kişi olarak görmeyen, irade sahibi olduklarını da varsaymayan sistemlerde bu tür bir uygulamanın yerleşmiş olması dini sebeplere bağlanmaktadır. Hayvanların düzene aykırı davranışlarının ilahi düzeni bozduğu ve tanrısal adaletin sağlanması için yargılamanın bir ritüel çerçevesinde yapıldığı belirtilmektedir (Kelch, Part I, s. 50 vd.).

${ }^{67}$ Sahiplenme ile doğadaki sahipsiz hayvanlar üzerinde taşınır mülkiyetinin kazanılması hakkında bkz. Ertaş, Eşya Hukuku, s. 491; Esener/Güven, s. 347; Oğuzman/ Seliçi/ Oktay-Özdemir, s. 755. 
satılması, terk edilmesi veya yok edilmesi gibi maddi veya hukuki bir tasarrufla malvarlığından çıkarılması (abusus) da mümkün olmalıdır ${ }^{68}$.

Ancak, bu kuralların hayvanlar üzerinde mutlak olarak uygulanması rahatsız edici sonuçlara yol açabilir. Doğada sahipsiz olan her hayvanın sınırsız biçimde mülkiyet konusu yapılabilmesi bazı hayvan türlerinin sonunun gelmesini ve yaşadığımız çevrenin genel olarak zarar görmesini tetikleyecektir. Mülkiyet konusu olan bir hayvana verilen zarar nedeniyle malike sağlanan korumanın eşya nitelendirmesine göre değerlendirilmesi, tazminat sorumluluğunun zarar gören hayvanın ekonomik değeri ile sınırlı olması sonucunu doğurabilir. Mülkiyet hakkının icrası çerçevesinde de eşya nitelendirmesi bizi kolaylıkla kabul edemeyeceğimiz sonuçlara götürecektir: Hayvanların malikleri tarafından keyfi olarak terk edilmeleri veya öldürülmeleri, mülkiyet hakkına dayanarak kolaylıkla benimseyebileceğimiz haller değildir. Hayvanların canlı varlık olma niteliklerini dikkate alan bazı hukuk sistemleri, eşya nitelendirmesine bağlı bazı sonuçların bu varlıklar üzerinde doğmasına engel olmak amacıyla özel kurallar yürürlüğe koymuş ve ilgili kuralların kapsamına giren hayvanları, alelade eşya olmaktan uzaklaştırmıştır $(1)^{69}$. Bizim hukukumuz bu açıdan daha yavaş bir gelişme izlemektedir. Bununla beraber hukukumuzda da insanın hayvanlar üzerindeki egemenliğinin cansız varlıklar üzerinde olduğu kadar sınırsız olmadığı, mülkiyet hakkına yer yer getirilen sınırlamalardan ortaya çıkmaktadır (2).

\section{Yabancı Hukuk Sistemlerinden Örnekler}

Hayvanları diğer eşyalardan farklı kurallara tabi tutan düzenlemeler ve yarg1 kararlarından bazıları, canlı bir varlık olarak hayvanı korumaktan ziyade, sahip olduğu hayvan ile geliştirdiği özel bağdan ötürü sahibini korumak amacını gütmektedir. $\mathrm{Bu}$ durumda hayvanın korunması, ancak bir yansıma sonuç olarak karşımıza çıkmaktadır (a). Diğer bazı kurallar ise, doğrudan doğruya hayvanların kendilerine ait menfaatlerini, insanlara karşı korumayı amaçlamaktadır (b).

\section{a. Hayvanların Malikleri İçin Korunmaları}

\section{(i) Hayvanlara verilen zararın tazmini}

İsviçre hukuku. İsviçre'de 2002 yılında getirilen değişikliklerden ${ }^{70}$ ikisi, İsviçre Borçlar Kanunu’nun 42. ve 43. maddelerine ilişkindir. Kanun koyucu, “ev ortamında

\footnotetext{
8 Mülkiyet hakkından doğan bu yetkilerin içeriği için bkz. Ertaş, Eşya Hukuku, s. 212; Esener/Güven, s. 179; Oğuzman/ Seliçi/ Oktay-Özdemir, s. 274.

69 Toplu norm değişikliği yaratan kanunlar için, bkz. yuk. dn. no. 7.

70 Bkz. yuk. dn. no. 7. Bu kanun ile yapılan değişikliklerin toplu olarak değerlendirilmesi için bkz. Arzu Genç Arıdemir, "Hayvanların Hukuki Konumlarının İyileştirilmesi Amacıyla İsviçre Medeni Kanunu ile Borçlar Kanunu’nda Yapılan Değişikliklere Genel Bir Bakış”, Prof. Dr. Hüseyin Hatemi’ye Armağan, Cilt-1, Vedat Kitapçılık, İstanbul 2009, s. 327 vd. Kanunun kabul süreci için bkz. Steinauer, Tertium datur, 52 vd.
} 
yaşayan ve kazanç amacı ya da maddi bir amaç güdülmeden tutulan" "71 hayvanların yaralanması veya ölümü halinde failin sorumlu olacağı tazminat miktarı için, biri maddi zarar, diğeri manevi zarara ilişkin iki özel düzenleme getirmiştir. Haksız fiilden doğan zararın miktarının tespitini konu alan 42. maddeye eklenen 3. fikraya göre, bu tür bir hayvanın tedavisi için yapılması gereken masraf, hayvanın değerinden yüksek olsa dahi, hakim tarafından uygun bir ödeme miktarı belirlenecektir. Failin, zarar gören hayvanın değerini aşan bir miktarla sorumlu tutulabilmesi ${ }^{72}$, eşyanın onarım değerinin (tedavi masrafının) değişim değerini aşmaması gerektiği yönündeki tazminat hukuku kuralından bir sapma teşkil etmektedir ${ }^{73}$. Haksız fiil failinin ödemekle yükümlü olduğu tazminat miktarının tayinini konu alan 43. maddede yapılan değişiklik ise, yine ev ortamında yaşayan ve kazanç amacı ya da maddi bir amaç güdülmeden tutulan bir hayvanın yaralanması veya ölmesi halinde, hakimin, tazminat miktarını tayin ederken, hayvanın, onu bulunduran veya yakınları için taşıdığı duygusal değeri uygun bir ölçüde dikkate alabileceğini öngörmektedir. Görüldüğü gibi hüküm, hayvanın belirli insanlar için taşıdığı manevi değeri, zedelenmesi halinde tazminat talebini haklı gösterebilecek bir değer olarak tanımlamış olmaktadır. Ancak belirtilmelidir ki bu hükmün yerindeliği ve diğer hükümlerle ilişkisi öğretide farklı görüşlere yol açmıştır. Tartışılan noktalardan biri, hükmün kişilik hakkının zedelenmesinden doğan manevi zararın tazminini düzenleyen ve tazminat sorumluluğunu ağır ihlal şartına bağlayan 49. madde ile olan ilişkisidir. Bazı yazarlar, hayvan ile olan duygusal bağın da kişilik hakkının parçası olduğu düşüncesinden hareketle, hayvanın ölümünden doğan manevi zararın tazmininin de ancak 49. madde çerçevesinde ve burada öngörülen ihlalin ağırlığı (gravité de l'atteinte) şartının yerine gelmesi şartıyla talep edilmesi gerektiğini savunmuştur ${ }^{74}$. Bazı yazarlar ise 43. maddeye getirilen yeni hükmün, 49. maddenin ağır ihlal şartı nedeniyle tazminine imkan vermediği bir manevi zararın tazminini sağladığı fikrindedirler ${ }^{75}$. Bu görüş çerçevesinde, 43. maddede ihlalin ağırlığı şartını aramayan kanun koyucunun amacının, hayvanın

71 Fransizca metin "les animaux qui vivent en milieu domestique et ne sont pas gardés dans un but patrimonial ou de gain" ifadesini kullanmaktadır.

${ }^{72}$ Christine Chappuis, "Les nouvelles dispositions de responsabilité civile sur les animaux : que vaut Médor?”, in: Le préjudice : une notion en devenir : Journée de la responsabilité civile 2004, ed. Chappuis Christine/Winiger Bénédict, Schulthess, Cenevre, 2005, s. 22 vd.; Michel/ Schneider Kayasseh, s. 22; Hüseyin Can Aksoy, "Türk ve İsviçre Hukuklarında Evcil Hayvanlara Verilen Zararlara İlişkin Özel Hukuktan Doğan Sorumluluk”, Türkiye Barolar Birliği Dergisi, S. 129, 2017, s. 162 vd.

73 Michel/ Schneider Kayasseh, s. 21, 23. Ancak gerekçede, bir eşyanın değerini aşan miktarda tazminat ödenmesinin pozitif hukukta dışlanmış olmamakla beraber, hayvanlara ilişkin olarak hukuk güvenliğini sağlamak adına bu açıklığın getirildiği ifade edilmiştir (bkz. Komisyon Raporu, s. 3892-3893). Keza, bu kuralın herhangi bir eşyaya da istisnai hallerde uygulanmasının öğretide çoktandır kabul edildiği, dolayısıyla getirilen kuralın hayvanın özel statüsüne bağlı olmadığı yönünde, bkz. Steinauer, Tertium datur, s. 59.

74 Roland Brehm, "Les nouveaux droits du détenteur en cas de lésion subie par son animal (art. 42 al. 3 et 43 al. 1bis CO)", Responsabilité et assurance, 2003, s. 121 vd.; Guy Chappuis, "Les nouveaux droits du détenteur de l'animal tué ou blessé. Nouveaux, vraiment?", Responsabilité et Assurance, 2004, s. 93 vd.

75 Franz Werro, "Le tort moral, le contrat et la perte d'une chose", in: Une empreinte sur le Code Civil Mélanges en l'honneur de Paul-Henri Steinauer, ed. Rumo-Jungo Alexandra/ Pichonnaz Pascal/ Hürlimann-Kaup Bettina/ Fountoulakis Christiana, Stämpfli 2013, s. 857-859. İBK m. 43’ün diğer manevi tazminat düzenlemelerinden farklı bir hüküm olduğu ve bu maddeler gerekçe gösterilerek yeni hükmün içinin boşaltılmasının kabul edilemez olduğu yönünde, bkz. Aksoy, s. 185. İlgili hükmün İBK m. 47 ve m. 49 ile ilişkisi hakkındaki görüşler için bkz. Aksoy, s. 176-180. 
taşıdığı duygusal değerin zedelenmesini ${ }^{76}$ başlı başına manevi zarar kalemi olarak nitelendirmek olduğ $\mathrm{u}^{77}$ belirtilmektedir. Hükümle ilgili olarak tartışılmış bir diğer nokta ise, hükmün hayvanın tedavi masrafına ilişkin 42. madde ile olan ilişkisi olmuştur. Hayvanın yaralanması halinde, 42. madde uyarınca, değerini aşan tedavi masrafi ile birlikte 43. madde uyarınca hayvanın duygusal değerine tekabül eden ilave bir tazminata ayrıca hükmedilebilecek midir? ${ }^{78} \mathrm{Bu}$ konuda da bazı yazarlar, hükümlerden birinin maddi bir zarara, diğerinin ise manevi zarara ilişkin olduğunu ve kümülatif olarak uygulanabileceklerini savunurken ${ }^{79}$, diğer yazarlar, 42. madde uyarınca istenecek ve tedavi masraflarını aşabilecek tazminatın, hayvanın duygusal değerini de içereceği, bu nedenle 43. madde uyarınca ayrıca tazminat istenmesine engel olacağını ifade etmişlerdir ${ }^{80}$.

Belirtilmelidir ki, her iki hüküm de sadece hayvanları diğer eşyalardan ayrıştırmaları açısından değil, aynı zamanda tazminat hukukuna getirdikleri yenilikler itibariyle de öğretide ilgi ile karşılanmıştır. Hayvanın tedavi masrafını hayvanın değerinden bağımsızlaştıran 42. madde hükmü maddi zararın hesaplanış biçimini fark teorisinin dışına çıkarmakta ${ }^{81}, 43$. madde ise, en azından bu hükme bağımsız bir etki tanıyan yazarlara göre, İsviçre hukukunda çekince ile karşılanan manevi zarar kavramının genişlemesine neden olmaktadır ${ }^{82}$.

Her iki hüküm açısından da üzerinde durulması gereken bir diğer husus, yapılan değişikliklerin ev ortamında yaşayan ve kazanç amacı ya da maddi bir amaç güdülmeden tutulan hayvanlara ilişkin olmalarıdır. Bu durum, hukuken değer gören unsurun hayvanın kendi menfaatleri değil, insanın hayvanla geliştirdiği ilişki olduğunu göstermektedir $^{83}$. Ev ortamında yaşama kıstasının yarattığı güçlükler karşısında, İsviçre Federal Mahkemesi, hükmün amacının insanın hayvanla olan duygusal ilişkisini dikkate almak ve hayvanı artık bir eşya gibi değerlendirmemek olmasından hareketle, hükmün hayvanla mekansal değil, duygusal yakınlığa göre yorumlanması gerektiği sonucuna varmıştı1 ${ }^{84}$. Öte yandan, hayvanın bulundurulmasının ekonomik bir

\footnotetext{
${ }_{6}$ Bu zararın tazmini için elbette zarar verilen hayvanın, davacı açısından taşıdığı manevi değer ortaya konulmalıdır. Dikkate alınabilecek ölçütler için, bkz. Michel/ Schneider Kayasseh, s. 25.

77 Werro, s. 859.

78 Bu konudaki değişik görüşler için, bkz. C. Chappuis, s. 27 vd.

79 Brehm, s. 120-121.

G. Chappuis, s. 96.

C. Chappuis, s. 32-33.

2 Werro, s. 859.

83 Steinauer, Tertium datur, s. 59

84 İsviçre Federal Mahkemesi, 1. Hukuk Dairesi, 19 Eylül 2017, 4A_241/2016. Aynı doğrultuda, hükmün dar yorumlanmamas gerektiği yönünde, bkz. Bkz. Christoph Müller, Analyse de l'arrêt Tribunal fédéral 4A 241/2016 du 19 septembre 2017, Responsabilité et assurance, 2017, s. 45-46; C. Chappuis, s. 20, Michel/ Schneider Kayasseh, s. 22. Ayn1 kavram 2002'de getirilen değişikliklerin önemli bir kısmında kullanıldığı için mahkemenin getirdiği yorum tüm bu hükümlerin işleyişin tespit etmek açısından önem taşımaktadır (Ortak mülkiyetin sona erdirilmesi için IMK m. 651a, bulunmuş hayvanların mülkiyetinin kazanılması için İMK m. 722, kazandırıcı zamanaşımı için İMK m. 728, haczedilemeyen eşyalar için İİK m. 92). 2002 revizyonunda ilgili hayvan kategorisini ev hayvanları ile sınırlandırmayan tek hüküm, mirasbırakanın yükleme yaratmasına ilişkin IMK'nın 482. maddesi olmuştur (bkz. aş. III-A-1-b-iv).
} 
sebebe de dayanmaması gerekmektedir. Satılmak için, etini veya ürünlerini tüketmek için, çalışma gücünden yararlanmak için veya herhangi bir şekilde gelir getirdikleri için bulundurulan hayvanlar bu düzenlemelerin kapsamına girmemektedir ${ }^{85}$. Hayvan, sahibi için ikili bir işlev üstleniyorsa, duygusal ilişkinin hayvanın ekonomik işlevinden baskın görüldüğü hallerde de ilgili hükümlerin uygulanabileceğ ${ }^{86}{ }^{86}$ abul edilmektedir. Temel ölçütün, insan ile olan duygusal ilişki olması, tazminat talep edebilecek kişi çevresinin de bu amaç çerçevesinde çizilmesine neden olmuştur: Kanun hak sahibi olarak sadece hayvan üzerinde mülkiyet hakkı olan kişiyi değil, hayvanı bulunduran kişiyi ve bunların yakınlarını da saymışıır ${ }^{87}$.

Alman hukuku. İsviçre Borçlar Kanunu'nun 42. maddesine benzer bir hükmü Alman Medeni Kanunu da ihtiva etmektedir. BGB § 251/2 uyarınca, verdiği zararı tazminle yükümlü olan kişi, zararın aynen tazmininin orantısız masrafa yol açacak olması halinde zararı nakden tazmin edebilir. Hükme 20.08.1990 tarihli kanunla eklenen $^{88}$ ikinci cümle ise, bir hayvanın tedavisi için yapılan masrafın hayvanın değerini önemli ölçüde aşmasının masrafın orantısız olarak kabul edilmesini sağlayamayacağını öngörmektedir ${ }^{89}$. Böylece, İsviçre'de yapılan düzenlemeye benzer şekilde, tedavi masrafının hayvanın değerini aşsa dahi tazmin edilebileceği kabul edilmiş ve tazmin edilebilir masrafın üst limitini eşyanın değeri olarak tesis eden genel kuraldan ayrılınması sağlanmıştır ${ }^{90}$. Bu hükmün, hayvanın malikinin hayvan ile kurduğu duygusal bağa ilişkin menfaatini korumayı amaçladığı kabul edilmektedir ${ }^{91}$. Bununla beraber, İsviçre düzenlemesinden farklı olarak hükmün uygulama alanının belirli bir hayvan kategorisine hasredilmemiș olması, hükmün ev hayvanlarının yanı sıra ekonomik kullanım amaçlı olarak tutulan hayvanlara, örneğin çiftlik hayvanlarına da uygulanabileceği fikrinin savunulmasına neden olmuştur ${ }^{92}$. Hayvanın ölümü veya yaralanması halinde sahibinin duygusal menfaatlerinin tazmini açısından ise Alman hukukunda özel bir düzenleme yapılmamış olduğunu görmekteyiz. Hayvan, mülkiyet hakkının konusu olarak nitelendirilmiş olduğundan, bir kişinin mülkiyet hakkına zarar verilmiş olması ise kanunda manevi tazminat

\footnotetext{
85 Brehm, s. 120.

86 Ibid

87 Michel/ Schneider Kayasseh, s. 24 ; buradaki hayvan bulunduran kavramının IBKK m. 56 (TBK m. 67) hükmündeki hayvan bulunduran ile aynı olması gerektiği yönünde, bkz. Brehm, s. 122; Aksoy, s. 181.

88 Bkz. yuk. dn. no. 7.

89 Masrafın orantılı olup olmadığının değerlendirilmesinde kullanılabilecek ölçütler için, bkz. Hartmut Oetker, BGB § 251, Münchener Kommentar zum BGB, ed. Sacker Franz Jürgen/Rixecker Roland/Oetker Hartmut/Limperg Bettina, 7. Bası, C.H. Beck, Münih, 2016, para. no. 61 vd.

90 Lennkh, s. 314; Johannes W. Flume, BGB § 251, BeckOK BGB, ed. Bamberger Heinz George/Roth Herbert/Hau Wolfgang/Poseck Roman, 47. Bas1, C.H. Beck, Münih, 2018, para. no. 26. Ancak bkz. Oetker, para. no. 52-53: Yazar hükmün ihdasından önce de hayvanların tedavi masraflarının tazmininin maddi değerleriyle sınırlandırılmış olmadığını, hükmün getirilmiş olmasının, özellikle yargı kararlarında tutarlılığı sağlamak için, sadece açıklık kazandırıcı nitelikte olduğunu ifade etmektedir.

$91 \quad$ Flume, para. no 28; Oetker, para. no. 56.

92 Lennkh, s. 314, dn. 24; Flume, para. no. 28; kanunun amacının sahibinin hayvanıyla olan duygusal bağlarını korumak olduğu ve bu nedenle sadece sadece ev hayvanlarına uygulanması gerektiği yönünde, bkz. Oetker, para. no. 56.
} 
alacağı doğuran haller arasında sayılmış olmadığından ${ }^{93}$, hayvana verilen zararın sahibi lehine tazminat alacağı doğurmadığı kabul edilmektedir ${ }^{94}$. Bu açıdan Alman hukukunda hayvanlar, diğer eşyalarla aynı kadere tabi tutulmuş olmaktadır ${ }^{95}$.

Fransız hukuku. Fransız hukukunda üçüncü kişinin haksız fiil sonucu hayvana zarar vermesi halinde malikin talep edebileceği tazminat ile ilgili olarak özel bir uygulama içtihat yoluyla geliştirilmiştir. Bu konuda bir ilk teşkil eden karar Lunus adlı bir yarış atının ölümüne ilişkindir. Lunus, yarışlara katılmak için geçici olarak tutulduğu mekandaki lambayı 1sırarak elektrik çarpması sonucu olarak ölmüş, hayvanın sahibi mekanın sorumlusundan tazminat talebinde bulunmuştur. Kararda temyiz mahkemesi, bir hayvanın ölümünün, maliki için oluşan maddi zarardan bağımsız olarak tazmini mümkün olan duygusal bir zarara yol açabileceğini belirtmiş, hayvanın satım bedelinden bağımsız olarak malike manevi tazminat ödenmesi gerektiğine hükmetmiştir ${ }^{96}$. Başka bir kararında temyiz mahkemesi bir veterineri tedavi uygulamayı reddetmesi sonucu ölen köpeğin sahiplerinin manevi zararlarının tazminine mahkum eden mahkeme kararını onamıştır ${ }^{97}$. Bugün bu yaklaşımın yerleşik bir içtihat halini aldığı kabul edilmektedir ${ }^{98}$.

\section{(ii) Hayvanların haczedilmeleri}

Bazı hayvanların haciz kapsamı dışında tutulması, hukuk sistemlerinin öteden beri benimsediği bir çözümdür. Ancak bu geleneksel çözümde söz konusu olan, borçlunun yaşamını hayvanlara bağımlı olarak idame ettirmesi halinde borçlunun asgari geçimi için ihtiyacı olan, ekonomik anlam taşıyan hayvanların haczinin engellenmesidir. $\mathrm{Bu}$ alanda son zamanlarda gözlenen eğilim ise, ekonomik değer taşımayan hayvanları da haciz kapsamı dışında tutmak yönündedir. İsviçre İcra ve İflas Kanunu'nun ( $L o i$ fédérale sur la poursuite pour dettes et la faillite) 92. maddesinde yapılan değişiklik ile ev ortamında yaşayan ve kazanç amacı ya da maddi bir amaç güdülmeden tutulan hayvanlar haczi mümkün olmayan eşyalar arasına alınmıştır. Gerek haczi engellenen hayvanların belirli bir kullanım amacına hasredilmiş olmaları, gerekse yapılan değişikliğin gerekçesinin, hayvanların insanlar için taşıdığı manevi öneme vurgu yapmas1 ${ }^{99}$, burada da yapılan düzenlemenin hayvanları korumayı değil, insanın

\footnotetext{
93 Bkz. BGB $\S 253 / 2$.
}

94 Oetker, para. no. 55 .

95 Avustuya hukukunda ise ABGB § 1331, bir eşyaya zarar verilmesi halinde, bazı özel şartların da gerçekleşmesi koşuluyla eşyanın maddi değerinin yanında maliki için taşıdığı manevi değere verilen zararın tazminini de sağlamaktadır ve hayvanlar için de uygulanabilir.

96 1. Hukuk Dairesi, 16 Ocak 1962, Bülten no 33.

97 1. Hukuk Dairesi, 27 Ocak 1982, Esas no 80-15947.

98 Alain Roy, “Papa, Maman, Bebe et Fido: L'Animal de Compagnie en Droit Civil ou L'Emergence d'un Nouveau Sujet de Droit”, Canadian Bar Review, C. 82, 2003, s. 806; Philippe Malaurie/Laurent Aynes/Philippe Stoffel-Munck, Droit des Obligations, 9. Bas1, LGDJ, Paris 2017, s. 154.

99 “On se rend compte de plus en plus aujourd'hui de l'importance que l'animal peut avoir pour les personnes seules, par exemple pour celles qui se trouvent dans un home ou pour des personnes souffrant de toutes sortes d'affections. Interdire expressément leur saisie clarifie la situation sur le plan juridique, même si les animaux de compagnie sont dans la pratique 
manevi menfaatlerini korumayı amaçladığını göstermektedir ${ }^{100}$. Fransız İcra Usulleri Kanunu'nun (Code des procédures civiles d'exécution) R. 112-2. maddesi de benzer şekilde, borçlunun hayatını devam ettirmesi için zorunlu olan hayvanlar dışında, ev hayvanlarının ve koruma amaçlı kullanılan hayvanların da haczedilemeyeceği hükmünü içermektedir. Almanya'da ise 1990 yılında yapılan düzenleme ile hayvanların icra prosedüründeki durumuna ilişkin iki önemli değişikliğe gidilmiştir. Bunlardan ilki, Alman Medeni Usul Kanunu'na (ZPO) eklenen §811c hükmüdür: Hükmün ilk fikrasına göre, ev ortamında yaşayan ve ekonomik amaçlara hizmet etmeyen hayvanlar ${ }^{101}$ haczedilemeyecektir. İkinci fikra uyarınca, hayvanın değerinin yüksek olması ve hacizden muaf tutulmasının alacaklı açısından haklı görülemeyecek bir güçlük yaratması halinde bu kurala istisna yapılması mümkündür; ancak bu halde de mahkemenin, borçlunun haklı menfaatleri ile hayvanların korunmasına ilişkin gerekleri dikkate alarak bir değerlendirme yapması gerektiği öngörülmüştür ${ }^{102}$. Her ne kadar mahkemenin yapacağı değerlendirmeye hayvanları korumaya ilişkin telakkiler de dahil edilmişse de, §811c'nin uygulama alanının ev hayvanları ile sınırlandırılmış olmas $1^{103}$, korunan menfaatin hayvanın içsel değeri değil, sahibinin onunla olan yakın ilişkisi olduğu göstermektedir ${ }^{104}$. Almanya'da başka bir değiş̧iklik ZPO §765a hükmünde yapılmıştır. Bu hüküm, icra mahkemesine, bir icra tedbirinin borçlu için ahlaka aykırılık teşkil edecek derecede güçlük yaratması halinde bu tedbiri borçlunun talebi üzerine kaldırma, değiştirme veya erteleme yetkisini vermektedir. Hükümde 1990'da yapılan değişiklik ile, bu tedbirin bir hayvana ilişkin olması halinde, mahkemenin, yapacağı değerlendirmede insanoğlunun hayvan karşısında taşıdığ1 sorumluluğu (Verantwortung des Menschen für das Tier) da dikkate alması gerektiği öngörülmüştür. Bu durumda, bir hayvana ilişkin olarak gerçekleştirilecek cebri icra tedbirlerinin, Alman Hayvanları Koruma Kanunu ile belirlenen standartlara uygun olmas $1^{105}$ ve olası tedbir kararının, alacaklının menfaatlerinin, sadece borçlunun değil, hayvanın da menfaatleri ve ihtiyaçları ile dengelenerek alınması gerekmektedir ${ }^{106}$. Bu

rarement saisis, d'abord pour des raisons charitables, ensuite parce qu'ils sont malaisés à revendre. Or, compte tenu de la situation économique actuellement difficile, tout porte à croire que le nombre des saisies est appelé à augmenter, et que la question de la saisie des animaux se posera donc de plus en plus souvent et sera même mise sur la place publique. Pour éviter les risques d'abus, la modification proposée concerne elle aussi uniquement les animaux vivant en milieu domestique et qui ne sont pas gardés dans un but patrimonial ou de gain." (Komisyon Raporu, s. 3894)

100 Steinauer, Tertium datur, s. 60.

101 Hükmün uygulama alanı hakkında bkz. Anja Forbriger, ZPO § 811c, BeckOK ZPO, ed. Vorwerk Volkert/Wolf Christian, C.H. Beck Münih, 2018, para. no. 2; Urs Gruber, Münchener Kommentar zur ZPO, Band 2, ed. Krüger Wolfgang/Rauscher Thomas, 5. Bası, 2016, para. no. 3.

102 Hayvanların korunması amacına aykırı olan ve hayvanın haczedilmesine engel olabilecek bir durumun, örneğin, annesine bağımlı genç bir hayvanın veya borçlu ile arasında duygusal bir bağ olan bir hayvanın söz konusu olduğu durumlarda karşımıza çıkabileceği yönünde, Forbriger, para. no. 7; Gruber, para. no. 7. Alman Hayvanları Koruma Kanunu'nun emredici hükümleri ile bağdaşmaz nitelikteki bir haczin her halükarda mümkün olmaması gerekir (Gruber, para. no. 7).

103 ZPO §811'de sayılan hayvanların haciz kapsamı dışında bırakılmaları ise borçlu veya ailesinin geçimleri için gerekli olmalarının sonucudur; Thomas Gergen, "Tiere in der deutschen Rechtsgeschichte und im geltenden Recht", Natur und Recht, C. 34, I. 2, 2012, s. 101.

104 Gergen, s. 101.

105 Lennkh, s. 316.

106 Lennkh, s. 316. 
alandaki diğer düzenlemelerden farklı olarak, salt ev hayvanlarını konu almayan, hayvanların haciz konusu olabildiği her durumda uygulanması gereken bu hükmün, §811c'den farklı olarak, hayvanı insan için koruma amacının ötesine gittiği, hayvanın kendi menfaatlerini de başlı başına hukuki bir değer olarak benimsediği söylenebilir.

\section{(iii) Hayvanları malikleri için koruyan diğer kurallar}

Hayvanların insanlar için korunması amacını güden normlara verebileceğimiz bir diğer örnek, yine 2002 yılında İsviçre Medeni Kanunu'nun 728. maddesinde yapılan değişikliktir. Yeni hükümde ev ortamında yaşayan ve kazanç amacı ya da maddi bir amaç güdülmeden tutulan hayvanlar açısından kazandırıcı zamanaşımı, diğer taşınır eşyalarda cari olan beş yıl yerine iki ay olarak belirlenmiştir. Düzenlemenin yine herhangi bir hayvana değil, sadece ev ortamında yaşayan hayvanlarına uygulanacak olmas1, korunan değerin insanların bu hayvanlarla kurduğu manevi bağ olduğunu göstermektedir.

Fransız temyiz mahkemesinin aynı düşünceye dayanan yakın tarihli bir kararı, hayvanların diğer eşyalardan farklılaştırılmasının olası etkisinin genişliğine de işaret etmesi açısından dikkat çekicidir. Temyiz mahkemesi, bu konuda hiçbir kanuni açıklık olmamasına rağmen, hayvanın sahibi için taşıdığı manevi değeri, satım sözleşmesinde ayıba karşı tekeffül hükümlerinin yorumlanmasında dikkate almıştır. Karara konu olan olayda, bir profesyonel hayvan yetiştiricisi tarafından ev hayvanı olarak satılan köpeğin görme bozukluğu olduğunun ortaya çıkması üzerine alıcı, tüketici hukukuna dayalı olarak ayıbın giderilmesini ve zararının tazminini talep etmiştir. Satıcı, bu seçeneklerin orantısız biçimde masraflı olduğu gerekçesiyle misliyle değiştirme seçeneğini önermiştir. Gerçekten de, Fransız Tüketici Kanunu'nun (Code de la consommation) L211-9. maddesi uyarınca, onarım ve misliyle değiştirme seçenekleri arasında alıcının talep ettiği giderim biçiminin orantısız biçimde masraflı olması halinde, satıcının diğer seçeneği hayata geçirme hakkı bulunmaktadır, meğer ki satıcı için daha masrafsız olan seçeneğin icrası imkansız olsun. Satım sözleşmesinin konusu olan hayvan da, bu sözleşme tahtında eşya olarak telakki edildiğine göre, bu hükmün uygulanması sonucu satıcının, onarımdan (tedaviden) daha az masraflı olan misli ile değiştirme seçeneğini kullanabilmesi gerekir. Ancak kararda temyiz mahkemesi, satılan köpeğin "yaşayan bir varlık, tek ve yerine başkası konulamaz" niteliğinde, "ekonomik bir amaca yönelmeksizin, sahibinin sevgisini almaya yönelmiş bir ev hayvanı" olduğunu belirterek, misli ile değiştirilmesinin imkansız olduğunu ve satıcının onarım seçeneğini uygulamak zorunda olduğu yönünde hüküm kurmuştur ${ }^{107}$.

Yukarıda açıklanan normlar, hayvanların hak nesnesi olarak konumlandırılmasını sorgulamamakta, ancak onları diğer eşyalardan farklı bir rejime tabi tutmaktadır.

$\overline{107}$ 1. Hukuk Dairesi, 9 Arallk 2015, Esas no 14-25910. 
Bununla beraber bu normlar çoğunlukla ev hayvanlarını esas almakta ve bundan farklı amaçlarla insanların kontrolü altında bulunan hayvanları kapsam dışı bırakmaktadır. $\mathrm{Bu}$ çerçevede hayvanın menfaatinin, ancak insanın bu belirli hayvanla manevi bir bağ kurmuş olması şartıyla ve bu ölçüde hukuken değer gördüğünü, yani korunan asıl menfaatin insanın menfaati olduğunu görmekteyiz ${ }^{108}$. Bu yönleriyle bu düzenlemeler hayvanları insan menfaati için koruyan antroposantrik yaklaşıma dayanmakta ${ }^{109}$ ancak hayvanları salt ekonomik değil, duygusal bağların da konusu olabilecek varlıklar olarak hukuk düzenine dahil etmektedirler. Bu durum, dolaylı biçimde de olsa hayvana özel bir konum sağlamakla beraber, hayvanın hak öznesi olmaya doğru evrildiğini iddia edebilmek için yeterli değildir. Hak öznesi olarak kabul edilmenin olmazsa olmaz koşulu, hayvanların insanların menfaatleri için değil, kendi içsel değerleri, kendi menfaatleri için korunmalarıdır.

\section{b. Hayvanların Kendileri İçin Korunmaları}

Hayvanları insanlar için değil, kendileri için koruyan normlar, hayvanın korunması yoluyla insanın korunmasını temel hedef olarak koymayan, hayvanların kendilerine has ve korunmaya mazhar menfaatleri olduğunu kabul eden ve bu menfaatleri koruyan normlardır. Bu tür bir amaca dayanan koruma normları, insanlarla hayvanlar arasında çıkan menfaat çatışmasının hayvanlar lehine çözülmesi düşüncesine dayanmakta ve insan davranışlarına hayvanlar lehine sınırlamalar getirmektedirler.

\section{(i) Hayvanların açıkça eşya kategorisinden çıkarılmaları}

Hayvanların eşya olarak telakki edilmemesine ilişkin olarak geliştirilen ilkesel adımlardan biri, bazı ülkelerin Medeni kanunlarının hayvanları eşya kategorisinden ç1karması olmuştur.

İsviçre'de 2002 yılında hayvanların hukuki konumunu iyileştirmek amacıyla yapılan revizyonun ilkesel anlamda getirdiği en önemli yenilik, hayvanların eşya statüsünden açıkça çıkarılması olmuştur ${ }^{110}$. İsviçre Medeni Kanunu'na eklenen 641a maddesinin birinci fikrası, "Hayvanlar eşya değildir" ifadesini içermektedir. Alman Medeni Kanunu’nun §90a hükmü de 1990’da yapılan revizyondan bu

\footnotetext{
$\overline{108}$ Bu yönde, Bolliger, Legal Protection s. 361; Lennkh, s. 314-315; Brehm, s. 118. Brehm, İsviçre'de yapılan düzenlemeleri hayvanların eşya statüsünden çıkarılmasının doğal sonucu olarak görmekte, ancak İBK düzenlemelerinin salt ev hayvanlarına yönelik olmasının, kanun koyucu için bazı hayvanların diğerlerinden « daha az eşya » olduğunu gösterdiğini ifade etmektedir. Yazara göre tam da bu durum, bu normların amacının hayvanların korunmasını değil, insanın hayvan için besleyebileceği duyguların değer kazanmasnı sağlamak olduğunu gösterir (Brehm, s. 118).

109 Bolliger, Legal Protection, s. 361.

110 İsviçre Federal Mahkemesi, 1989 yılında verdiği bir kararda bu değişikliğe olan ihtiyacı dile getirmiştir : "Zwar werden Tiere von der Rechtsordnung nach wie vor als Sachen behandelt. Die Grundeinstellung des Menschen zum Tier hat sich jedoch mit der Zeit im Sinne einer Mitverantwortung für diese Lebewesen zum sogenannten "ethischen Tierschutz" (...) entwickelt, welcher weiter geht als der Schutz lebloser Dinge, und welcher das Tier als lebendes und fühlendes Wesen, als Mitgeschöpf anerkennt, dessen Achtung und Wertschätzung für den durch seinen Geist überlegenen Menschen ein moralisches Postulat darstellt (...). Den heutigen ethischen Vorstellungen vermag nur ein umfassender Lebensschutz auch des tierischen Lebens gerecht zu werden, wobei gewisse Ausnahmen (...) den Grundsatz nicht zu erschüttern vermögen." (BGE 115 IV 248, 2 Ağustos 1989).
} 
yana "Hayvanlar eşya değildir" ifadesini içermektedir. Keza, Avusturya Medeni Kanunu'nun §285a hükmü, "Hayvanlar eşya değildir; özel kanunlarla korunurlar" cümlesi ile başlamaktadır. Fransız hukukuna baktığımızda bu kabulün uzun ve sancılı bir süreç sonucu ve daha dolaylı biçimde ortaya çıktığını görüyoruz. Bu alandaki ilk düzenleme, 10 Temmuz 1976 tarihli kanunun 9. maddesi olarak yürürlüğe girmiştir. Bugün Köy ve Deniz Balıçıllı̆̆ Kanunu'nun (Code rural et de la pêche maritime) L214-1 maddesi haline gelmiş olan bu düzenleme uyarınca "Duyarlı bir varlık olan her hayvan, maliki tarafindan türünün biyolojik gerekleri ile uyumlu şartlar içinde bulundurulmalıdır”. Böylece, eşya kategorisinin içinde, kendine has ihtiyaçları olan ve "duyarlı hayvan" olara betimlenen yeni bir alt kategori yaratılmıştır. 6 Ocak 1999 tarihinde yapılan Fransız Medeni Kanunu değişikliği ise, kanuna taşınır ve taşınmaz eşya yanında "hayvanlar" ibaresini eklemiştir. Bu değişiklik de hayvanları eşya olmaktan çıkarmamış, ancak, onların diğer eşyaların yanında, kendi kendilerine hareket edebilen varlıklar olarak kendi isimleri ile anılmalarını sağlamıştır ${ }^{111}$. Nihayet, 16 Şubat 2015 tarihinde Fransız Medeni Kanunu'nda yapılan değişiklik ile hayvanlar kendilerine ait bir statüye kavuşmuştur. Kanunun 515-14. maddesi "hayvanlar, duyarlılığa sahip canlı varlıklardır" cümlesini getirmiş ve hayvanların, cansız varlıklardan farklı bir hukuki statüye sahip olmasını ilkesel olarak kabul etmiştir ${ }^{112}$. Böylece, Fransız hukukunda da hayvanların ${ }^{113}$ en azından biçimsel olarak eşya kategorisinden çıkarılmış olduğu söylenebilir ${ }^{114}$.

Hayvanların eşya olmadığının kanun koyucu tarafından beyan edilmesi nasıl bir ilerleme sağlayacaktır? Hayvan eşya olmaktan çıkmış ise, kişi kategorisine mi girmiş olmaktadır? İlgili düzenlemeler, hayvanın eşya olmadığını söylemekle beraber, Fransız hukukundaki "duyarlı varlık" ibaresi dışında, ne olduğunu söylememektedirler ${ }^{115}$. Bunun da ötesinde, temel ilkeyi koyduktan hemen sonra, süregelen durumu çok da zedelemeyecek başka bir ilke getirmektedirler: Hayvanlar, kendilerine ilişkin özel hüküm bulunmayan hallerde, yine eşyalara ilişkin hükümlere tabi olacaklardır. Eşyalara ilişkin kuralların hayvanlar için de genel hükümler olarak kalmaya devam etmesi, ortada gerçek bir değişiklik olup olmadığı, konulan ilkenin normatif değerinin bulunup bulunmadığı konusunda şüpheler yaratmıştır ${ }^{116}$.

\footnotetext{
111 Caire, s. 9.

$112 \mathrm{Bu}$ ifadenin hayvan kavramını tanımlamadığı, kanuna, hayvanlar ve insanlar için ortak nitelikteki "canlı ve duyuları olan varlık" kategorisini dahil ettiği yönünde, Philippe Reigné, "Les animaux et le Code Civil”, La Semaine juridique-Edition générale, S. 9, 02.03.2015, s. 242. Yazara göre, bu ikisi farklı statülere (kişi ve eşya) tabi tutulmakla beraber artık ikisinin ortak özelliğini yansıtan yeni bir kategori yaratılmıștır.

113 Hükmün vahşi hayvanları da kapsadığı görüşünde, Louise Scalbert, "Utilité et force symbolique du droit- A propos de la reconnaissance dans le Code Civil de l'animal comme "etre vivant doué de sensibilité"', Revue de droit rural, S. 432, 2015, para. no. 3; aksi görüşte, ancak yapılan ayrımı eleştirerek, Reigné, s. 242 vd.

114 Reboul-Maupin, para. no. 12.

115 Michel/ Schneider Kayasseh, s. 20; Reboul-Maupin, para. no. 8.

116 Le Bot, Grandes evolutions, s. 255; Reboul-Maupin, para. no. 12. Bu nedenle Fransa'da bazı parlamenterler hayvanların canlı varlık olarak kanunda zikredilmiş olmasının sadece "sembolik" veya "kozmetik" nitelikte olduğunu dahi ifade etmişlerdir: Scalbert, para. no. 3. İsviçre'de de mecliste yapılan tartışmaların parlamenterlerin yeni bir kategori yaratma amacını gütmediklerini gösterdiği yönünde, bkz. Steinauer, Tertium datur, s. 55-57.
} 
Hükmün hukuki bir etki yarattığı görüşündeki yazarlardan bazıları, hayvanlar için eşya ve kişi yanında üçüncü bir kategori yaratılmış olduğunu ${ }^{117}$, bazıları ise hayvanların, insan dışı yaşayan varlık sıfatıyla, kendine özgü bir hak nesnesi olarak eşyalardan ayrılmış olduğunu ${ }^{118}$ savunmuştur. Bazı yazarlara göre ise bu hükümlerin hayvanların özel koruma normlarına tabi olduğunu hatırlatmanın ötesinde bir anlamı bulunmamaktadir ${ }^{119}$.

Hayvanların eşya olmadığının veya duyarlı varlık olduğunun hukuki metinlere geçirilmesi ile verilen mesaj, hayvanların keyfi biçimde kullanılamaz olduğu, bu varlıkların diğer eşyalardan farklı olarak, yaşayan ve hisseden varlıklar olmalarının, hukuk düzeni tarafından göz ardı edilemeyeceği yönündedir ${ }^{120}$. Kanun koyucular, bir yandan hayvanların ayni hak konusu olmaya devam etmeleri gereği ile onları hissetme ve belirli ölçüde düşünme yetileri itibarıyla diğer nesnelerden farklı tutma isteğini uzlaştıracak bir çözüm bulmaya, hayvanları sadece nesne olarak gören medeni hukuk geleneğinden kısmi bir ayrılış sağlamaya çalışmışlardır ${ }^{121}$. Bu çabanın sonucu olarak hayvanların eşya hukuku kurallarına tabi tutulması, önceki durumdan farklı olarak, ikincil nitelikte bir rejim haline gelmiştir: Hayvanlar, ancak kendilerini koruyan başka hükümler bulunmaması halinde eşya hukuku kurallarına tabi olacaklardır ${ }^{122}$. Bu durumda, ilgili hükümlerin hayvanları hak nesnesi olmaktan çıkarmamakla birlikte, en azından şekli olarak diğer eşyalardan farklı bir konuma koyduklarının kabulü gerekir. Bu şekli durumun somut bir içerik kazanıp kazanmayacağı, hayvanlara uygulanacak, tutarlı bir bütün oluşturan hukuk kurallarının gelişimi ile açıklığa kavuşacaktır. Başka bir deyişle, ilgili hükümlerin hukuki değere kavuşturulması için hayvanların gerçek bir özel statüye sahip olmasını sağlayacak, onları koruyucu normların çoğaltılması gereklidir ${ }^{123}$. Bu açıdan, yapılan

117 İsviçre açısından bkz. Stucki, Die «tierliche Person», s. 288-289; Stucki, Rechtstheoretische Reflexionen, s. 146; Uyumaz, s, 145; Almanya açısından, hayvanların hukuk öznesi yapılmak istenmediği ancak aynı zamanda sadece bir yollama yoluyla hak nesnesi ile aynı duruma getirilmiş olduğu, hayvanlara tanınan bu özel statü ile hak sahibi ile hak nesnesi karşıtlığına dokunulmamış olduğu yönünde, bkz. Stresemann, para. no. 3.

118 İsviçre açısından, bkz. Wiegand, s. 894-895; Stephan Wolf, Art. 641a, ZGB Kommentar- Schweizerisches Zivilgesetzbuch, ed. Kren Kostkiewicz Jolanta/ Wolf Stephan/ Amstutz Marc/ Fankhauser Roland, 3. Bası, Orell Füssli, 2016, s. 1222; Steinauer, Tertium datur, s. 57; Paul-Henri Steinauer, Les droits réels, Tome I, 5. Bası, Stämpfli editions SA, Bern, 2012, s. 66 .

119 İsviçre açısından, bkz. Jörg Schmid/Bettina Hürlimann-Kaup, Sachenrecht, 4. Bası., Schultess, 2012, s. 2; Ruth Arnet, Art. 641a, Sachenrecht 641-977 ZGB, Handkommentar zum Schweizer Privatrecht, ed. Breitschmid Peter/ Jungo Alexandra, 3. Bası, Schulthess, Zürih, 2016, s. 16; Rey, s. 40-42; yapılan bu düzenlemelerin, eşya kavramının bütün unsurlarını taşıyan hayvanları eşya olmaktan çıkarmaya yetmediği, bu durumun hayvanın mülkiyet konusu olmasının zorunlu sonucu olduğu, yapılan değişikliklerin toplumu daha duyarlı hale getirme amacını taşıdığı yönünde, bkz. Veysel Bașpınar, "Eşya Hukuku Bakımından Hayvanların Hukukî Durumu", 1926'dan Günümüze Türk İsviçre Medeni Hukuku, Medeni Kanun’un ve Borçlar Kanunu'nun 90. Y1lı Uluslararası Sempozyumu, Yetkin Yayınları, İstanbul 2016, s. 1383 vd. Almanya açısından bkz. Jürgen F. Baur/ Rolf Stürner, Sachenrecht, 18. Bası, C.H. Beck, Münih 2009, s. 12; § 90a'nın gerçek bir hukuki içeriği olmayan, duygusal bir açıklama ("gefühlige Deklamation") olduğu yönünde, Jürgen Ellenberger, Palandt-Bürgerliches Gesetzbuch, 71. Bası, C.H. Beck, Münih 2012, s. 68.

120 Michel/ Schneider Kayasseh, s. 20.

121 Reigné, s. 242 vd.; Scalbert, para. no. 3.

122 Hayvanların artık hukuken "eşya olarak" değil, "eşya gibi" muamele göreceği yönünde, bkz. Wiegand, s. 895; Stucki, Rechtstheoretische Reflexionen, s. 146.

${ }^{123}$ Reigné, s. $242 \mathrm{vd}$. 
değişikliğin hayvanları koruma kanunlarında değil de, Medeni Kanun'da kendine yer bulmuş olması, devamlılık arzusuna işaret etmekte, daha kapsamlı bir gelişimin ilk yap1 taş1 olarak düşünüldüğünü göstermektedir ${ }^{124}$. Öte yandan, eşya hukukuna ilişkin kuralların ikincil nitelikte olduğunun belirtilmesi, bu kuralların hayvanın canlı varlık olma niteliğine uygun düşmediği hallerde uygulanmaması için yarg1 organlarına da olanak sağlamaktadır ${ }^{125}$. Bu itibarla, kanun koyucuların özel koruma normları geliştirmekte gösterdiği ataletin yargısal faaliyetle de kırılması mümkün olabilir. Başka bir deyişle, hayvanın bu yeni niteliği çerçevesinde bir içtihat hukukunun şekillenmesini beklemek de meşru hale gelmiş olmaktadır ${ }^{126}$.

\section{(ii) Hayvanlara yaşama hakkı tanınması}

Hayvan haklarının iyileştirilmesi için, ülkemiz de dahil olmak üzere pek çok ülkede yürülüğe konulan hayvanları koruma kanunlarının ortak noktası, hayvan refahını sağlamayı açık bir amaç olarak ifade etmeleridir. Bu amaç çerçevesinde ilgili düzenlemeler, hayvanların acı çekmelerini ve türlerinin gereklerine uygun olmayan şartlarda tutulmalarını asgari düzeye indirmeye çalışmaktadırlar. Ancak, acı çekmeme amacından daha da temel nitelikte görülebilecek olan yaşama hakkı konusunda kanun koyucular daha çekimser davranmıştır. Örneğin, İsviçre'de Hayvanları Koruma Kanunu, ilk maddesinde hayvanın onurunu ve refahını korumayı amaç olarak belirlemekte, ancak hayvanlar için genel bir yaşama hakkı tanımamaktadır ${ }^{127}$. Bu hakkın temin edilmemesi, hayvanın, gereksiz yere acı çekmesine sebep olunmadı̆̆1, böylece refahını ve onurunu koruma altına alan normlara aykırı davranılmadığ sürece ${ }^{128}$, sahibi tarafından herhangi bir gerekçe de gösterilmeksizin öldürülebilmesi sonucunu doğurmaktadır ${ }^{129}$. Yaşama hakkını açıkça tanıyan bir düzenlemeyi ise Alman Hayvanları Koruma Kanunu'nda görmekteyiz. Kanunun birinci paragrafi, kanunun amacını hayvanların yaşamını ve refahını korumak olarak tanımlamış ve hiç kimsenin, makul bir sebep olmadığı sürece, bir hayvana acı veya zarar veremeyeceğini hükme bağlamıştır. Böylece kanun, sadece yaşamakta olan hayvanın refahını değil,

\footnotetext{
${ }^{124}$ Ibid.; Scalbert, para. no. 16. İnsan ile hayvan arasındaki mesafenin biraz olsun kısalmasının hayvanların kullanımını konu alan faaliyetlerin hukuki çerçevesinde anlamlı değișiklikler getirebileceği, hayvan üretimi ve ticareti konularına eskisinden farklı yaklaşılmasını sağlayabileceği yönünde, bkz. Manuel Carius, "A la recherche de l'animal juridique”, Revue de droit rural, 2015, no 432.

125 BGB §90a ile getirilen özel statünün, kanun koyucunun etik anlayışa dayalı hayvan koruması lehine bir değerler seçimi yaptığı ve bu anlamda hukukun uygulanması ve yorumlanması aşamasında da dikkate alınması gereken yasal bir uyarı olduğu yönünde, bkz. Stresemann, para. no. 3, 8 .

126 Doğal varlıklar açısından bu yönde, Stone, s. 488-489. Yazara göre, "nehirlerin hakları vardır” cümlesine sahip bir hukuki sistem, özünde aynı kuralları içeren, ancak bu cümleye sahip olmayan bir hukuki sistemden daha farklı biçimde evrilebilir (s. 489).

127 Stucki, Rechtstheoretische Reflexionen, s. 146; Bolliger, Legal Protection, s. 357; Michel/ Schneider Kayasseh, s. 15; Stucki, Die «tierliche Person», s. 295, dn. 44; Michel, s. 612.

128 İsviçre Hayvanları Koruma Kanunu, hayvanların acı çekmeden öldürülmelerini sağlamak için hükümler içermektedir Bunlardan en tartıșmalı olanı, kanunun 21. maddesinde yer verilen, memeli hayvanların anestezi yapılmadan öldürülmeleri yasağıdır. Konu, kurban ibadetinin gerekleri ve bu çerçevede din özgürlüğ̈ ile yaşanan çatışma nedeniyle tartışılmaktadır; bkz. Michel/ Schneider Kayasseh, s.15, dn. 95.

129 Bolliger, Legal Protection, s. 358
} 
hayvanın yaşama hakkını da koruma altına almışs ${ }^{130}$ ve aksi yöndeki insan davranışının hukuka uygunluğu için makul sebebe dayanma şartını getirmiştir ${ }^{131}$.

\section{(iii) Hayvan onurunun korunması}

Hayvan onuru (animal dignity) kavramının hukuki metinlere yansıtılması, İsviçre hukukunda hayvan hakları hukuku alanında atılan en önemli adımlar biri olmuştur. Hayvanların fiziksel ve psikolojik stresten korunması fikrinin de ötesine geçen bir şekilde, hayvanın kendi içsel değerinin, kendisi için korunması fikrine dayanan bu kavram $^{132}$, 1992 yılında yapılan bir anayasa değişikliği sonucu Federal Anayasa'nın (Constitution fédérale de la Confédération suisse) 120/2. maddesinde "canlı varlığın onuru" adı ile yerini almıştır. Bu hüküm uyarınca, konfederasyon, hayvanların, bitkilerin ve diğer organizmaların germinal ve genetik miraslarının kullanımını, canlı organizmaların “onuruna” (Würde/dignité) ${ }^{133}$, insanoğlunun, hayvanın ve çevrenin güvenliğine sayg1 göstererek ve hayvan ve bitki türlerinin genetik çeşitliliğini koruyarak düzenleyecektir. ${ }^{134}$. Böylece "canlı varlığın onuru” kavramı İsviçre hukukunda anayasal düzeyde bir değer olarak benimsenmiş olmaktadır. Canlı varlık kavramının kapsamına, insan dışında tüm canlı varlıkların, özellikle de hayvanların girdiği $i^{135}$, böylece tüm hayvanlara, salt canlı varlık olma nitelikleri nedeniyle, idrak ve hissetme yetilerine bakılmaksızın koruma sağlanmış olduğu kabul edilmektedir ${ }^{136}$. Keza, her ne kadar hüküm genetik teknoloji alanında yapılabilecek suistimallere karşı canlı varlığ 1 koruma amacıyla ihdas edilmiş olsa da ${ }^{137}$, sağladığ 1 korumanın sadece bu alanla sınırlı olmadığının, insan ile hayvan arasındaki ilişkilerin her aşamasında geçerli bir temel ilke barındırdığının hem öğretide ${ }^{138}$ hem de İsviçre Federal Mahkemesi kararlarında ${ }^{139}$ altı çizilmiştir. Ancak, bir yazarın da işaret ettiği gibi, "anlamlı kelimeler çoğunlukla

130 Michel, s. 616.

131 Makul sebebin ne şekilde değerlendirileceği konusunda, bkz. Michel, s. 617; makul sebep kavramının çatışan haklar ve ödevler arasında, faydanın zarardan üstün tutulmasına dayalı bir seçimi gerektirdiği yönünde, Lennkh, s. 312. Avusturya Hayvanları Koruma Kanunu da aynı şekilde, hayvanların yaşamının ve refahının korunmasını kanunun amacı olarak belirlemiş ve makul gerekçe olmadan hayvanların öldürülmesinin yasak olduğunu hükme bağlamıştır (para. no. 1 ve no. 6).

132 Bolliger, Legal Protection, s. 313.

133 Metnin Almanca versiyonunda "Würde" ifadesi geçerken, ilk Fransızca versiyonunda buna tekabül eden "dignité" ifadesi, sonradan, 1999 yılında yapılan Anayasa revizyonu sırasında "integrité" haline gelmiştir. "Bütünlük" anlamına gelen bu yeni ifade, orjinal versiyondaki ve metnin diğer dillerde halen kullanılmakta olan "onur" kavramını karşılamamaktadır. Bu değişikliğin hukuki etki doğurmadığı, nitekim çevirmenlerce yapılmış olduğu yönünde, Bolliger, Legal Protection, s. 325; Michel/ Schneider Kayasseh, s. 4; Le Bot, Protection de l'animal, s. 17-18.

134 Hükmün ihdas edilmesi süreci için, bkz. Evans, s. 239 vd.

135 Michel/ Schneider Kayasseh, s. 4.

136 Bolliger, Legal Protection, s. 327.

137 Hayvan onuru kavramının, özellikle bu maddede öngörüldüğü gibi biyoteknoloji alanında benimsenmiş olmasının, hayvanlara ve türlere genetik müdahalelere ilişkin etik kaygıları en iyi şekilde yakalayan kavram olduğu yönünde, Loder, s. 62.

138 Michel/ Schneider Kayasseh, s. 3; Bolliger, Animal Dignity, s. 37.

139 "Die Beachtung der Würde der Kreatur wird zwar nur in der Kompetenzvorschrift der Gentechnologie im Ausserhumanbereich ausdrücklich erwähnt, dort aber als etwas Existierendes vorausgesetzt. Nur etwas Existierendem kann Rechnung getragen werden. Kreaturen kommt deshalb unabhängig von der Gentechnologie im Ausserhumanbereich Würde zu." (BGE 135 II 384, 7 Ekim 2009). 
tanımlanmaları en zor olanlardır’"140. Hayvan onuru kavramının özgünlüğü ve insanların hayvanlarla olan ilişkisinde yeni bir paradigmaya işaret ediyor olması, bu kavramın içeriğine ilişkin tartı̧̧maları, özellikle insan onurunun korunması ile paralellik kurulup kurulamayacağ 1 sorusu çerçevesinde gündeme getirmiştir ${ }^{141}$.

Hayvan onurundan ne anlaşılması gerektiği konusundaki tartı̧̧alar üzerine konu, 1 Eylül 2008'de yürürlüğe giren İsviçre Hayvanları Koruma Kanunu'nda daha ayrıntılı bir düzenlemeye kavuşmuştur. Kanunun birinci maddesi, kanunun amacını « hayvanın onurunu ve refahını korumak » olarak tanımlamışıır ${ }^{142}$. Kanunun tanımlar başlıklı üçüncü maddesinde ise, hayvan onuru, hayvanın refahından farklı bir kavram olarak, «hayvanın, onunla iştigal eden kişiler tarafindan saygı gösterilmesi zorunlu olan, içsel değeri » olarak tanımlanmıştır. Kanun, hayvana acı veya zarar verilmesini, onu kaygıya sürükleyen veya küçük düşüren, türüne ait niteliklerini veya yetilerini önemli ölçüde değiştiren müdahalelere maruz bırakılmasını veya aşırı biçimde enstrümentalize edilmesini hayvan üzerindeki baskının örnekleri arasında saymış ve bu tür bir baskının, bunu haklı gösteren daha üstün bir menfaat bulunduğu ortaya konulamadığı sürece hayvan onurunu ihlal teşkil edeceği hükme bağlanmıştır. Burada sözü edilen küçük düşme veya enstrümentalize edilme halleri, hayvanın refahının korunması, yani fiziksel ve psikolojik açıdan türüne uygun şartlarda yaşaması için gerekli ortamın oluşturulması amacının ötesine geçen bir koruma amacını yansıtmaktadır. Nitekim hayvanın böyle bir duruma maruz bırakılması, hayvanın kendisi bunu bir olumsuzluk olarak tecrübe etmese dahi hayvan onuruna aykırılık teşkil edecektir ${ }^{143}$.

Onur kavramının bu şekilde yasal metinlere girmesi, geleneksel olarak insanlara atfedilen bir niteliğin diğer canlı varlıklara da teşmil edilmesi anlamına gelmekte ${ }^{144}$ ve böylece insan varlığına hasredilen bir koruma alanından, diğer canlı varlıkların da istifade etmesi arzusunu yansitmaktadır. Ancak, hayvan onuru kavramına verilen anlam, hayvanlara insanların sahip olduğu korumaya paralel bir koruma sağlamaktan uzaktır. Öncelikle, anayasanın onur kavramını tüm hayvanlar, hatta tüm canlı varlıklar için öngörmesine rağmen, bu kavramı hayata geçirecek olan kanunun kural olarak sadece omurgalı hayvanları esas almas $1^{145}$ ve böylece, koruma amacını acı çekme yetisine indirgemiş olması içsel bir çelişki olarak karşımıza çıkmaktadır ${ }^{146}$.

\footnotetext{
${ }_{140}$ Loder, s. 2.

141 Hayvan onuru kavramının insan onuru kavramı ile ilişkisi hakkındaki tartışmalar için, bkz. Michel/ Schneider Kayasseh, s. 5-11.

142 Hayvan refahı kavramı, daha önce yürürlükte olan 1978 tarihli kanunda da yer almasına rağmen, hayvan onuru kavramı kanunun 2008'de yürürlüğe giren versiyonuna özgüdür.

143 Bolliger, Legal Protection, s. 338. Hayvan onuru kavramı üzerine ayrıntılı bir inceleme için, bkz. Loder, s. 1 vd. Yazar, hayvanların türsel niteliklerine ve insanlarla olan ilişkilerine göre farklı onur himayesi ihtiyacı altında bulunduklarının altını çizmiş ve bu iliş̧kisel kategorilere göre (ev hayvanı, deney hayvanı, vs.) hangi değerlerin hayvan onuru çerçevesinde değerlendirilebileceğini incelemiştir (Loder, s. 37 vd.)

144 Bolliger, Legal Protection, s. 324.

145 Bkz. yuk. II.

146 Bolliger, Legal Protection, s. 370.
} 
Yine, hayvanın onuru korunurken, hayvanın yaşama hakkından hiç bahsedilmemiş olması da korumanın kapsamını daraltmaktadır. Nihayet, kanunda hayvanın maruz bırakıldığı olumsuz durumların, hayvanın onurunu korumaktan üstün görülebilecek makul bir çıkarın bulunması halinde hukuka uygun hale geleceğinin öngörülmüş olması, hayvan onuru kavramının, insan onurundan farklı olarak, ihlal edilemez bir çekirdeğe sahip olmadığını, tamamen göreli bir değer olduğunu göstermektedir ${ }^{147}$. Sonuç olarak hayvan onurunun korunması, hayvanların insanlar tarafindan kullanılmasını sorgulamayan, ancak bu kullanım yetkisine yeni sınırlar çizilmesini öngören bir yöntem olarak karşımıza çıkmaktadır ${ }^{148}$. Çatışan menfaatler arasındaki dengenin nasıl kurulacağının kanun koyucu tarafından belirtilmemesi ise olay bazında yapılması gereken bir değerlendirmeyi zorunlu k1lmaktadır ${ }^{149}$.

Hayvan onuruna sadece göreli bir değer atfetse de yapılan düzenleme yine de ilerleme teşkil etmektedir. Birincisi, daha önce de belirttiğimiz gibi, hayvan onuru kavramı hayvan refahından daha geniş bir koruma alanı çizmekte ve daha fazla türde insani müdahaleyi sorgulanabilir kılmaktadır. Bu çerçevede, örneğin, hayvanlara kendi türlerine uygun olmayan, onları gülünç gösteren kostümler giydirilmesi hayvan onuruna aykırı görülerek engellenebilecek ${ }^{150}$; hayvanların temel ihtiyaçları ötesindeki ihtiyaçlarının da kanunun koruması altına alınması sağlanabilecektir ${ }^{151}$. İkincisi, bir müdahalenin hayvan onurunu zedelediği hallerde, faaliyetin kanuna uygunluğu ancak failinin üstün bir menfaatin varlığını ortaya koyması halinde kabul edilebilecektir ${ }^{152}$. Böylece hayvan onuru kavramı, kendisine yapılacak müdahaleleri gerekçelendirme yönünde yükümlülük doğurucu bir işlev üstlenmiştir ${ }^{153}$. Bu açıdan her türlü insan menfaatinin değil, ancak toplumda özel olarak üstün değere sahip olduğu kabul edilen, yiyecek üretimi, bilimsel araştırma, hastalıkların kontrolü gibi menfaatlerin kabul görmesi gerektiği ifade edilmektedir ${ }^{154}$. Bu gerekçelendirme zorunluluğunun uygulamaya geçirilmesinde bazı yazarlar, idare hukukunda uygulanan orantıl11ık testinin uygulanabileceğini ileri sürmüştür ${ }^{155}$. İsviçre hukukunda orantıl11ık testi, belirli bir fiilin, makul bir hedefe ulaşmak için gerekli olduğunun saptanması şartını da içermekte ${ }^{156}$, böylece, müdahalede bulunanın, hem hedefin makul olduğunu, hem

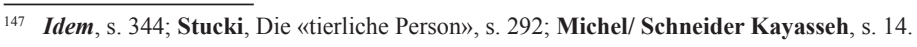

148 Michel/ Schneider Kayasseh, s. 17.

149 Bolliger, Legal Protection, s. 338; Michel/ Schneider Kayasseh, s. 14.

150 Michel/ Schneider Kayasseh, s.14.

151 İsviçre Hayvanları Koruma Kanunu'nun bu çerçevede yorumlanması gereken hükümlerine örnekler için, bkz. Bolliger, Legal Protection, s. 363.

152 Michel/ Schneider Kayasseh, s. 13.

153 Stucki, Die «tierliche Person», s. 292.

154 Bolliger, Legal Protection, s. 350. Hayvan onuruna yapılan müdahale ne kadar önemli ise, failden beklenen açıklamanın makul görülmesi için aranan şartlar o kadar ağırlaşmalıdır. Dolayısıyla, lüks ihtiyaçları, zevkleri ve hobileri tatmine yönelik muamelenin makul sebep olarak değerlendirilmemesi gerekir. Bazı durumlar için ise kanun koyucu soyut bir menfaatler tartımı yapmış ve -zoofili gibi- bazı eylemleri kategorik olarak yasaklamıştır (Bolliger, Legal Protection, s. 350-352).

155 Bolliger, Legal Protection, s. 346.

156 Ibid.
} 
de bu hedefe ulaşmak için hayvanları kullanmak dışında alternatif bir yöntemin var olmadığını ortaya koyması gerekmekte, aksi halde hayvanların kullanılması hukuka aykırı hale gelmektedir. Bu tür bir uygulama, örneğin, hayvanların salt kozmetik sektörün gelişmesi amacıyla ağır strese tabi tutulmasına sebep olan deneylerin hukuka uygunluğunu sorgulanabilir hale getirebilir. Son olarak, hayvan onurunun anayasal bir ilke olarak kendine yer bulmuş olması, bu ilkenin insanlara tanınan diğer temel haklarla aynı hiyerarşik seviyede olduğunu ve insan menfaatlerine genel bir üstünlük tanımanın bu normatif altyapıya da uygun olmayacağını göstermektedir ${ }^{157}$.

\section{(iv) Hayvanların malvarlığı değerlerinden yararlanmaları}

Hayvanların mülkiyet hakkına veya belirli malvarlığı unsurlarını kullanım hakkına sahip olup olamayacakları düşünüldügünde akla gelen ilk mesele, hayvanların, insanların müdahalesinden ari olarak yaşayabilecekleri alanlara sahip olmalarının sağlanıp sağlanamayacağıdır ${ }^{158}$. Gerek devletler gerekse özel kişiler tarafından hayvanlara yaşama alanları yaratılması özellikle türlerin korunması amacı çerçevesinde hayata geçirilebilen ve geliştirilmesi mümkün olan bir çözümdür ${ }^{159}$. Ancak bu konuda asıl tartışılan husus, bu kolektif imkanlardan ziyade, hayvan bireylerin, sadece kendilerinin kullanabileceği bazı malvarlığı değerlerine sahip olup olamayacağı meselesidir. Bu alanda özellikle bir hayvanın kendi faaliyeti ile ekonomik bir değer yaratması halinde bu değerden kendisinin de yararlanmasının nasıl sağlanabileceği ve hayvanın bir terekenin yararlanıcısı olup olamayacağ sorularına değinilmesi gerekir.

Bir hayvanın ekonomik bir değer yaratması halinde doğabilecek hukuki sonuçlar meselesi, 2011 yılında Endonezya'da yaşanan bir olay nedeniyle tüm dünyanın gündemine oturmuştur. Bir rezerv alanında hayvanları fotoğraflayan bir fotoğraf sanatçısı, makinesini kurulu olarak bırakmış, bu sırada makineye yaklaşan Naruto isimli makak maymunu, deklanşöre basarak kendi resimlerini çekmiş, fotoğrafçı bu görüntüleri kitabında kullanmıştır. PETA (People for the Ethical Treatment of Animals) organizasyonu 2015 yılında, Kaliforniya'da Naruto'yu temsilen açtığ davada, fotoğrafların Naruto tarafından, iradi bir fiille yaratıldığını, dolayısıyla eser üzerindeki hak sahibinin Naruto olduğunu iddia etmiştir. Yerel mahkemenin davayı reddetmesi üzerine ${ }^{160}$ PETA kararı temyiz etmiş, üst derece mahkemesi, olaya uygulanan fikri mülkiyet kanununun (Copyright Act), fikri mülkiyet ihlallerine

\footnotetext{
157 Bkz. yuk. II.

158 Bazı yazarlar, hayvanların kendilerine ayrılmıș yașam alanlarına sahip olmalarını, bir tür mülkiyet hakkı olarak nitelendirmektedirler; bkz. Bradshaw, s. 824. Hayvanlara bu anlamda mülkiyet hakkı tanınması ile ilgili olarak bkz. Bradshaw, s. 823 vd.; John Hadley, "Nonhuman animal property: Reconciling environmentalism and animal rights", Journal of Social Philosophy, C. 36/3, 2005, s. 305 vd.

159 Bu konuda, bkz. Bradshaw, s. 837-840.

160 Naruto v. David J. Slater, 28 Ocak 2016, Case no 15-cv-04324-WHO; karar metni için, bkz. https://law.justia.com/cases/ federal/district-courts/california/candce/3:2015cv04324/291324/45/, E.T. 21.11.2018
} 
ilişkin olarak hayvanlara açıkça dava ehliyeti tanımadığı gerekçesine dayanarak, bu yönde bir davanın açılabilmesinin ancak yasama organının hayvanları bu yönde açıç̧a yetkilendirmesi halinde mümkün olacağını belirtmiştir ${ }^{161}$. Her ne kadar dava Naruto'nun aleyhine sonuçlanmış olsa da, dava süreci konunun gelişime açık olduğunu düşündüren göstergeler de barındırmaktadır. Öncelikle kararda bir hayvanın, yürürlükteki hukuk çerçevesinde hak sahibi kapsamına giremeyeceği, ancak böyle bir hakkın kanun koyucu tarafından açıkça öngörülebileceği kabul edilmiştir. Öte yandan, her ne kadar davanın üst derece mahkemesinde karara bağlanmasına engel olmamış olsa da bu süreçte PETA ile davalı fotoğrafçının vardığı sulh anlaşması, hayvanların malvarlığı haklarına kavuşturulmasının somut ve pratik yöntemlerinden birini göstermiş olmaktadır. Bu anlaşma ile davalı fotoğrafçı, fotoğrafın kullanımı veya satımından elde edeceği gelirin \%25'ini Naruto'nun yaşadığı alanın ve Endonezya'daki aynı türden makakların korunmasını sağlayan hayır kurumlarına bağışlamayı kabul etmiştir ${ }^{162}$. Bu durum da göstermektedir ki, hayvanların maddi haklara sahip kılınması ile amaçlanan, kişilerinkine benzer bir malvarlığı yapısına kavuşturulmaları değil, belirli hayvan bireylerin veya hayvan topluluklarının belirli standartlar içinde yaşamalarını sağlayacak maddi olanakların bu amaçlara kanalize edilmesini sağlayacak hukuki mekanizmaların yaratılmasıdır. Bir hayvanın, maddi fiiliyle bir ekonomik değer yaratması haliyle sınırlı olarak açıkça hak sahibi olarak tanınması, bu değerin onun ihtiyaçlarına kanalize edilmesini kolaylaştırıcı etki yaratacaktır. Hayvanların çeşitli biçimlerde çalıştırılmakta olduğu gerçeği karşısında oluşan değerin onlarla paylaşılmasını zorunlu kılan mekanizmalar kurulması somut bir ihtiyaç olarak karşımıza çıkmaktadır.

Bir maddi değerin hayvanlarla paylaşılmasını sağlayan bir mekanizma ile miras hukuku alanında karşılaşmaktayız. Hayvanların kişi olarak kabul edilmiyor olmaları, mirasbırakanın ölüme bağlı tasarruflarla belirli bir hayvanı mirasçı olarak tayin edebilmesine engel oluşturmaktadır ${ }^{163}$; hatta hayvan, mülkiyet hakkının konusu olarak mirasbırakanın terekesinde yer alan ve üzerindeki mülkiyet hakkı mirasçılara geçen bir nesne olarak görülmektedir ${ }^{164}$.Ancak, ölüme bağlı tasarrufların koşula veya yüklemelere bağlı tutulabilmesini kabul eden sistemlerde, bir malvarlığının bir hayvanın bakımına özgülenebilmesi bu çerçevede mirasbırakan tarafindan sağlanabilir. İsviçre, Alman ve Avusturya miras hukuku kuralları, belirli hayvanların bakımının sağlanmasının

\footnotetext{
161 Naruto v. David J. Slater, Court of Appeal, 9th Circuit, 23 Nisan 2018, no. 16-15469; https://law.justia.com/cases/federal/ appellate-courts/ca9/16-15469/16-15469-2018-04-23.html, bkz. s. 15-18, E.T. 21.11.2018

162 https://www.peta.org/blog/settlement-reached-monkey-selfie-case-broke-new-ground-animal-rights/, E.T. 21.11.2018

163 İsviçre hukuku için, bkz. Anouchka Hubert-Froidevaux, Art. 482, Commentaire du droit des successions (art. 457-640 cc; art. 11-24 LDFR), Commentaire Stämpfli, ed. Eigenmann, Antoine/Rouillier, Nicolas, Stämpfli Verlag AG, 2012, s. 117; Philipp Studhalter, Art. 482, ZGB Kommentar-Schweizerisches Zivilgesetzbuch, ed. Kren Kostkiewicz Jolanta/ Wolf Stephan/ Amstutz Marc/ Fankhauser Roland, 3. Bası, Orell Füssli, 2016, s. 966, Michel/Schneider Kayasseh, s. 37; Ombline De Poret, "L'animal en droit des successions", Successio - Revue de droit des successions, 2008, s. 122; Alman hukuku için bkz. Gergen, s. 101.

164 İsviçre hukuku için, bkz. Michel/ Schneider Kayasseh, s. 37; De Poret, s. 132; Alman ve Avusturya hukukları için, bkz. Lennkh, s. 316, Alman hukuku için bkz. Gergen, s. 101.
} 
bu çerçevede mirasbırakan tarafindan sağlanabilmesini mümkün kılmaktadır ${ }^{165}$. İsviçre hukukunda 2002 yılında yapılan düzenleme, ölüme bağlı tasarrufta doğrudan doğruya mirasçı olarak bir hayvanın tayin edilmesi halinde durumun ne olacağına ilişkin bir açıklık da getirmiştir. İMK'nın 482. maddesinin 1 Nisan 2003 'te yürülüğe giren dördüncü fikrasına göre, bir hayvan lehine ölüme bağl1 tasarrufta bulunulması, hayvanın uygun bir şekilde bakımının sağlanması yönünde yükümlülük yaratılması anlamına gelmektedir. Hüküm hayvana mirasçı sıfatı kazandırmamaktadır ${ }^{166}$; ancak bir hayvanı mirasçı olarak tayin eden ve bu şekilde hüküm doğurması mümkün olmayan tasarrufun, yasal tahvil yoluyla, ilgili hayvanın, hukuk düzeninin hayvanların korunmasına ilişkin normları çerçevesinde bakımı ve korunması konusunda geçerli bir yükleme olarak hüküm doğurması mümkün olacaktır ${ }^{167}$. Belirtelim ki İBK'da yapılan değişikliklerden farklı olarak (m. 42 ve m. 43), bu maddenin salt ev hayvanlarına uygulanacağına yönelik bir sınırlama bulunmamaktadır. Böylece hayvanın hangi amaca özgülendiğine bakılmaksızın, yüklemenin yerine getirilmesi mümkün oldukça hüküm uygulanabilecektir ${ }^{168}$. Burada da hayvanın malvarlığı sahibi olması, belirli maddi kaynakların onun refahının sağlanması için kanalize edilmesi ve bu yönde bir dava hakkının oluşturulması anlamına gelmektedir. Bu noktada hayvanın yüklemeden fiilen nasıl yarar sağlayabileceği sorusu akla gelir. 482. maddenin birinci fikrasına göre, tasarruf hüküm ve sonuçlarını doğurduğu andan itibaren, her ilgili yüklemenin yerine getirilmesini isteyebilir ${ }^{169}$. İlgili kavramının kapsamına yüklemenin yerine getirilmesinde maddi veya manevi menfaati bulunan herkes girmektedir. Böylece, gerek doğrudan yükleme yaratılması, gerekse dördüncü fikra uyarınca tasarrufun yükleme yaratır şekilde yorumlanması halinde, hayvan hakları alanında çalışan derneklerin dava açmaları mümkün olabilecektir ${ }^{170}$. Aynı amaçla mirasbırakan da vasiyeti yerine getirme görevlisi atayabilirr ${ }^{171}$.

Belirtelim ki hayvanların bazı malvarlığı değerlerinden yararlanmasının sağlanması için başka mekanizmaların da kullanılması mümkündür. İsviçre hukukunda bu yönde bir sonuca vakıf kurulması yoluyla da ulaşılması mümkün görülmektedir ${ }^{172}$. Amerikan hukukunda da "faydalanan" sıfatıyla hayvanların tayin edilebileceği şekilde "trust" kurabilme imkanı açıkça düzenlenmiş bulunmaktadır ${ }^{173}$.

\footnotetext{
165 Lennkh, s. 316; De Poret, s. 118 vd.; Gergen, s. 101.

166 De Poret, s. 122.

167 Michel/ Schneider Kayasseh, s. 39; Studhalter, s. 966; De Poret, s. 123; hükmün "favor testamenti" ilkesinin kanun koyucu tarafından hatırlatılmasından ibaret olduğu yönünde, Hubert-Froidevaux, s. 117-118; hüküm hakkında ayrıntılı bilgi için bkz. De Poret, s. 123 vd.

168 Michel/ Schneider Kayasseh, s. 39; çeşitli hayvan kategorileri açısından ayrıntılı inceleme için, bkz. De Poret, s. 124.

169 Kavram hakkında genel bilgi için, bkz. Hubert-Froidevaux, s. 119-120.

170 Michel/ Schneider Kayasseh, s. 39.

171 Dördüncü fikranın uygulanabilir kılınması için en uygun yolun bu olduğu yönünde, De Poret, s. 125. Yazara göre böyle bir tedbir alınmaması halinde ilgililerin dava açma ihtimali zayıftır.

172 İsviçre hukukunda vakıf kurma ile yükleme yaratmanın karşılaştırılması için bkz. Hubert-Froidevaux, s. 116-117.

173 Uniform Trust Code, $\$ 408$ hükmünde, bu imkanı düzenlemektedir: “(a) A trust may be created to provide for the care of an animal alive during the settlor's lifetime. The trust terminates upon the death of the animal or, if the trust was created to
} 


\section{(v) Mülkiyet hakkına ilişkin diğer sınırlamalar}

Hayvanları koruma amacını taşıyan bazı kuralların ise daha kısıtlı alanlarda, belirli bazı insan davranışlarına sınırlamalar getirilmesi şeklinde oluştuğunu görmekteyiz. $\mathrm{Bu}$ düzenlemelerin ortak noktası, hayvanlar üzerinde mülkiyet kurulmasını ve mülkiyetten doğan yetkilerin kullanılmasını yer yer sınırlandırmalarıdır. Esasen çeşitli ülkelerde Hayvanları Koruma Kanunu biçiminde vücut bulan normların tamamı, çeşitli hayvan kategorileri altında, hayvanlara yapılacak müdahaleleri düzenlerken ve bazı filleri mutlak biçimde yasaklarken, aynı zamanda hayvanlar üzerindeki mülkiyet hakkının icrasını da sınırlandırmaktadırlar. Bu yasaklara aykırılık idari veya cezai yaptırımlar ${ }^{174}$ yanında hayvanın malikinden alınması gibi, mülkiyet hakkının sona ermesine yol açabilen sonuçlar da doğurabilmektedir.

Medeni kanunlar ile getirilen sınırlamalara ilişkin olarak ise Alman ve İsviçre hukuklarında yapılan iki düzenleme örnek gösterilebilir. Alman hukukunda malikin haklarını düzenleyen BGB §903'e 1990'da eklenen cümle, bu alanda genel bir kural ihdas etmiştir: Bir hayvanın maliki, mülkiyet hakkından doğan yetkilerini kullanırken, hayvanları koruyan normları dikkate alarak hareket etmek zorundadır. $\mathrm{Bu}$ hüküm ile, Alman Hayvanları Koruma Kanunu'nun ve hayvanları koruyucu diğer özel normların mülkiyet hakkına getirdiği sınırlamalar genel nitelikli bir norm ile desteklenmiş olmaktadır. İsviçre hukukunda karşımıza çıkan düzenleme ise, hayvanların ortak mülkiyet konusu olmaları halinde ortaya çıkabilecek paylaşım sorununa hayvanın menfaatini de hesaba katan yeni bir çözüm getirmeyi amaçlamıştır. Hayvanın mülkiyet konusu olabilmesi, paylı mülkiyet veya elbirliğiyle mülkiyet konusu da olabileceği anlamına gelir. İşte böyle bir durumda ortak mülkiyete son verilmesini gerektiren durumlarda hayvanın akıbetinin ne olacağ 1 sorusu ortaya çıkar. Bu sorun özellikle hayvanın paylı mülkiyet altında olduğunun tespit edildiği boşanma veya fiili ayrılık hallerinde, hayvanın mülkiyetinin terekenin unsurlarından biri olarak mirasçılara geçmesi halinde ve adi şirketlerin tasfiyesi halinde karşımıza çıkmaktadır ${ }^{175}$. İsviçre'de 2002'de yapılan revizyon, bu alanda da hayvanları diğer eşyalardan ayırma yolunu seçmiştir. İsviçre Medeni Kanunu'nun 651a maddesine göre, paylı mülkiyet konusu olan, ev ortamında yaşayan ve kazanç amacı güdülmeden bakılan bir hayvan üzerindeki mülkiyetin paylaşımına ilişkin bir ihtilaf çıkması

provide for the care of more than one animal alive during the settlor's lifetime, upon the death of the last surviving animal. (b) A trust authorized by this section may be enforced by a person appointed in the terms of the trust or, if no person is so appointed, by a person appointed by the court. A person having an interest in the welfare of the animal may request the court to appoint a person to enforce the trust or to remove a person appointed." Hüküm hakkında açıklama için, bkz. David M. English, The Uniform Trust Code (2000): Significant Provisions and Policy Issues, Missouri Law Review, C. 67, 2002, s. 168, dn. 138 .

174 Fransız hukuku, bu yasakların etkinliğini sağlamak için hayvanın iradi olarak terk edilmesini suç haline getirmiştir (“incrimination d'abandon volontaire”; bkz. Fransız Ceza Kanunu, m. 521-1). Fransa'da suç teşkil eden diğer fiiller için, bkz. Carius, Quel statut, para. no. 11; Almanya ve Avusturya'da suç haline getirilen bazı fiiller için, bkz. Lennkh, s. 312313.

175 Uygulama alanı için bkz. De Poret, s. 117; Barbara Graham-Siegenthaler, Art. 651a, Sachenrecht Art. 641-977 ZGB, Handkommentar zum Schweizer Privatrecht, ed. Breitschmid Peter/ Jungo Alexandra, 3. Bası, Schulthess, Zürih, 2016, s. 89. 
halinde, mülkiyet hakkı, hayvanların korunması alanında uygulanan kriterlere göre hayvanın kendisi için en iyi çözümü teşkil eden tarafa bırakılacak, hakim duruşma sırasında, hayvanın geçici olarak yerleştirilmesi de dahil olmak üzere her türlü geçici tedbiri alabilecektir. Her ne kadar velayet konusunu hatırlatıyor olsa da, hükmün hayvanın paylaşımı sorununu çocuğun velayetinin düzenlenmesine benzer biçimde çözdüğünü düşünmek düzenlemenin yapısına uygun düşmemektedir. Nitekim öncelikle, hükmün uygulanabilmesi için bir ihtilaf çıkması gerekmektedir; başka bir deyişle, velayet konusundan farklı olarak, tarafların anlaşması hakimin müdahale imkanını bertaraf etmektedir ${ }^{176}$. Öte yandan, mülkiyet kendisine birakılmayan tarafa bir ziyaret hakkının tanınması yetkisi de hakime tanınmamıştır ${ }^{177}$. Bununla beraber, ihtilaf halinde hayvanın taraflardan hangisine verileceği hususunda belirleyici olan yegane unsurun hayvanın üstün yararı olmas1 ${ }^{178}$, hükmün, hayvanın insanlar için arz ettiği önem nedeniyle değil, başlı başına bir değer olarak korunmasının amaçlandığını göstermektedir ${ }^{179}$. Hatta taraflardan hiçbirinin uygun yaşama şartlarını sağlayamayacağı kanısına varılırsa hakimin hayvanın satılması yoluyla paylı mülkiyetin ortadan kaldırılmasına karar verebileceği kabul edilmektedir ${ }^{180}$. Böylece görülmektedir ki, en azından paylaşım konusunda bir ihtilafın var olduğu hallerde, hayvanın menfaati burada da mülkiyet hakkına ilişkin sınırlayıcı bir unsur olarak kabul edilmiş olmaktadır.

\section{Türk Hukukundaki Durum}

Hukukumuzun hayvanların herhangi bir eşyadan farklı niteliklere sahip olduğu gerçeğini öteden beri dikkate almış olduğu, özel hukuk ilişkilerini düzenleyen normlar arasında uzun süredir hayvanlara ilişkin özel düzenlemeler bulunmasından anlaşılmaktadır. Örneğin satım sözleşmesinde borçlunun ayıba karşı tekeffülden sorumluluğu, satım konusunun hayvan olması halinde farklı bir düzenlemeye tabi tutulmuştur (TBK m. 220, 224). Keza, hayvanların sahipsiz hale gelmesi, -ve böylece bir başkası tarafından mülkiyet hakkı konusu yapılabilmesinin mümkün olması- diğer eşyalardan farklı biçimde düzenlenmiştir (TMK m. 768). Medeni Kanunumuz ayrıca hayvan satışlarında mülkiyeti saklı tutma sözleşmesinin yapılamayacağını ifade etmektedir (TMK m. 764/f. 2). Hayvan kirası da özel düzenlemeye tabidir (TBK m.

176 De Poret, s. 137.

177 Bu yönde, Michel/ Schneider Kayasseh, s. 34. Ancak yazarlar, hakimin her türlü ihtiyati tedbiri alma yetkisine ve davanın görülmesi sırasında her iki tarafın da halen malik olmalarına dayanarak ziyaret hakkını düzenleme yetkisinin bulunduğu görüşündedirler; aynı görüşte, bkz. De Poret, s. 142. Bazı yazarlar ise ziyaret hakkının karar sonrası için de tanınabileceği fikrindedirler; bkz. Graham-Siegenthaler, s. 88.

178 Uygulanabilecek kriterler için bkz. Graham-Siegenthaler, s. 88. Ev ortamında bakılan bir köpeğin, boşanma davası sırasında geçici tedbir niteliğinde taraflardan birine bırakılmasına ilişkin bir ihtilafta, İsviçre Federal Mahkemesi, olaydaki tüm faktörlere göre eşlerden hangisinin köpeğe daha iyi yaşam şartları sağlayacağının tespit edilmesi gerektiği yönünde karara varmıştır. Bu çerçevede, köpeğin kendisinde bırakılması için 11 yaşındaki çocuğunun köpekle olan manevi bağlarını ileri süren eşin bu argümanı, köpeğin menfaatleri gerekçe gösterilerek dikkate alınmamıştır (2. Hukuk Dairesi, 25 Ocak 2016,5A_826/2015)

179 Michel/ Schneider Kayasseh, s. 31; Graham-Siegenthaler, s. 87-88.

180 Michel/ Schneider Kayasseh, s. 32. 
376). Türk Ticaret Kanunu da taşıma sözleşmesinde taşınan eşyanın canlı hayvan olması hali için özel hükümler ihdas etmiş, bu durumu taşıyıcıyı sorumluluktan kurtarıcı bir unsur olarak da kabul etmiştir (TTK m. 878, 898).

$\mathrm{Bu}$ düzenlemelerin hepsi hayvanın canlı varlık olma niteliğini dikkate alsa da hiçbiri canlı varlığın kendine has ihtiyaçları nedeniyle korunması düşüncesine dayanmamaktadır. Başka bir deyişle, bu ayrık kuralların amacı hayvanların korunması değildir. Bu düzenlemeler, hayvanın canlı ve hareketli bir varlık olarak hareketsiz nesnelere nazaran yarattığı ilave risklerin dağılımı ve üremesi halinde oluşan ürünler üzerindeki mülkiyet hakkının belirlenmesi gereklerine dayanmaktadır. Hayvanları mülkiyet hakkının konusu, yani ekonomik araç sıfatıyla değerlendiren özel hukuk sistemimiz, bunların canlı birer varlık olmasını da bu durumun onların ekonomik işlevlerine etkisi düzleminde dikkate almıştır. Bu sistem içinde, hayvanları koruma amacına dayalı olarak, bu ekonomik işleve sınır çizmeyi amaçlayan özel hukuk düzenlemeleri çok sınırlı sayıdadır.

İcra ve İflas Kanunumuz, bu doğrultuda olduğu düşünülebilecek bir düzenleme içermektedir. Kanunun 83/b. maddesi uyarınca "Hayvan hacizlerinde, anaları tarafından beslenme ve bakılmaya muhtaç olan yavrular analarından ayrı haczedilemiyecekleri gibi bunların anaları da yavrularından ayrı haczedilemezler." Görüldüğü gibi, kanun hayvanların haczini yasaklamamış, ancak hayvanları bakıma muhtaç yavrularından koparmayı yasaklayarak, hayvanların eşya olma niteliğine, bu canlı varlıkların ihtiyaçlarını dikkate alan bir istisna getirmiştir. Sınai Mülkiyet Kanunumuzun 82. maddesinin 3. fikrası da "insan ya da hayvanlara önemli bir tıbbi fayda sağlamaksızın hayvanlara acı çektirebilecek genetik kimlik değiştirme işlemleri ve bu işlemler sonucu elde edilen hayvanlar" kategorisini patent verilmeyecek buluşlar arasında sayarak "önemli tıbbi fayda" olmaksızın hayvanlara acı çektirilmesine yönelik genetik kimlik değiştirme işlemlerini ekonomik fayda düzleminden çıkarmıştır. Bu iki düzenleme, hayvanları eşya olmaktan çıkarmamakla beraber, insanların hayvanlar üzerindeki tasarruf imkanına, hayvanların acı çekmeme yönündeki menfaatini ön plana alarak sınırlama getirmiştir.

Hukukumuzda hayvanların korunması açısından daha kapsamlı bir düzenleme 24 Haziran 2004 tarihli Hayvanları Koruma Kanunu ile getirilmiştir ${ }^{181}$. Kanunun ilk maddesi, kanunun amacını "hayvanların rahat yaşamlarını ve hayvanlara iyi ve uygun muamele edilmesini temin etmek, hayvanların acı, ıstırap ve eziyet çekmelerine karşı en iyi şekilde korunmalarını, her türlü mağduriyetlerinin önlenmesini sağlamak" olarak tanımlayarak doğrudan doğruya hayvanların menfaatlerini, kendi başına korunmaya mazhar menfaatler olarak korumayı hedeflemiştir. Kanunun, diğer ülkelerdeki muadillerine benzer şekilde, hayvanları çeşitli kategoriler altında

8159 sayılı kanun, 1 Temmuz 2004 tarihli Resmi Gazete'de yayımlanmıştır. 
sınıflandırmış olduğunu, en kapsamlı korumayı evcil hayvanlara getirdiğini ve en sınırlı şekilde korunan hayvanların deney hayvanları ile kesim hayvanları olduğunu görmekteyiz. Özellikle bu kategorilerdeki hayvanların yaşama hakkına getirilen sınırlamalara bakıldığında bu hakkın ilke olarak benimsendiğini söylemek güçtür; nitekim kanunun 4 (a) maddesinde hayvanların "bu Kanun hükümleri çerçevesinde yaşama hakkına sahip" olduğu hükme bağlanmıştır. Bununla beraber, her bir kategori altındaki hayvanlar üzerinde mülkiyet hakkının icrasıyla ilgili önemli sınırlamalar olduğunu da söylemek gerekir ${ }^{182}$.

Kanun bazı fiillerin icrasını mutlak olarak yasaklamıştır. Örneğin, ev ve süs hayvanları ile kontrollü hayvanlardan, doğal yaşama ortamlarına tekrar uyum sağlayamayacak durumda olanlarının terk edilmesi, beslenemeyeceği ve iklimine uyum sağlayamayacağı ortama bırakılması (m. 5/f. 7); güçten düşmüş hayvanların ticarî ve gösteri amaçlı veya herhangi bir şekilde binicilik ve taşımacılık amacıyla çalıştırılması (m. 6/f. 2), bir hayvanın acı, 1stırap ya da zarar görecek şekilde, film çekimi, gösteri, reklam ve benzeri işler için kullanılması (m. 10/f. 6); hasta, sakat ve yaşlı durumda bulunan veya iyileşemeyecek derecede ağrısı veya acısı olan bir hayvanın usulüne uygun kesmek ya da ağrısız öldürme amacından başka bir amaçla birine devredilmesi, satılmas1 veya alınması (m. 10/f. 8) yasaktır. Bunlara ilaveten kanunun 14. maddesinde onbir bent halinde sayllan fiiller "hayvanlarla ilgili yasaklar" olarak nitelendirilerek yine mutlak olarak yasaklanmıştır. Kanun ayrıca "ticarî amaç güdülmeden bilhassa ev ve bahçesi içerisinde bakılan ev ve süs hayvanları"nın sahiplerinin borcundan dolayı haczedilemeyeceğini de hükme bağlamıştır (m. 5/f. 5). Bazı fiillerin icrası ise yetkili makamların iznine bağlanmış durumdadır. Örneğin, hayvanların bilimsel çalışmalarda deney hayvanı olarak kullanılması, başka bir seçenek olmaması şartına ve hayvan deneyi yapan kurum ve kuruluşlarda kendi bünyelerinde kurulmuş ve kurulacak etik kurulların iznine bağlanmıştır (m. 9/f. 3,4) ${ }^{183}$. Yine hayvanların ticarî amaçla film çekimi ve reklam için kullanılması ile ilgili hususların, usul ve esasları Çevre ve Orman Bakanlığı'nın çıkaracağı yönetmelikle belirlenecek izne tabi olacağ 1 (m. 10/f. 5) $)^{184}$ ve folklorik amaca yönelik, şiddet içermeyen geleneksel gösterilerin de Çevre ve Orman Bakanlığı'nın uygun görüşü alınarak il hayvanları koruma kurullarından izin alınmak suretiyle düzenlenebileceği (m. 11/f. 2) hükme bağlanmıştır. Bu izin mekanizmalarının ne kadar etkin işletilebildiği sorusu elbette tartışmaya açıktır ve ampirik bir çalışma üzerinden değerlendirmeye varmayı gerektirir. Bununla beraber toplumsal olarak hayvanlara verilen değer arttıkça bu süreçlerin kendilerinden beklenen sonuçları verme yönünde gelişme göstereceği de muhakkaktır.

\footnotetext{
$182 \mathrm{Bu}$ kanun ve ilgili mevzuat çerçevesinde hukukumuzdaki durumun incelenmesi için bkz. Ertaş, Çevre Hukuku, s. 478 vd.

183 Bkz. 13.12.2011 tarihli, 28141 sayılı Resmi Gazete'de yayımlanan Deneysel ve Diğer Bilimsel Amaçlar İçin Kullanılan Hayvanların Refah ve Korunmasına Dair Yönetmelik.

184 Bkz. 12.05.2006 tarihli, 26166 sayılı Resmi Gazete'de yayımlanan Hayvanların Korunmasına Dair Uygulama Yönetmeliği.
} 
Bir yandan denetim mekanizmalarının etkisizliğ $1^{185}$, öte yandan kanun hükümlerine aykırılığın yaptırımı olarak cüz’i miktarda idari para cezasının öngörülmüş olması (m. 28) kanunun işlevselliğini önemli ölçüde azaltmaktadır. Ancak mülkiyet hakkı açısından önemli bir sonuç, 24. madde ile öngörülmüştür. Hükme göre, kanunun hayvanları korumaya yönelik hükümlerine aykırı hareket eden ve bu suretle bulundurduğu hayvanların bakımını ciddi şekilde ihmal eden ya da onlara ağrı, acı veya zarar veren kişilerin denetimle yetkili merci tarafından hayvan bulundurması yasaklanacak ve hayvanlarına el konulacaktır. Ayrıca söz konusu hayvan yeniden sahiplendirilecek ya da koruma altına alınacaktır. Kanunda öngörülen yaptırımların yetersizliği, halihazırda kanunlaşmayı bekleyen ve temel olarak yaptırımları arttırarak caydırıcılığı sağlamayı hedefleyen ${ }^{186}$ bir tasarının hazırlanmasına neden olmuştur.

Hayvanları Koruma Kanunu ve bağlı mevzuat ile yer yer getirilmiş sınırlamaların ötesine geçen, hayvanın hukuki statüsünün yeniden ele alınmasını sağlayan ilkesel nitelikteki düzenlemelere hukukumuzda henüz yer verilmemiştir. Bu çerçevede bazı yazarlar hukukumuzda eşyanın canlı veya cansız olması açısından ayrım yapılmıyor olmasını bir eksiklik olarak nitelendirmiştir ${ }^{187}$. Bazı yazarlar, hayvanları korumaya yönelik bir düzenlemenin bulunmasının onların eşya statüsünü değiştirmediğini, hukukumuz açısından hayvanın eşya olmadığı sonucuna varabilmek için diğer bazı ülkelerde olduğu gibi Medeni Kanun değişikliğine gidilmesinin zorunlu olduğunu savunmuşlardır ${ }^{188}$. Bununla beraber Hayvanları Koruma Kanunu'ndaki düzenlemelerin hayvanın artık eşya olarak nitelendirilemeyeceği sonucuna götürdüğünü savunan yazarlar da vardır ${ }^{189}$.

Her hâlükârda, hayvanlara uygulanacak normların kapsamına bakıldığında, ülkemizdeki hukuki tablonun yukarıda incelenen ülkelere kıyasla daha geleneksel nitelite olduğu görülmektedir. Bununla beraber, bazı geleneksel mekanizmalar da, hayvanların daha etkin biçimde korunması amacıyla kullanılabilir. İsviçre hukukunda mirasbırakanın yükleme yaratmasında ilişkin olarak yukarıda değindiğimiz hükümler ${ }^{190}$ bizim hukukumuzda da mevcuttur. TMK'nın 515. maddesine göre, "Mirasbirakan, ölüme bağlı tasarruflarını koşullara veya yüklemelere bağlayabilir. Tasarruf hüküm ve sonuçlarını doğurduğu andan itibaren, her ilgili koşul veya yüklemenin yerine getirilmesini isteyebilir.” Bir hayvanın bakımına ilişkin yükleme, maddenin ikinci ve

\footnotetext{
185 Bu konudaki eleştiriler için bkz. Arıkan, s. 220, s. 225.

186 Uyumaz, s. 176.

187 Ertaş, Eşya Hukuku, s. 7; Esener/Güven, s. 44, dn. 12.

188 Aksoy Dursun, s. 187-188.

189 Hayvanları Koruma Kanunu'nun hayvanlara yaşama hakkı tanımasından hareketle, hayvanların eşya olmadığının kanunla hükme bağlanmış olduğunu savunulmaktadır; bkz. Oğuzman/ Seliçi/ Oktay-Özdemir, s. 10. Diğer bir görüşe göre, bu kanunun getirdiği düzenlemeler ile birlikte hayvanların hukuki durumu özel olarak düzenlenmiş ve ve hayvanlar artık eşya olmaktan çıkarılmış bulunmaktadır. Bu düzenleme sonucu hayvanların eşya olarak nitelendirilmesi mümkün değilse de yeni bir hukuk süjesi kategorisinin getirilmiş olduğunu söylemek de mümkün değildir. Hayvan yine hukuk objesi olarak kalmakta, üzerinde hak kurulabilmektedir; bkz. Antalya, s. 24.

190 Bkz. yuk. III-A-1-b (v).
} 
üçüncü fikralarında getirilen koşullara uygun olduğu, yani hukuka veya ahlâka aykırı olmadığı, anlamsız veya yalnız başkalarını rahatsız edici nitelikte de görülemeyeceği ölçüde bazı malvarlığı değerlerinin belirli hayvanlar veya hayvan grupları için kullanılabilmesini sağlar. Maddede belirtilen "ilgililer"in çevresine, yüklemenin yerine getirilmesinde dolaysız veya dolaylı, maddi ve manevi menfaati bulunan herkes girecek ${ }^{191}$, böylece bir hayvansever dahi yüklemenin yerine getirilmesini talep edebilecektir ${ }^{192}$. Her ne kadar kanunumuz hayvanların mirsçı olarak tayin edildiği tasarrufların akıbetini açıkça düzenlememiş olsa da, İsviçre hukukuna 2002'de dahil edilen ve bu tasarrufları yükleme olarak geçerli sayan sonuca, favor testamenti ilkesi ve tahvil kurumu yoluyla da ulaşılabilinir ${ }^{193}$. Hayvanlara verilen zararın sahipleri için manevi tazminat alacağı doğurması da hukukumuzda TBK'nın 58. maddesi tahtında, İsviçre'deki muadili 49. maddeden daha kolaylıkla kabul edilebilir. İsviçre hukukunda ihlalin belli bir ağırlıkta olması, manevi tazminat sorumluluğunun doğmasında etkili olan bir koşuldur. Hâlbuki Türk hukukunda manevi tazminat talebi, ihlalin ağırlığı koşuluna dayanmamakta, şartların oluşup oluşmadığının tayininde hakime daha geniş bir hareket alanı bırakılmaktadır ${ }^{194}$. Başka bir deyişle bugün hayvanlarla ilgili olarak İBK'nın 43. maddesinde düzenlenmiş olan manevi zararın tazmini imkanının, bizim hukukumuzda TBK'nın 58. maddesi altında benimsenebilmesinin önünde bir engel bulunmamaktadır.

\section{B. Hayvanların Hukuki Statüsüne İlişkin Çözüm Yolları}

Yukarıda ana hatlarıyla gördüğümüz düzenlemeler, insan davranışlarının hayvanların kendi yaşamsal menfaatleri lehine gittikçe sınırlandırıldı̆̆ını göstermektedir. Yapılan hukuki düzenlemeler yoluyla hayvanlar, maliklerine karşı korunan ve maliklerinin refahını sağlamakla yükümlü olduğu varlıklar olarak tanınmış, böylece kanunun bir başka kişinin veya kamunun menfaatleri için değil, bizzat kendi menfaatleri için koruma amacını güttüğü tek eşya haline gelmiştir ${ }^{195}$. Hayvanlara karşı modern hayattaki anlayışımız saygı ve içsel değer gibi, hukukun yakın zamana kadar gözünü kapadığı ve üzerinde kurulan mülkiyet hakkı ile bağdaştırılması güçlük arzeden yeni parametreleri de içermektedir ${ }^{196}$. Bu şartlar altında hayvanların hukuki statüsünün ne olduğu ve ne yönde evrilmesi gerektiği konusunda farklı görüşler ileri sürülmüştür. Bazı yazarlar hayvanların hukuken kişi veya kişi benzeri olarak (1),

\footnotetext{
191 Rona Serozan/Baki İlkay Engin, Miras Hukuku ve Uygulama Çalışmaları, 5. Bası, Seçkin Yayıncılık, Ankara, 2018, s. 373.

192 Idem, s. 375.

193 Kedi veya köpeğin mirasçı olarak tayin edildiği vasiyetin, farazi iradeye dayalı çevirici yorum yoluyla mirasçılara yüklenecek bir yüklemeye dönüştürülerek geçerli tutulabileceği yönünde, bkz. Serozan/Engin, s. 419.

194818 sayılı Borçlar Kanunu'nun 49. maddesi, 1988 tarihli ve 3444 sayılı kanunla değiştirilmeden önce, manevi tazminata hükmedilebilmesi için zararın ve kusurun ağırlığını şart koșmaktaydı. Bununla beraber halihazırda yürürlükte olan metne göre de her türlü ihlalin tazminat talebini haklı gösteremeyeceği kabul edilmektedir. TBK m. 56'da manevi tazminat belirlenirken göz önünde bulundurulacağı açıkça ifade edilen "olayın özellikleri” ölçütünün BK m. 58 için de uygulanması ve bu çerçevede ihlalin ağırlığının hakimin takdir yetkisi çerçevesinde değerlendirilebileceği yönünde, bkz. Hülya Atlan, Manevi Zararı Tazmin Yolları, On İki Levha Yayıncılık, 2015, s. 139.

195 Antoine, s. 27.

196 Idem, s. 28
} 
bazıları kişi ile eşya arasında bir ara kategori olarak (2) kabul görmeleri gerektiğini, bazıları ise hayvanların eşya olarak nitelendirilmekle birlikte özel bir eşya statüsüne sahip olmaları gerektiğini (3) ileri sürmüştür.

\section{Hayvanların Kişi veya Kişi Benzeri Olarak Kabul Edilmeleri}

Hayvanların, kendilerini korumak için insanlara yüklenmiş ödevlerin yararlanıcıları oldukları şüpheden uzaktır. Pekiyi hayvanlara karşı ahlaki ödevlerin hukuki ödevlere doğru evrilmesini sağlayan düşünsel gelişmenin, bu hukuki ödevlerden hak sahipliğine doğru gidilmesini sağlayacak seviyeye geldiği de söylenebilir mi? Hayvanların korunmasını sağlayan hukuk kurallarından yola çıkarak, hayvanların medeni planda artık kişi olarak kabul edilebileceği sonucuna varılmasının mümkün olup olmadığ1, hayvanın hukuki statüsünün merkezinde yer alan sorundur. İşte hayvanların hukuki kişiliğe sahip olması gerektiğini ileri sürenler, bu durumun hem mümkün, hem de gerekli olduğunu savunmaktadırlar. Hayvanların hakların öznesi olarak kabul edilmelerinin sebeplerine ve yöntemlerine ilişkin çok çeşitli görüşler ileri sürülmüştür. Bu görüşlerden öne çıkan bazılarını kısaca aktarıp, ortak noktalar konusunda bir senteze varmaya çalışacağız.

Faydacı filozof Bentham, daha 18. yüzyılda, hayvanların eşya statüsüne "indirgenmesini”, onların menfaatlerini göz ardı eden eski zaman hukukçularının duyarsızlığına bağlamış, hayvanların onlardan tiranlık yoluyla alınmış olan haklara kavuşacağ1 günlerin geleceğini söylemiştir ${ }^{197}$. Bentham'a göre bir varlığın hak sahibi olarak tanınması için sorulması gereken soru bu varlığın akıl yürütebilmesi veya konuşabilmesi değil, hislere sahip olup olmamasıdır ${ }^{198}$. Bentham'ın ve benzer çizgideki düşünürlerin görüşlerinin yaygınlık kazanması, hayvan refahı kavramının gelişmesi ve hayvanlara eziyet veren muamelelerin peyderpey yasaklanması yönünde etki doğurmuştur. 1970'lere gelindiğinde ise hayvanların refahının sağlanması düşüncesi yetersiz görülmeye başlanmıştır. Bu yıllarda "hayvan hakları" teorisinin gelişmesi ile birlikte, hayvanların eşya statüsünden çıkarılarak kişi olarak kabul edilmelerine ilişkin somut öneriler çeşitli yazarlarca ileri sürülmeye başlanmıştır ${ }^{199}$.

Amerikalı hukukçu Francione'ye göre, insanlara birer araç olarak görülmeme hakkının tanındığı bir düzlemde, hissetme yetisi olan hayvanlara da aynı hakkın tanınmaması için hiçbir makul gerekçe bulunmamaktadır ${ }^{200}$. Yazar, bu eşitliğin sağlanması için hukuki planda önemli olan unsurun hayvanlara hak kazandırılması

\footnotetext{
197 Jeremy Bentham, An Introduction to the Principles of Morals and Legislation, 1789, online edition by The University of Adelaide Library, 2014, https://ebooks.adelaide.edu.au/b/bentham/jeremy/morals/index.html, E.T. 21.11.2018, Bölüm 19, para. no. 4

198 Ibid. Ancak yazar, insanların hayvanları gıda olarak tüketmeleri ve kendilerine saldıran hayvanları öldürmeleri için geçerli gerekçeler olduğunu, faydacı felsefesinin ilkelerini uygulayarak, tartımcı bir yaklaşımla açıklamaktadır.

199 Genel bilgi için, bkz. yuk. dn. no. 14.

200 Hissetme yetisinin menfaat sahibi olmanın zorunlu koşulu olduğu yönünde, Francione, Debate, s. 15.
} 
değil, hayvanların mülkiyet konusu olmaktan tamamen çıkarılması ve vegan bir yaşam tarzının benimsenmesiyle hayvan kullanımının tamamen ortadan kaldırılması olduğunu ifade etmiştir ${ }^{201}$. Hayvanların sahip olması gereken temel hak, tıpkı insanlarda olduğu gibi, mülkiyet konusu olmama yönünde bir haktır ${ }^{202}$. Eşyalar amaç değil, sahiplerinin bazı amaçlara ulaşmaları için var olan araçlardır; dolayısıyla eşya olarak konumlandırılan hayvanın bazı menfaatleri korunsa dahi bu menfaatler insanların menfaatleri gibi taviz verilemez şekilde korunmayacak, bu nedenle de sağlanan koruma hiçbir zaman gerçek anlamda hak teşkil etmeyecektir ${ }^{203}$. Yazar bu yönde adım atmaktan kaçınan hayvan refahı hareketinin ve buna bağlı yasal düzenlemelerin insanları hayvanları sömürme konusunda daha rahat kılma amacını güttügünü ileri sürmüştür ${ }^{204}$. Francione her ne kadar açıkça hukuki kişilik kavramından bahsetmiyor olsa da yazarın hayvanların eşya kategorisinden tamamen çıkarılmasını, hayvan haklarının tesis edilmesinde ilk adım olarak nitelendirmesi, hayvanların son tahlilde hak öznesi olmaları yönündeki bir hukuki gelişime işaret ettiğini göstermektedir.

Amerikalı hukukçu Steven Wise da hayvanlara kişilik kazandırılmasını ve hayvanların bazı temel haklara kavuşturulmasını savunmaktadır. Ancak Wise, bu statüye kavuşturulması gereken hayvanların tayininde hayvanın hissetme yetisini esas almamakta, bu durumu da pratik gereklerle açıklamaktadır: Yazara göre, bu kriter, gıda olarak tükettiğimiz hayvanlar için de temel haklar tanınmasını zorunlu kılacak ve hayvan haklarının gelişimini tamamen durduracaktır ${ }^{205}$. Yazar, ikna kabiliyetinin daha yüksek olduğunu düşündüğü başka bir kriterden yola çıkarak, kişilik tanınması gereken hayvan çerçevesini daraltmaktadır: Hayvanların temel haklara kavuşturulmasında temel kriter, bir şey arzulayabilecek kadar kompleks bir zihinsel yapıya sahip olmak, bir arzuya ulaşma için iradi olarak hareket edebilmek, kendi varlığının bilincinde olmak unsurlarından oluştuğunu ifade ettiği "pratik otonomi”ye sahip olma kriteridir"206. Otonomi kriteri ve bunun baz1 hayvanlarla insanlar arasında paylaşılan bir unsur olması, aynı durumda olanlara eşit davranılmasını gerektiren eşitlik ilkesi uyarınca da hayvanlara insanlarla eşit muamele yapılmasını sağlamalıdır, meğer ki hayvan ile insanın, otonomi sahibi olma yönündeki benzerliklerine rağmen farklı canlılar olarak sınıflandırılması ahlaki gereklere uygun kriterlerle açıklanabil $\sin ^{207}$. Böylece Wise, hayvanların otonomi

\footnotetext{
${ }^{201}$ Idem, s. 22-24. Hukukumuzda da Başpınar, hayvanların mülkiyet hakkının ve alışverişin konusu oldukları sürece eşya olmaktan başka bir niteliğinin bulunamayacă̆ını, hayvanların eşya olmaktan çıkarılması isteniyorsa yapılması gerekenin, onların alışverişe konu olamayacaklarının kabul edilmesinin olduğunu belirtmiştir (Başpınar, s. 1385).

202 Gary L. Francione, Rain Without Thunder-The Ideology of the Animal Rights Movement, Temple University Press, 1996, s. 178; Francione, Animal Rights, s. 441-443.

${ }^{203}$ Francione, Rain Without Thunder, s. 180.

204 Francione, Debate, s. 51. Refah teorisinin ayrıntılı eleştirisi için, ayrıca bkz. Francione, Rain Without Thunder, özellikle s. $110 \mathrm{vd}$.

205 Wise, Nonhuman Rights, s. 1286.

206 Idem, s. $1283 \mathrm{vd}$

207 Wise, Nonhuman Rights, s. 1286-1287
} 
kriterini sağladıkları ölçüde insanlara benzer bir muameleye tabi tutulmaları ve temel haklara sahip olmaları fikrini savunmuş olmaktadır. Görülmektedir ki Wise, eşitlik ilkesinden yola çımakta ancak eşitlik durumunu hissetme yetisinden daha dar alanda etki doğuran bir kritere dayandırmaktadır. Yine aynı ilkeden yola çıkan Kanadalı hukukçu Giroux, temel hakları hayvanlara daha geniş bir tür yelpazesi içinde tanımaktadır. Bu görüşe göre, menfaat teorisine dayalı hak anlayışının, eşitlik ilkesi ile birlikte okunması bizi şu sonuca götürür: Ĕger bir bireye bazı menfaatlerini korumak için haklar tanıyorsak, bu hakları, aynı menfaatlere sahip tüm bireylere tanımak hususunda ahlaki bir yükümlülük altında bulunuruz, meğer ki bu eşitliği sağlamamak için ahlaken geçerli bir sebebimiz olsun ${ }^{208}$. Tüm duyarlı varlıklar acı çekmeme ve yaşamaya devam etme yönünde bir menfaate sahip olduklarından fiziksel şiddete maruz kalmama ve öldürülmeme yönündeki temel haklardan sadece insanların değil, tüm duyarlı varlıkların yararlanabilmesi gerekir ${ }^{209}$.

İsviçre'de Stucki, İsviçre hukukunun ulaştı̆̆ı noktanın halihazırda hayvanları hak öznesi olarak konumlandırmakta olduğunu savunmaktadır: Hayvanın onurunun hukuken kabul edilen bir değer olması, hayvanın diğer eşyalardan farklı hükümlere tabi olması ve kendisi için korunmaya mazhar menfaatlerinin bulunduğunun kabulüne işaret eden diğer faktörler, hayvanın nesne olmaktan uzaklaşması ve fiilen özne olma niteliğinin güçlendirilmesi anlamına gelmektedir ${ }^{210}$. Yazara göre, kendi başına bir amaç olarak görülebilen şeyler için hak öznesi statüsü geçerli olmalıdır; zira hakların konusu olarak kabul edilen varlıklar, amaç olarak değil, araç olarak kullanıma tabi bulundukları için bu statüde değerlendirilmektedirler ${ }^{211}$. Hayvanlar halihazırda eşya olmayan (Nicht-Objekt), kişi benzeri (Quasi-Subjekt) varlıklar olarak hukuk düzenince kabul edilmektedir ${ }^{212}$ ve bu fiili duruma uygun olarak hukuki kişilik de kendilerine tanınmalıdır ${ }^{213}$. Bu görüş̧e göre hayvanlara tanınacak kişilik, tüzel kişilerinkine benzer şekilde konumlandırılmalı, hayvanlar, acı çekmeme ve yaşama gibi doğalarına uygun olan haklarla sınırlı bir kişiliğe sahip olmalıdır ${ }^{214}$. Bu nedenle hukuki kişiliği gerçek kişiler ile tüzel kişiler olarak iki kategori halinde sınıflandıran "tertium non datur" ilkesinden ayrılarak, bunların yanında "hayvan kişi” nin de, kendine özgü haklarla donatılmış biçimde var olduğunu kabul etmek gerekmektedir ${ }^{215}$.

\footnotetext{
208 Giroux, s. 132.

209 Idem, s. 133; hayvanların acı çekmeme menfaati ile ilgili olarak, bkz. s. 133 vd; öldürülmeme menfaati ile ilgili olarak, bkz. s. 149 vd. Hayvanların ölüm kavramını ve kendi ölümlerinin sonuçlarını idrak etme yetisine sahip olmadıkları düşüncesi, öldürme eyleminin, acı vermeden gerçekleştirilmesi halinde hayvanı strese ve acıya sürüklemediği fikrinin doğmasına, dolayısıyla hayvanın yaşamaya devam etme yönünde bir menfaatinin bulunmadığının kabul edilmesine neden olmaktadır. Yazar bu görüşleri eleştirmektedir, bkz. özellikle $162 \mathrm{vd}$.

210 Stucki, Die «tierliche Person», s. 300.

211 Idem, s. 306.

212 Idem, s. 297.

213 Idem, s. 307.

214 Stucki, Rechtstheoretische Reflexionen, s. 168.

215 Stucki, Die «tierliche Person», s. 316.
} 
Fransa'da hayvanlara kişilik kazandırılması gerektiğini savunan görüşlerin, 20. yüzyılın başında hukuki kişilik kavramını insan kavramından ayırarak tanımlamış olan Demogue'dan esinlenmiş olduğu söylenebilir. Demogue, hak öznesi kavramını, hukukun amacı ile ilişkilendirir ve hak sahibinin tespitinde hakkın ne olduğu sorusundan yola çıkar ${ }^{216}$. Yazara göre hukuk kuralının amacı, bazı maddi veya manevi unsurlardan istifade edilebilmesini, bazı imtiyazlara kavuşulmasını sağlamaktır ${ }^{217}$. Hukuk kuralı iradeyi değil, menfaatleri korumayı amaçlamaktadır; irade unsuru, olsa olsa bir hakkın icra edilebilmesi için gerekli olabilir ${ }^{218}$. Böylece yazar, hakları bizzat kullanabilme imkanının sadece hukuki işlem yapabilme yetisi olan kişilere ait olmasına rağmen, haklardan yararlanabilme imkanının böyle bir sınırlamaya tabi olmadığını, dolayısıyla insan olma çerçevesinin de ötesine geçmesinin mümkün olduğunu savunmuştur ${ }^{219}$. Hak kavramının bir menfaati korumaya yönelmiş olması, irade unsurunun ise hak ehliyeti değil, fiil ehliyeti açısından önem taşıması nedeniyle, duyarlılık sahibi, dolayısıyla acı çekmesi mümkün olan tüm canlılar, geçici veya sürekli olarak temyiz kudretinden yoksun bulunsalar dahi hak öznesi olmaya kabildirler ${ }^{220}$. Fransız hukukçu Marguénaud, Demogue’un görüşünü modern bir platforma taşıyarak hayvanların hukuki kişiliğine ilişkin tezini "teknik kişilik" kavramı çerçevesinde şekillendirmiştir. Marguénaud, hayvanlara, insanların sahip olduğuna paralel bir kişilik değil221, hayvanların menfaatlerini gruplandırmayı sağlayan, tüzel kişilerinkine benzer "teknik" bir hukuki kişilik tanınması gerektiği görüşündedir ${ }^{222}$. Nitekim hayvanlar da, tıpkı tüzel kişilik tanınan topluluklarda olduğu gibi, onlar üzerinde hak icra edenlerin menfaatlerinden ayrı, kendilerine has menfaatlere sahiptirler ve bunlar hukuk düzenince de korunmaktadır. Hatta yazar, Fransa' da tüzel kişiler hukukunda kabul gören, meşru menfaatlerinin korunması için ortak bir ifade imkanına sahip tüm gruplara, kanun hükmü olmaksızın hukuki kişilik tanıyan "teknik gerçeklik" teorisinin uygulanması ile, en azından, hem kendine has menfaatleri olan hem de malikleri veya dernekler aracılığılyla bunları dile getirme imkanları bulunan ev hayvanlarının şimdiden bu teknik kişiliğe sahip olduğunun söylenebileceğini savunmaktadır ${ }^{223}$. Chareix'e göre de Marguénaud'nun geliştirdiği, hayvanlara insanlarınkine benzemeyen, sınırlı bir kişilik tanıma çözümü, hayvanların

\footnotetext{
${ }_{216}$ René Demogue, "Le sujet de droit", Revue Trimestrielle de Droit Civil, 1909, s. 615

17 Idem, s. 615-616.

18 Ibid.

19 Idem, s. 620-621.

20 Idem, s. 620.

221 Jean-Pierre Marguénaud, "Ni personne, ni objet, l'animal", Bulletin de l'Académie Vétérinaire de France, C. 69, 1996, s. 21-22. Yazar, bu tür bir paralelliğin hayvanlara bir şey kazandırmadığını, insanlara ise çok şey kaybettireceğini savunmuștur. Her türlü hayvan deneyinin yasaklanması, herkesin vejetaryen olmaya zorlanması, hayvan nüfusunun tehlikeli biçimde çoğalmasına karşı tedbir alınamaması, insan topluluğunun hayatta kalamaması sonucunu doğuracaktır. Öte yandan hayvanların insan seviyesinde korunması insanların hayvan seviyesinde düşünülmesi tehlikesini de doğurabilir.

222 Idem, s. $16 \mathrm{vd}$.

223 Idem, s. 22-23.
} 
gerçek kimliğini yadsımayan bir çözümdür ${ }^{224}$ ve halihazırda uygulanmakta olan sistemden esaslı bir değişikliğe gidilmesine de neden olmayacaktır. Nitekim hayvanlar fiilen koruyucu normlardan yararlanmaktadırlar; kendileri için kurgusal bir kişiliğin yaratılması, malvarlığı haklarına sahip olma gibi alanlarda kendini gösteren teknik engelleri, koruma amacına uygun olarak kaldırabilecektir.

Yine benzer bir çizgide hareket eden Amerikalı hukukçu Favre, hayvanları "yaşayan mülkiyet" olarak özel bir kategoride değerlendirmeyi önermiştir. Her ne kadar yazarın önerdiği isim hayvanların eşya olarak konumlandırılmasını çağrıştırsa da, hayvanların hak öznesi olabileceği yönündeki görüşü ve hayvanlara tanınmasının gerekli olduğunu gördüğü hakların kapsamı, hayvanlara bu haklarla sınırlı olarak "sınırlı hukuki kişilik" tanınması sonucuna varılmasını zorunlu kılmaktadır ${ }^{225}$. Nitekim yazar, yaşayan mülkiyet kavramı çerçevesinde hayvanların sadece zarar görmeme yönünde haklarla değil, ilgi görme, yaşama alanına sahip olma, mülkiyet hakkı sahibi olma, sözleşme yapma ve temel menfaatlerini zedeleyen gerçek kişilere karşı dava açma gibi haklarla da donatılması gerektiğini savunmuştur ${ }^{226}$.

Türk öğretisinde de hayvanlara hak ehliyeti tanınması gerektiği görüşü, Sungurbey tarafından dile getirilmiştir ${ }^{227}$. Yazara göre hayvanlara kişilik hakları tanınması başka şey, bunların hayvanlar adına ne şekilde kullanılacağı başka şeydir. Burada temel sorun, ilke olarak bu yeteneğin ve hakların tanınması sorunudur. Yoksa bu hakların nasıl olsa kimi kişi ve kuruluşlarca kullanılacağı bahane edilerek, bu yeteneğin ve hakların tanınması engellenemez ${ }^{228}$. Koçhisarlıoğlu ve Erişgin'e göre ise hayvan, eşya ile kişi arasında bir ara kategori olarak nitelendirdikler, "kısmi hukuk öznesi" olarak görülmesi gereken bir varlık haline gelmiştir. Yazarlar, tüzel kişilerin ve tam ehliyetsiz ile sınırlı ehliyetsiz kişilerin de aslında kısmi hukuk öznesi olduğunu, hayvanlara da bu statüyü tanımaya herhangi bir engel bulunmadığını ifade etmişlerdir ${ }^{229}$.

Hayvanlara hukuki kişilik tanınmasına ilişkin görüşler, her zaman açıkça dile getirilmeseler de mantıksal açıdan zorunlu olan bazı ortak önermelere dayanmaktadır. Bu önermeler aşağıdaki gibi sıralanabilir:

Menfaat teorisine dayalı hak anlayışının benimsenmesi. Hayvanlara sınırlı da olsa hukuki kişilik kazandırılması düşüncesi, irade sahibi olmayan varlıkların da hak sahibi olarak kabulünü gerektirir. Kişi, hakkın öznesidir; başka bir deyişle, hukuken kişi olarak kabul görmek için hak sahibi olarak nitelendirilmek gerekir. Bu noktada, hakk1

\footnotetext{
224 Fabien Chareix, "L'animal, entre personne et chose?", Revue de synthèse, C. 120, S. I. 4, 1999, s. 529

225 Favre, s. 1061 vd.

226 Ibid.

227 İsmet Sungurbey, Hayvan Hakları-Bir İnsanlık Kitabı, İ. Ü. Basımevi ve Film Merkezi, İstanbul 1992, s. 72 vd., özellikle s. 81 .

228 Idem, s. 81

229 Cengiz Koçhisarlıŏglu/Özlem Söğütlü Erişgin, "Hayvanın Hukuki Konumu”, Yaşar Üniversitesi Elektronik Dergisi, Prof. Dr. Aydın Zevkliler'e Armağan, C. 2, 2013-Özel say1, s. 1721-1722.
} 
meydana getiren kurucu öğeler, kimlerin hak sahibi olarak nitelendirilebileceğini de belirlemektedir. Hak kavramının kurucu öğeleri ise, hakların gördüğü işlevi belirleme sorununu esas alan ve rakip teoriler olarak ifade edilen ${ }^{230}$ "irade teorisi" ile "menfaat teorisi"ne verilen ağırlığa göre farklı şekillerde belirlenebilmektedir ${ }^{231}$. İrade teorisi, hak sahibinin kendisine sağlanan hukuki korumadan yararlanma veya yararlanmama yönündeki iradesini hak kavramının merkezine yerleştirirken, menfaat teorisi, hak sahibinin menfaatlerini merkeze almaktadır ${ }^{232}$.

İrade teorisi uyarınca hak sahibi olmak başka kişilerin davranışları üzerinde kontrol sağlayan bir seçim olanağına sahip olmaktır: Hakkın amacı, sahibine, örneğin, bir sözleşmenin cebren ifasını sağlama veya sağlamama yollarından birini seçerek bir başkasının ödevlerini yerine getirmesini, yani belirli bir şekilde davranmasını veya davranmaktan kaçınmasını kontrol edebilme olanağı sunmaktır ${ }^{233}$. $\mathrm{Bu}$ irade unsuru, hukuki korumadan yararlanmanın bireyin isteğine bırakıldığını vurgular, bireye kendi isteği dışında bir menfaatin dayatılamayacağını gösteririr ${ }^{234}$. $\mathrm{Bu}$ itibarla çağdaş sistemlerin hakların kullanımına ilişkin bazı mekanizmalarının doğrudan doğruya irade teorisine dayandığı görülmektedir: Kişiler, haklarını kullanıp kullanmamakta serbesttirler, hakları üzerinde tasarruf edebilir, kural olarak haklarından feragat edebilirler ${ }^{235}$; bağışlama ve borçtan ibranın tek taraflı işlem değil de, yararlananın iradesini gerektiren sözleşmeler olması da yine iradenin etkisine işaret eder ${ }^{236}$. Hak kavramının, bu hakka karşllık gelen ödev üzerindeki kontrol yetkisi olarak tanımlanması, kimlerin hak sahibi olacağına ilişkin bir koşulu da içinde barındırmaktadır: Başkalarının ödevlerini kontrol edebilecek yetkileri kullanabilecek bir zihinsel yetkinliğe sahip olmak, irade teorisi uyarınca hak sahibi olmak için zorunlu bir nitelik taşımaktadır ${ }^{237}$. Böylece kendi iradelerini rasyonel biçimde oluşturarak ortaya koyabilme, yani hakkın kendilerine tanıdığı kontrol imkanını kullanma kapasitesinden yoksun olanların, örneğin küçükler, akıl hastaları gibi temyiz kudreti olmayanların hak sahipleri olarak görülmemeleri gerekir ${ }^{238}$. Oysa pozitif hukukta, bu alanda başka ilkeler benimsenmekte ve böylece irade teorisinin etkisine de bir sınır çizilmektedir. Temyiz kudreti olmayan insanlar da, herhangi bir seçim yapabilme yetisine sahip olmamalarına rağmen kişi olarak tanınmakta ${ }^{239}$, sağlıklı bir iradesi olmayan, ayırt etme gücünden yoksun insanlar, salt insan olma

\footnotetext{
230 Nazime Beysan, Hak Kavramının Hukuk Felsefesi Açısından Analizi, On iki Levha Yayıncılık, İstanbul, 2015, s. 20.

231 Teorilerin gelişim süreçleri hakkında bkz. Beysan, s. 110 vd.; Demogue, s. 616-621.

232 Beysan, s. 186.

233 Kurki, s. 1080; Beysan, s. 248.

234 Serozan, s. 194.

235 Beysan, s. 248.

236 Serozan, s. 194

237 Beysan, s. 257.

238 Ibid.

239 Kurki, s. 1080.
} 
niteliğine bağl1 olarak, tam hak ehliyetine sahip kabul edilmektedir ${ }^{240}$. Hak sahipliğini irade unsurundan sıyıran menfaat teorisi, irade teorisinin açıklamakta yetersiz kaldığg ve pozitif hukukta yerleşik olan, kişinin feragat edemeyeceği haklar olgusu kadar, irade oluşturma yetisine sahip olmayan insanların da haklara sahip olması olgusunu açıklamakta ve bu şekilde çağdaş hukuk sistemlerinde cari olan hak ve hak sahipliği kavramlarında fiilen etkili olmaktadır ${ }^{241}$.

Hayvanların hak sahibi olarak tanınması meselesinde de bu teoriler ve hakkın temel unsuru olarak ileri sürdükleri irade unsuru ile menfaat unsurunun hangisinin baskın faktör olarak nazara alınacağı önem arzetmektedir. Hak kavramını irade unsuru üzerine kuranlar için hayvanların hak sahibi olarak olarak tanımlanabilmesi mümkün değildir; zira hayvanlar, irade teorisinin hak sahibi olabilmek için gerekli bir nitelik olarak kabul ettiği iradi seçim yapabilme yeteneğinden yoksundurlar ${ }^{242}$. Menfaat unsuruna ağırlık verilmesi halinde ise, hukuk düzenince korunmuş her menfaatin hak teşkil edip etmeyeceği sorunu ile karşılaşırız. Nitekim hukuk düzeninde salt kamunun yararını korumayı amaçlayan normların, belirli kişilere dolaylı yoldan koruma sağlamakta olmasının bu kişiler lehine öznel birer hak yaratmadığı, bu gibi durumlarda bir haktan değil, nesnel hukukun dolaylı bir yan etkisinden söz edilebileceği kabul edilmektedir ${ }^{243}$. Ancak, menfaat teorisi içinde bugün genel olarak kabul gören anlayış uyarınca, bu tür bir dolaylı yararlanma hali bulunmaksızın, bir başkasının menfaati veya toplumsal bir menfaatin dışında, kendilerine ait bir menfaate sahip ve bu menfaati korumaya yönelik korrelatif bir ödev yoluyla korunan tüm varlıklar hak sahibi olarak kabul edilebilir ${ }^{244}$. Hayvanları koruyucu normlara baktığımızda da bunların önemli bir kısmının başka bir kişinin menfaatini veya toplumsal bir menfaati değil, doğrudan doğruya hayvanların kendilerine ait menfaatlerini koruma amacı taşıdığını görmekteyiz. Temyiz kudretinden yoksun insanları da kendilerine ait menfaatleri nedeniyle, kendi iradelerinden bağımsız olarak koruyan hukuk sistemlerinin, bu anlayışı hayvanlara da teşmil etmesi, hak sahipliğinin menfaat teorisine dayandırılmasıyla teorik açıdan mümkün olacak, ve bu yolla hayvanların hak öznesi ve sahip oldukları haklar çerçevesinde hukuken kişi olarak nitelendirilmeleri sağlanabilecektir ${ }^{245}$.

\footnotetext{
240 Serozan, s. 194.

241 İrade öğesini ön plana çıkaran Windscheid ile menfaat öğesini vurgulayan Jhering'in görüşlerini uzlaştıran çağdaş hak tanımına göre, "hak, hukuk (devlet) tarafından, kişiye menfaatini tatmin edebilmesi için tanınmış ve özel olarak korunmuş bulunan bir irade erkidir. Tanımdaki ağırlığı ve yüklemi irade erkinden menfaate kaydıracak olursak, hak, kişinin hukukça tanınıp korunmasını sağlamaya muktedir sayıldığı menfaattir.” (Serozan, s. 192). Günümüzde benimsenen karma görüşe göre hakkın, "hukuken korunan ve sahibine korunmadan yararlanma yetkisi tanınan menfaat" olduğu yönünde, bkz. M. Kemal Oğuzman/Nami Barlas, Medeni Hukuk-Giriş, Kaynaklar, Temel Kavramlar, 23. Bası, Vedat Kitapçılık, İstanbul, 2017, s. 141

242 Beysan, s. 257.

${ }^{243}$ Serozan, s. 192-193. Her ödevin bir hakka karşllık gelmeyeceği düşüncesinden hareketle, menfaat teorisinin en basit şeklinde kabul edilen geniş hak sahibi kavramını daraltmaya çalışan çağdaş yaklaşımlar için, bkz. Beysan, s. 262 vd.

244 Beysan, s. 262.

245 Ancak, hayvan hakkının genel "hak" kavramından farklı bir kavram olduğu görüșü için, bkz. Cumalığlu, s. 582. Yazara göre, hayvan hakları kavramı, kişiler için yapılan tanımlardan farklı olmalıdır. Yazar, "hayvan hakkı" kavramını, kişinin ve devletin hayvanlar üzerindeki hakkının sınırı olarak ve "hukuken korunan ve insana ihlal etmeme yükümlülüğü getiren hayvan çıkarı" olarak tanımlamıştır (s. 582).
} 
Hak sahipliği ile hakkın kullanılmasının birbirinden ayrılması. Elbette, hayvanların sınırlı biçimde de olsa kişi olarak tanınmaları halinde, kendi haklarını savunma olanăg sorunu ortaya çıkmaktadır. Nitekim hayvanlar, tabi oldukları doğal engeller nedeniyle hiçbir zaman "reşit" hale gelememekte ve daimi olarak vesayet altında yaşamak zorunda kalmaktadır ${ }^{246}$. Ancak bu sorun, hukuk tarihinin önceki aşamalarında insanlar için de gündeme gelmiş ve hak ehliyeti ile fill ehliyetinin birbirinden ayrılması sonucuna götürmüş̧ür. Hayvanların olası haklarına riayet edilmesinin sağlanması, fiil ehliyeti bulunmayan insanların haklarının icrasından farklı bir nitelik taşımamaktadır ve yine bir vesayet mekanizmasının kurulması ile çözülmesinin mümkün olduğu görülmektedir. Keza tüzel kişilerin haklarını kullanmaları da organları vasıtasıyla mümkün olmaktadır. Bir yazarın da belirttiği gibi, bir varlı̆̆ın konuşamamasından hareketle hak sahibi olamayacağını iddia etmek doğru değildir; zira şirketler de, devletler de, küçük çocuklar da konuşamamaktadı2 ${ }^{247}$. Bir varlığın hukuk düzeninde hak sahibi olarak konumlandırılması için, onun bizzat konuşabilmesi değil, onun adına konuşabilecek kişilerin var olması gerekir ${ }^{248}$.

Haklara ve borçlara sahip olma ehliyetinin birbirinden ayrılması. Hayvanların borçlara sahip olma ehliyetinin bulunmaması, onlara hak ehliyeti tanınmasının önünde ciddi bir engel teşkil etmektedir. Nitekim pozitif hukukta cari olan hukuki kişilik kavramı, sadece haklara değil, aynı zamanda borçlarla da ehil olma yetisini içinde barındırmaktadır; borç sahibi olmanın hayvanlar açısından hiçbir anlamının bulunmayacağ 1 ise ortadadır. Ancak, hayvanlara insanlarla paralel olmayan, "teknik" bir kişilik tanınması düşüncesinin özünde de tam da kişilik kavramının hayvanların özel niteliklerine adapte edilerek uygulanması yatmaktadır. Bu adaptasyon, bir yandan hayvanlar açısından borç ve sorumluluk kavramlarının dışlanmasını ve diğer yandan da hayvanlara tanınan hakların onların ihtiyaç duyduğu çerçeve ile sınırlı olmasını gerektirmektedir. Hayvanların hukuki kişiliği ile kastedilen, insanlara sağlanan hukuki kişilik ile paralel bir oluşum değildir. Hayvanlara hukuki kişilik tanınması gerektiğini ifade ederek ${ }^{249}$ bu konudaki en iddialı ilkeyi 1989 tarihinde dile getirmiş olan Hayvan Hakları Evrensel Bildirgesi'nde dahi amaçlanan çözümün insanlarla paralel bir kişilik olmadığı görülmektedir. Bildirgeyi kaleme alanlar, burada söz konusu olanın hayvanların ihtiyaçlarına uyarlanmış bir faydalanma kişiliği ve hayvanlara özel hakların mahkemelerde savunulmasını sağlayacak yeni temsil yöntemlerinin geliştirilmesi olduğunu, bu alanda insanlara tanınan hukuki kişilik ile yapılacak kıyaslamaların yerinde olmayacağının altını çizmişlerdir ${ }^{250}$.

\footnotetext{
246 Chareix, s. 526.

247 Stone, s. 464.

248 Ibid.

249 Bkz. yuk. dn. no. 36.

${ }^{250}$ Neumann, s. 380.
} 
Hukuki kişiliğin bir konstrüksiyon olması. Hayvanlara tanınacak kişiliğin, hayvanların, insanlarla aynı seviyeye taşınmaları anlamına gelmeyeceği, hukuk düzeninde kişilik kavramının, insan görünümünden bağımsız ${ }^{251}$, teknik bir işleve sahip $^{252}$ olmasından da anlaşılmaktadır. Hukuki kişilik kavramının gösterdiği tarihi gelişim bu kavramın kurgusal niteliğini göstermektedir. Tüzel kişilik kavramı, münhasıran toplumun sosyo-ekonomik ihtiyaçları karşısında, kurgusal bir yaratım olarak karşımıza çıkmıştır. Bugün doğal olarak haklara sahip olduğu kabul edilen insanlar açısından da bu hakların hukuki planda tanınması görece yakın tarihte şekillenmiş bir anlayışın sonucudur. Tarihe baktığımızda hukuki kişilik statüsünün uzun zaman çeşitli insan gruplarına tanınmadığını veya sınırlı biçimde tanındığını görmekteyiz ${ }^{253}$. Bugün kabul edilen, tüm insanların hak ehliyetine sahip olduğu yönündeki kural, tarihi bir süreç sonucunda ve politik savaşlarla elde edilmiştirir ${ }^{254}$. Kişilik kavramının hukuk tarihinde gösterdiği gelişim, bu kavramın kurgusal niteliğini, hangi varlıkların, ne derece hukuken kişi olararak nitelendirileceğinin, toplumsal yargılar ve ihtiyaçlar çerçevesinde kanun koyucu tarafından belirlendiğini göstermektedir. $\mathrm{Bu}$ anlayış çerçevesinde, bugüne değin kişi olarak tanımlanmayan hayvanların, toplumun ulaştığı değerlere bağlı olarak, hukuk düzenince kişi olarak tanınması önünde bir engel bulunmamaktadır ${ }^{25}$. Hatta kişilik kavramının genişlemesine dikkat çeken bazı yazarlar, insan dışındaki canlı varlıklara da hak ehliyeti tanınmasını, hak ehliyeti çemberinin genişlemeye devam etmesinin beklenen bir sonucu olarak görmektedirler ${ }^{256}$. Ancak belirtelim ki, hukuki kişiliğin kurgusal niteliğinin kabulü, kişiliğin hukuk düzeninde tanınması işlemini salt bir tanımlama işlemine indirgemez. Özellikle insanlar açısından kişilik kavramının yaşadığı gelişim, haksız olarak bazı insanlardan esirgenen ehliyetin onlara tanınması anlamına gelmektedir. Bu durumda hayvanlardan da bu ehliyetin esirgenmesinin ne kadar haklı olduğu sorusu akla gelmekte ${ }^{257}$, ve hukuk düzeninin kişilik tanımlamasında hayvanlara yer vermemesinin hangi hukuk üstü kriterlere dayandığını sorgulamak gerekmektedir. Baka bir deyişle, hukuki kişilik kavramının kurgusal niteliğinin benimsenmesi, hayvanlara hukuki kişilik tanınmasının mümkün olduğunu göstermekte ve soruyu bunun gerekli olup olmadığı düzlemine taşımaktadır ${ }^{258}$.

Hayvanlara hukuki kişilik tanınmasının gerekliliği. Hayvanlara hukuki kişilik tanınmasını savunan yazarlardan bazıları, aslında hayvanların, insanlara yüklenen ödevlere karşılık gelen haklara zaten kavuşmuş olduğunu ve hayvanların halihazırda

\footnotetext{
251 Stone, s. 452

252 Marguénaud, s. 16.

253 Örnekler için bkz. Stone, s. 450 vd.

254 Stucki, Rechtstheoretische Reflexionen, s. 149.

255 Doğal varlıklar açısından bu yönde, bkz. Stone, s. 450 vd.

256 Stucki, Rechtstheoretische Reflexionens, s. 150.

257 Stucki, Rechtstheoretische Reflexionen, s. 150.

258 Idem, s. 152.
} 
de facto hak özneleri olduğunu savunmaktadırlar ${ }^{259}$. Ancak bu alanda çoğunluk tarafından benimsenen görüş, hayvanlara kişilik tanınmasının, klasik hayvan koruma hukukunun yarattığı ödevlerin, hayvanları hak öznesi k1lmakta ve koruma amacina ulaşmada yetersiz kaldığı yönündedir ${ }^{260}$. Bazı yazarlar, özellikle endüstriyel kullanım alanında hayvanlara getirilen korumanın yetersizliğine ve hayvanların sistematik olarak nesneleştirilmekte olmasına dikkat çekmiştir ${ }^{261}$. Öte yandan koruma sağlanan alanlarda da bu durumun gerçek anlamıyla hak yaratmak için yeterli olmadığı, nitekim hayvanlara sağlanan korumanın bir çekirdek içeriğe sahip olmadığ 1 ve oluşabilecek sonuçlara bakılarak ortadan kaldırılabilecek nitelikte olduğu ileri sürülmüştür ${ }^{262}$. Yukarıda görüşlerini aktardığımız Fransız hukukçu Demogue, hayvanların hak öznesi olarak görülmesinin, pratik sonuçlar doğuracağını, onlara sağlanacak korumayı kuvvetlendireceğini savunan yazarlar arasındadır. Yazara göre, hak öznesi niteliği, toplumda yaşayan insanlarca, hukuki kişilik tekniği yoluyla korunmaları için yeterli kadar önemli oldukları düşünülen menfaatlere ilişkindir ${ }^{263}$. Korunan menfaatin "kişi”" olarak kabul gören bir varlığa ilişkin olduğunun düşünülmesi, bu menfaatin korunması için hem hukuki hem de psikolojik açıdan daha büyük bir güvenliğin sağlanması sonucunu doğurmaktadır ${ }^{264}$. Amerikalı yazar Stone da bir varlığın hak sahibi olarak tanımlanmasının, onun başkalarının menfaatlerinin korunması yoluyla dolaylı olarak korunmasına nazaran operasyonel avantajlar sağladığını savunmuştur: Varlı̆̆ın kendisine ait menfaatlerin doğrudan doğruya bir yasal talebin sebebi olarak görülmesi, yasal çözümün uygulanması aşamasında bu varlığın kendisinin uğradığı zararın dikkate alınması, ve çözümün bu varlığın kendi menfaatlerine hizmet etmesi, ancak varlığın hak sahibi olarak görülmesiyle mümkün olacaktır ${ }^{265}$. Yazar ayrıca, koruma altında bulunan varlıkların "hak sahibi" olarak tanımlanmalarının, muğlak kuralların ne şekilde anlaşılacağı ve yorumlanacağı konusunda da etki yaratacağını, bu nedenle de bu tanımlamanın daha etkin bir koruma sağlayacağını belirtmiştir ${ }^{266}$.

\section{Hayvanların Ara Kategori Olarak Kabul Edilmeleri}

Bazı yazarlar, hayvanlara kişilik kazandırılması yerine, kişiler ve eşyalar arasında, bir ara kategorinin yaratılması çözümünü savunmuşlardır. Bu görüşteki Fransız hukukçu Farjat, hayyvanlarla olan ilişkimizdeki menfaatlerin çeşitliliğinin

\footnotetext{
259 Stucki, Die «tierliche Person», s. 296' da belirtilen yazarlar.

260 Idem, s. $301 \mathrm{vd}$.

261 Stucki, Die «tierliche Person», s. 302. Yazar, bu durumun, diğer hukuk alanlarında görülen ve bugün hayvan koruması etiğinde kurucu nitelikte olan özneleştirme eğilimi ile çelişki içinde olduğunu belirtmektedir.

262 Francione, Animal Rights s. 83-84.

263 Demogue, s. 630.

264 Ibid

265 Stone, s. 458. Yazar bir derenin kirlenmesinin hukuki sonuçlarını, dere kenarında oturan kișilerin haklarının ihlal edildiğinin kabul edildiği ve derenin kendi haklarının ihlal edildiğinin kabul edildiği iki senaryo çerçevesinde karșılaştırarak, birinci senaryonun derenin korunması amacına hizmet etmekten uzak kalabileceğini ortaya koymaktadır (s. $459 \mathrm{vd}$.)

266 Idem, s. 488.
} 
ve bu ilişkinin çelişkili karakterinin hayvanların hukuki statüsünün hukuki kişilik bağlamında ele alınmasına engel olduğunu ileri sürmüştür ${ }^{267}$. Yazara göre, bir hayvana veya ağaca hukuki kişilik tanınması anlamı ve etkinliği olmayan bir girişimdir: Hakların ne şekilde kullanılacağı sorunu bir yana, hayvanlar, hakların pasif olarak dahi öznesi olamazlar, nitekim malvarlığı kavramı hayvanlar için hiçbir anlam ifade etmez ${ }^{268}$. Ancak hayvanların ve doğanın, çağdaş toplumlar için ifade ettiği anlam da alelade eşya olmanın ötesine geçmektedir. Bu nedenle yazara göre hayvanlar, aile, şirket grupları, embriyo, kadavra ile birlikte, hukuki bir statüye ihtiyaç duyan ancak kişi veya eşya olarak tanımlanamayan diğer unsurlar ile birlikte, "menfaat merkezi" (centre d'intérêt) olarak adlandırdığı bir ara kategoriye ait olmalıdır. Böylece hayvanlar, kişiliğin korunması derecesine ulaşmayan, ancak eşya olarak muamele edilmenin ötesine geçen, kuvvetlendirilmiş bir korumaya sahip olabileceklerdir ${ }^{269}$. Yazara göre menfaat merkezi kavramı, içine giren unsurları hukuk sisteminin aktörleri haline getirmediğinden belirli fiili durumlara ihtiyaca göre farklı ölçülerde hukuki etki tanınmasını sağlayabilecek, böylece hukuki kişilik kavramını çarpıtmadan sosyal ihtiyaçlara cevap verebilecek bir kavramdır270. Hak öznesi kavramının da biyolojik veya psikolojik bir gerçeklik olmadığı, hukuk düzeninin üretimi olan bir kurgu olduğunu benimseyen yazar, bu tabloya bir soyutlamanın daha katılmasının ve menfaat merkezi kategorisinin tanınmasının önünde bir engel bulunmadığını savunmuştur ${ }^{271}$.

Yine Fransız hukukçu Antoine, hayvanların eşya olmadıklarını, eşya kavramından yola çıkarak savunmuştur. Yazara göre eşya kavramı, insanlar için faydaları üzerinden ölçülen ticari değerleri kategorize etmeye yaramaktadır. Oysa bir hayvanın değeri sadece ticari değildir, salt hayvanın piyasa değeri ile ölçülemez. Hayvan, canlı bir varlık olarak içsel bir değere de sahiptir ${ }^{272}$. Bu durum karşısında hayvanın doğasına uygun bir hukuki rejim oluşturabilmek için başvurulması gereken kavram, mülkiyet konusu eşya değil, canlı ve duyarlı varlık kavramı olmalıdır. Hayvan, eşya kategorisinden çıkarılmalı, hayvanlar için, sağduyuya ve hayvanın doğasının gerçekliğine uygun sui generis bir kategori yaratılmalıdır. Hayvan, istifade ettiği yasal korumanın dayattığı özel koşullar çerçevesinde mülkiyet konusu yapılan bir varlıktır, o kişi veya eşya değil, sadece "hayvan"dir ${ }^{273}$. Bununla beraber yazar, ekonomik fonksiyonları nedeniyle hayvanları eşya olarak benimsemeye devam etmemiz halinde, hayvanlara en azından

\footnotetext{
${ }^{267}$ Gérard Farjat, "Entre les personnes et les choses, les centres d'intérêts (prolégomènes pour une recherche)", Revue Trimestrielle de Droit Civil, 2002, s. 231-232. Ancak yazar, kişi- eşya karşıtlığının hukuk sistemini doğru şekilde ele almaya elverişli olmadığını, hukukun bu denli karmaşık hale geldiği bir dünyada bu karşıtlığa halen bu denli başvurulmasının şaşırtıcı olduğunu da ileri sürmektedir (s. 243-244).

268 Farjat, s. 238.

269 Ibid.

270 Idem, s. 242.

271 Idem, s. 244.

272 Antoine, s. 28.

273 Idem, s. 44.
} 
"korunan eşya" statüsü tanınması gerektiğini belirtmiştir. Bu durumda da hayvan, net bir hukuki tanıma kavuşacak ve kendi menfaati için korunmaya devam edecektir ${ }^{274}$.

\section{Hayvanların Özel Bir Eşya Kategorisi Olarak Kabul Edilmeleri}

$\mathrm{Bu}$ yaklaşımı savunan yazarlardan bazıları, ayrımın merkezine, hayvanları da içine alacak şekilde, canlı varlık kavramını koymakta, ve canlı varlığa kendine has bir statü tanınması gerektiğini ileri sürmektedirler. Bu görüşü savunan Libchaber, her ne kadar hukuki bir korumanın konusu olsalar da hayvanların, haklara ve borçlara ehil olmanın temelinde bulunan irade unsuruna sahip olmamaları nedeniyle kişi-eşya ayrımı altında kendilerine eşya dışında bir yer bulamayacağını savunmuştur. Ancak yazara göre, temel haklar kavramından yola çıkılarak hayvanların da kendilerine yer bulabileceği hukuki ayrımlara varılması mümkün olabilir. Bu görüşe göre, insanın, ahlaki planda sahip olduğu farklılıklardan çok, canlı varlık niteliği nedeniyle değer taşıdığının kabul edilmesi ve temel hakların da bu değere bağlanması mümkündür. Böylece insanoğlunun taşıdığ 1 değer, canlı varlık üst kategorisi içinde anlam kazanacak ve hayvanlar da bu anlamda insanoğlu ile aynı nitelikleri ve hakları paylaşacaktır. Yazar, türler arası ilişkilerin yarattığ açılardan insanoğlunun çevresindeki varlıklar ile aynı menfaatleri paylaştığına işaret etmektedir. Bu nedenle insanın korunmasının insanlık kavramından değil, canlı varlık kavramından yola çıkılarak kurgulanması, buna uygun olarak canlı varlığın yeni bir hukuki kategori haline getirilmesi ve böylece hayvanların da, eşya olarak kalmakla beraber, bugün insan haklarının sağladığı korumaya benzer bir korumadan yararlandırılması düşünülmelidir ${ }^{276}$.

Bir diğer görüşe göre kişi ve eşya arasındaki geleneksel ayrımın sorgulanmaması ve hayvanların özel nitelikli eşya olarak özel bir statüye kavuşturulması gerekir. Hayvanlara sağlanacak koruma, canlı eşya ile cansız eşya arasında hukuken işlevsel bir ayrım yapılması ${ }^{277}$, böylece eşya hukukunun yeniden kurgulanması yoluyla gerçekleştirilmelidir ${ }^{278}$. Bu görüş çerçevesinde hayvanlar mülkiyet konusu olarak kalabilecek, hayvanların, canlı ve duyarlı eşya karşısında insanlara yüklenen özel ödevler yoluyla korunmaları, hak öznesi haline getirilmelerine gerek olmaksızın sağlanabilecektir ${ }^{279}$.

274 Idem, s. 29.

275 Yazar, hayvanlardan geçebilecek bulaşıcı hastalıkların veya genetiği değiştirilmiş bitkisel organizmaların tüketiminin yaratabileceği mutasyon risklerinin insanoğlunun da felaketine yol açacağı yönündeki korkulara vurgu yapmaktadır; bkz Remy Libchaber, "Perspectives sur la situation juridique de l'animal", Revue Trimestrielle de Droit Civil, 2001, s. 243.

276 Idem, s. 242-243.

277 Reboul-Maupin, para. no 21. Yazara göre yaşayan eşyalar, malikleri için arz ettikleri ekonomik değerin ötesinde, toplumsal veya kişisel açıdan manevi bir anlam ifade eden varlıklar olarak kabul edilmeli, ancak geleneksel eşya ile kişi ayrımı, eşya kategorinin yeniden düzenlenmesi yoluyla muhafaza edilmelidir (Reboul-Maupin, para. no 24)

278 Idem, para. no. 20-21.

279 Idem, para. no. 22. Çevreyi, insan varlığını, hayvanları koruma yönündeki kaygıların eşya hukukunda canlı-cansız ayrımının doğmasına yol açtı̆̆ı yönünde, ayrıca bkz. Jean-Baptiste Seube, "Le droit des biens hors le Code Civil”, Petites affiches, S. 118, 15.06.2005, para no 13. Yazara göre eşya hukukunun içindeki bu gelişim, hak öznesi ile hak konusu arasındaki ayrıma 
Hayvanı eşya olarak nitelendiren yazarlardan Epstein, hayvanların eşya olma statüsüne ilişkin başka bir meseleye de değinmektedir: Yazara göre, hayvanların mülkiyet hakkı konusu olmalarının muhakkak hayvanların menfaatlerinin aleyhine bir durum yarattığı doğru değildir, hatta çoğu zaman bunun tam tersi geçerldir. Hayvanların insanlar tarafından sahiplenilmesi hayvanların doğal yaşam koşullarını olumsuz şekilde etkileyebileceği gibi olumlu şekilde de etkileyebilir. Pek çok alanda hayvanların mülkiyet konusu yapılmaları onların zararına değil, yararına sonuçlar doğurmuştur ${ }^{280}$. Öte yandan yazar, insanlarla kurulan benzerliğe de karşı çıkmakta ve iki tür arasındaki potansiyel farklılığının öneminin altını çizmektedir ${ }^{281}$. Yazara göre en yüksek gelişmişlik düzeyindeki hayvanın bile doğal olarak tabi olduğu bilişsel ve duygusal sınırlar tam bir eşitlik kurulması ihtimalini ortadan kaldırmaktadır. Ancak yazar, hayvanların alelade eşyalar olduğu fikrinde ısrar etmenin de artık akıl dış1 hale geldiğini, hayvanların fiziksel saldırıdan korunmalarının ve bazı yaşam alanları ile doğal besin maddeleri üzerinde sınırlı bir mülkiyet hakkına sahip olduklarının kabul edilmesini, bu yönde bir statü değişikliğinin gerekli olduğunu ileri sürmektedir. İnsanların çıkarlarını tehlikeye atmadan, hatta insanların durumunu da iyileştirerek hayvanların acı çekmesini azaltan yolların geliştirilmesi önemli öncelikler olarak kabul edilmeli, ancak hayvan menfaatlerinin per se korunması yoluna da gidilmemelidir ${ }^{282}$.

Hukukumuzda ise Başpınar, hayvanın mülkiyet konusu olarak kalmasının onun hukuken eşya olarak kabul edilmesini zorunlu kıldığını, ancak özel düzenlemeler yoluyla diğer eşyalara oranla farklı ve kendine özgü kurallara tabi kılınmış olduğunu savunmuştur. Yazara göre bu özel düzenlemeler sayesinde hayvanlara kendine özgü (sui generis) bir eşya statüsünün kazandırılması mümkün olabilir. Ancak hayvanın eşya olmaktan çıkması, ancak alım satıma, iktisaba, rehne konu olamayacak hale getirilmesi sonucunda söz konusu olabilir ${ }^{283}$. Nitekim hakkın konusu olan şey ancak eşya olarak nitelendirilebilir. ${ }^{284}$ Ertaş'a göre de hayvan sahiplerinin bunlar üzerindeki tasarruflarının cansız eşyalara göre önemli ölçüde sınırlandırılmış olması, bunların sahiplerine karşı hukuk düzeninin koruduğu nevi şahsına münhasır bir eşya grubu oluşturduğunun söylenmesini mümkün kılmaktadır ${ }^{285}$. Bununla beraber yazar, hayvanların hukuken eşya olmakla beraber, doğal hukuka göre, doğanın tüm canlılara tanımış olduğu üç temel hakka, yaşama, beslenme ve üreme haklarına sahip olduğunu belirtmektedir ${ }^{286}$.

da sıçrayacaktır. Hayvanlar üzerindeki mülkiyet hakkına ilişkin sınırlamaların yanında, insanın kendi vücudunun parçaları üzerindeki tasarruf yetkisine ilişkin gelişmeler bu ayrımın muğlaklaşmasına işaret etmektedir.

280 Epstein, s. 10-11.

281 Idem, s. 21.

282 Idem, s. $16 \mathrm{vd}$.

283 Başpınar, s. 1386.

284 Idem, s. 1385.

285 Ertaş, Çevre Hukuku, s. 478.

286 Idem, s. 478-479. 


\section{Değerlendirme ve Sonuç}

Çağdaş toplumların hayvanlara karşı bakış açısındaki değişiklikler, kendilerini bazen medeni hukuk ilişkilerini düzenleyen kurallarda, bazen hayvanları koruma amacıyla özel olarak çıkarılmış kanunlarda göstermektedir. Yapılan düzenlemeler, hayvanların eşya olmaktan çıkarılması, hayvan onuru kavramının veya hayvanın yaşama hakkının tanınması gibi genel nitelikte olabildiği gibi, belirli amaçlarla kullanılan hayvanlar üzerindeki mülkiyet hakkının belirli fillere ilişkin olarak sınırlandırılması şeklinde kendilerini gösterebilmektedir. Bu çerçevedeki hukuk kurallarının bazıları, hayvanları, sahiplerinin menfaatleri için, dolaylı olarak korumakta, bazıları ise, hayvanları doğrudan doğruya kendi menfaatleri ve içsel değerleri için korumaktadır. Bu durum bize çağdaş hukuk sistemlerinde hayvanların duyarlı varlıklar olarak korunmaya değer menfaatleri bulunduğunun kabul edildiğini göstermektedir. $\mathrm{Bu}$ itibarla hayvanların hukuken de diğer eşyalardan farklı bir noktada olduğunun kabul edilmesi gerekir. Ancak bu yeni anlayışın hayvanları mülkiyet konusu olmaktan çıkaracak kadar evrilmiş olmadığı da görülmektedir: Hayvanların korunması amacıyla getirilmiş hiçbir düzenleme, hayvanların ayni hakların konusu olduğu yönündeki geleneği sorgulamamaktadır. Kaldı ki hayvanlara olan ekonomik bağımlılı̆̆ımızın devam ediyor olması bu noktanın halihazırdaki gelişmişlik düzeyimizde sorgulanabilir durumda olmadığını da ortaya koymaktadır. İşte hayvanların hak konusu olarak kalmaya devam ediyor olmaları, hak öznesi/kişi olarak kabul edilmelerinin önünde mantıksal bir engel olarak görülebilmektedir ${ }^{287}$. Bununla beraber, hayvanların hak öznesi olarak görülmemesi de bizi başka bir çelişkiye götürmektedir. Nitekim hayvanların korunması amacıyla kişilerin mülkiyet hakkına getirilen sınırlamalar kamu yararı veya başka bir kişinin menfaatini koruma $^{288}$ amacına değil, bizzat hayvanın kendisinin korunması amacına hizmet etmektedir ${ }^{289}$. Bu durumda hayvan, kendisine getirilen koruma ile sinırlı olarak, sadece başkalarına yarayan bir araç olarak görülmemekte, kendi menfaatleri itibariyle hukuken tanınan bir değere sahip olmakta ${ }^{290}$ ve bu değer nedeniyle kendi sahibine karşı dahi korunmaktadır. Hayvanların, başka değerlerin korunması yoluyla dolaylı olarak değil, doğrudan doğruya hukuk düzenince korunuyor olmaları, hak sahibi olmadıklarını iddia etmeyi güçleştirmektedir. Böylece karşımıza, bir yandan hak konusu, bir yandan da hak sahibi olarak hukuk düzeninde kendine yer bulabilen bir varlık çıkmaktadır ${ }^{291}$.

\footnotetext{
287 Başpınar, s. 1385.

${ }^{288}$ Mülkiyet hakkına getirilen sınırlamaların mutat olarak izlediği bu amaçlar için, bkz. Ertaş, Eşya Hukuku, s. 213; Esener/ Güven, s. 183.

289 Marguénaud, s. 19.

290 Stone, s. 458. Bunun için de üç koşulun bir arada bulunması gerekir: Kendi isteği ile yasal taleplerde bulunabilmek, yasal telafinin uygulanmasının belirlenmesi aşamasında mahkemenin, bu varlığın bizzat kendisinin uğradığı zararı hesaba katması, yasal telafinin bu varlığın menfaatine hizmet etmesi (s. 458).

291 Hayvan türlerinin çeşitliliği karşısında her türe uyacak nitelemenin boş bir çaba olduğu, ve hayvanların sınıflara ayrılarak hak öznesi veya objesi olma niteliklerinin tespit edilmesi gerektiği yönündeki bir görüş için, bkz. Cumalığlu, s. 575.
} 
$\mathrm{Bu}$ veriler karşısında, hak öznesi ile hak nesnesi kategorilerinin, mutlak olarak birbirlerini dışlayıcı nitelikte olmadıklarını savunmanın mümkün olup olmadığg aklımıza gelir, nitekim hayvanlara ilişkin hukuki durum bize tam da bunu göstermektedir. Esasında geçmişten ve günümüzden gelen bazı örnekler, hak konusu olarak nitelendirilen bir varlığın, aynı zamanda bazı hakların da doğrudan yararlanıcısı olarak kabul edilmesinin, benzeri görülmemiş bir hukuki konstrüksiyon olmadığını göstermektedir.

Roma hukukunda kölelerin kişi olarak kabul edilmediği Roma hukukçuları tarafından genel olarak kabul edilmektedir ${ }^{292}$. Köleler, mülkiyet hakkının konusu birer eşya idiler ${ }^{293}$ ve insanlar için öngörülmüş tüm hukuki konumlar içinde, bir başkası tarafindan sahip olunabilecek tek insan kategorisini oluşturuyorlard $1^{294}$. Bu sınıflandırmanın sonucu olarak, efendinin köleyi bir başkasına devretmesi veya dilediği gibi kullanması mümkün görülüyor ${ }^{295}$, efendinin köleye zarar vermesi haksız fiil teşkil etmiyor ${ }^{296}$, efendinin kölenin üzerinde ölüm dirim hakkına bile sahip olduğu kabul ediliyordu ${ }^{297}$. Kölenin öldürülmeyip sahibi tarafindan terk edilmesi halinde köle özgürlügünü elde etmiyor, sahipsiz eşya durumuna geliyor ${ }^{298}$, böylece başka bir kişi tarafından mülkiyet altına alınabiliyordu ${ }^{299}$. Köleler, hukuken eşya oldukları için kurdukları ortak hayat evlilik olarak görülmez ve hukuki sonuç doğurmazd1 ${ }^{300}$. Hak ehliyetleri bulunmuyor, dolayısıyla haklardan yararlanamıyor, borç altına giremiyorlard ${ }^{301}$.

Bununla beraber, köle, eşya kategorisi altında özel bir tür eşya olarak görülmekteydi ${ }^{302}$. Nitekim mülkiyet konusu birer eşya olarak telakki edilen kölelerin

292 Alan Watson, "Thinking Property at Rome" Symposium on the Law of Slavery: Comparative Law and Slavery, Chicago-Kent Law Review, C. 68, 1992, s. 1355; Şahin Akıncı, Roma Hukuku Dersleri, 9. Bası, Sayram Yayınları, Konya, 2015, s. 165.

293 Peter A. J. Van Den Berg, "Slave: persons and property? : The Roman law on slavery and its reception in Western Europe and its overseas territories", Osaka University Law Review, Say1 63, 2016/2, s. 172; Özcan Karadeniz Çelebican, "Roma hukukunda peculium müessesesi”, Ankara Üniversitesi Hukuk Fakültesi Dergisi, C. 25, S. 3, 1968, s. 180; Edgar S. Shumway, "Freedom and Slavery in Roman Law", University of Pennsylvania Law Review, C. 49, 1901, s. 637; Akıncı, s. 165; Gülnihal Bozkurt, "Eski hukuk sistemlerinde kölelik", Ankara Üniversitesi Hukuk Fakültesi Dergisi, C. 38, S. 1, 1981, s. 93.

294 W. W. Buckland, The Roman Law of Slavery, The Lawbook Exchange, New Jersey, 2000, s. 10.

295 Richard Gamauf, "Slavery-Social Position and Legal Capacity", The Oxford Handbook of Roman Law and Society, ed. Du Plessis Paul J./ Ando Clifford/ Tuori Kaius, Oxford University Press, 2016, s. 386; Shumway, s. 637.

296 Bozkurt, s. 95; Akıncı, s. 168.

297 Selahattin Eren, "Roma Hukukunda Köle Mülkiyetinin Sınırları", Marmara Üniversitesi Hukuk Fakültesi Hukuk Araştırmaları Dergisi, C. 23, S. 3, 2017, s. 284; Akıncı, s. 165, 168.

298 Eren, s. 284; Van Den Berg, s. 177.

299 Van Den Berg, s. 177; Shumway, s. 637

300 Bozkurt, s. 94; Shumway, s. 637; Van Den Berg, s. 176; Akıncı, s. 166.

301 Bozkurt, s. 93; Van Den Berg, s. 176; Akıncı, s. 165; Gamauf, Slavery, s. 387.

302 Özcan Karadeniz Çelebican, Roma Eșya Hukuku, yeni Medeni Kanun'a uyarlanmıș 5. Bası, Turhan Kitabevi, Ankara, 2015, s. 32; Van Den Berg, s. 176. Justinian'ın Digest'inde tüm insanların doğal hukuka göre özgür doğduğu, kölelik kurumunun Ius Gentium çerçevesinde mümkün hale geldiği, hatta bu kurumun bir insanın diğerinin mülkiyeti haline gelmesinin doğaya aykırı olarak sağlanmış olduğu belirtilmektedir (Alan Watson (ed.), The Digest of Justinien, C. 1, English translation, University of Pennsylvania Press, 1998, s. 2, s. 15). Bu konuda ayrica bkz. Wise, Legal Thinghood, s. 500 vd. Bu itibarla kölelik kurumu, Roma hukukunda Ius Gentium ile Ius Naturale arasında bir çatışmanın olduğu tek durum olarak kabul edilmektedir (Buckland, s. 1). 
aynı zamanda birer insan olduğu da yadsınmıyordu ${ }^{303}$. Öyle ki özgürlügüün kazanan bir köle ${ }^{304}$ Roma vatandaşı haline gelebiliyor ${ }^{305}$, nesne olmaktan çıkınca kişi statüsüne girebiliyordu ${ }^{306}$. Öte yandan kişi olmak için gerekli tüm nitelikleri haiz bir Roma vatandaşı da esaret altına girmesi halinde köle, yani eşya haline geliyordu ${ }^{307}$. Bir insanın belirli bir dönem eşya, belirli bir dönem kişi olabileceğini kabul edilmesi, böylece insan varlığına ikili bir statü tanınması, bazı insanların eşya olarak nitelendirilmesinin felsefi değil, ekonomik sebeplere dayandığını, kölenin, vatandaş sınıfının ekonomik ihtiyaçlarının gerektirdiği ölçüde eşya olduğunu göstermektedir ${ }^{308}$. Nitekim kölelerin eşya statüsünde, bu ekonomik gereklerdeki gelişmeye paralel olarak hukuki planda da sapmalar olmuştur. Örneğin, kölelerin insan olarak acı çekme yetisine sahip olmaları, efendinin önceleri mutlak nitelikte görülen yetkisinin zaman içerisinde gittikçe genişleyen biçimde sınırlandırılması ile kendisini göstermiştir ${ }^{309}$. Konulan sınırlandırmalara riayet edilmesini sağlamak için, birer eşya oldukları için esasında dava ehliyeti bulunmayan kölelere efendilerini şikayet hakkı tanınmıştır ${ }^{310}$. Kölenin kendi aklını ve iradesini kullanarak yaptığı hukuki işlemlerden ötürü borç altına girmesinin kabulünü, kölenin malvarlığına sahip olmaması ile bağdaştırma zorunluluğu, kölelerin üstlendikleri borçların "eksik borç" olarak sınıflandırılmasına sebep olmuştur ${ }^{311}$. Bir insan olarak kölenin kendi aklını ve iradesini kullanarak ekonomik değeri olan işlemler yapabilme yetisi ve efendinin bu yetiyi kullanarak malvarlığı edinme yönündeki menfaati ise "peculium" müessesi yoluyla hukuki bir görünüme kavuşmuştur. Peculium, aile babasının veya efendinin, "aile evladına veya kölesine, bağımsız olarak yönetmek ve işletmek üzere

${ }_{303}$ Van Den Berg, s. 172; Gamauf, Slavery s. 387; aynı zamanda ailenin de bir parçası olduğu yönünde, bkz. Baha Yiğit Sayın, Roma Hukukundan Günümüze Obligatio Naturalis (Tabii Borç), yayımlanmamış doktora tezi, danışman Havva Karagöz, İstanbul Üniversitesi Sosyal Bilimler Enstitüsü, 2009, s. 127.

304 Kölelerin azat edilmesi usulleri için bkz. Akıncı, s. 170. Özellikle, ölüme bağlı tasarruf yoluyla kölenin, sahibinin ölümünden sonra özgürlüğüne kavuşmasının sağlandığı yönünde, bkz. Shumway, s. 648. Aile babasının, azat ettiği kölesine kölenin kullanımına tahsis edilen peculium'u da devredebildiği yönünde, bkz. Karadeniz Çelebican, Peculium, s. 189.

305 Öyle ki, azat edildikten sonra Roma vatandaşlığını kazanan kölelerin toplumun yapısını bozmaları nedeniyle zamanla köle azat edilmesine sınırlamalar getirilen kanunlar çıkarıldığı not edilmektedir (Shumway, s. 649; Akıncı, s. 163).

306 Van Den Berg, s. 175.

307 Özgür Roma yurttaşlarının belirli koşullarda köle statüsüne düşürülmelerinin mümkün olduğu yönünde, Karadeniz Çelebican, Eşya Hukuku s. 33; Akıneı, s. 164-165.

308 Yakalanan insanlar ilkel savaş zamanlarında katlediliyordu. Ancak tarım hayatının gelişmesi ile insan gücü ekonomik bir ihtiyaç haline gelmiş, böylece savaşlarda yakalanan insanların öldürülmelerindense ücretsiz işgücü olarak kullanılmaları ile birlikte kölelik doğmuştur (Shumway, s. 636-637; Akıncı, s. 163-164).

309 Bozkurt, s. 95; köle üzerindeki mülkiyet hakkının sınırlandırılması ile ilgili ayrıntılı bilgi için, bkz. Eren, s. 286 vd. Gaius'a göre köle mülkiyetinin sınırlandırılmasındaki amaç, malvarlığının mirasçılar menfaatine korunmasıydı. Köle isyanlarının yarattığı sınıfsal korkuların da kölelerin durumunu iyileştirmeye yönelten faktörlerden olduğu belirtilmektedir (Eren, s. $313,318)$

310 Kural olarak dava ehliyetine ve şikayet hakkına sahip olmayan kölelere, gaddarca ve ahlaka aykırı muamelelerin önüne geçmekle görevlendirilen bir magistra'ya efendiyi şikayet hakkının en geç Nero döneminde sağlandığı anlaşılmaktadır (Eren, s. 300). Jüri içermeyen, doğrudan magistra tarafından yürütülen bu prosedürün İmparatorluk zamanında yaratıldığg yönünde, bkz. Shumway, s. 640; ayrica bkz. Buckland, s. 2.

311 Böylece borçlu aleyhine dava açılamıyor, ancak borçlu veya efendisi borcu kendi rızası ile ifa ederse yapılan ödeme geri istenemiyordu; bkz. Akıncı, s. 168; Gamauf, Slavery s. 389, not 23; kölenin yaptığı ifanın hukuken muteber olarak algılandığı ve kölenin borcunun aile evladınınkiyle beraber, bir "de facto obligatio" olarak değerlendirilmesi gerektiği yönünde, bkz. Sayın, s. 134. 
verdiği mameleki" "312 ifade etmektedir. Bugünkü anlamda doğrudan temsil kurumunu tanımayan Roma toplumunda ${ }^{313}$, efendinin köleye aile mamelekinin bir kısmı üzerinde sınırlı bir yetki tanıması, kölenin, sonuçları efendi üzerinde doğacak bazı hukuki işlemleri yerine getirebilmesine, böylece efendinin kendisinin yetişemediği yerde malvarlığının yönetimini köleye bırakmasına olanak sağlamıştır. Kölenin hak ehliyeti ve kendine ait malvarlığı olmadığından, peculium üzerinde yaptığı hukuki işlemlerden doğan haklar efendiye ait oluyordu ${ }^{314}$. Bununla beraber, köle, efendisinin kendisine bıraktığı peculium'u kendi eşyasıymış gibi idare ediyor ${ }^{315}$, peculium büyük oranda kölenin de facto mülkiyeti olarak ifade ediliyor ${ }^{316}$, kölelere sağlanan peculium ciddi bir sebep olmadığ 1 sürece kendilerinden geri alınmıyordu ${ }^{317}$. Kölenin, efendisi adına hak edinebilmesi, sadece mülkiyet konusu değil, bir hukuki işlemin, kendi iradesi ile hareket eden enstrümanı olarak görüldüğ̈̈nü ortaya koymaktadır. ${ }^{318}$. Bu veriler, Roma hukukunda kölenin kural olarak eşya kategorisi içinde görülmekle birlikte, bazı hakların da yararlanıcısı olduğunu göstermektedir ${ }^{319}$. Bu kendine özgü statü, köleleri bir yandan eşya olarak nitelendiren, bir yandan onlara bazı haklar tanıyan diğer kölelik sistemlerinde de devam etmiştir ${ }^{320}$. Öte yandan Roma kişiler hukukunun çok katmanlı yapısı, ve köle olarak nitelendirilmeyen bazı insanların da pek çok haktan yoksun olmaları sadece bazı eşyaların değil, bazı kişilerin de kendine has bir statüye sahip olduklarını, Roma toplumunun eşya kavramı gibi

312 Karadeniz Çelebican, Peculium, s. 179; Richard Gamauf, "Slaves doing business: the role of Roman law in the economy of a Roman household", European Review of History C. 16, No 3, 2009, s. 331 vd. Peculium için ayrıca bkz. Akıncı, s. 169-170; Buckland, s. 188. Roma hukuku, bir evdeki tüm malvarlığı haklarını aile babasında toplamıştı. Aile babasının hakimiyeti altındaki kişilerin malvarlığına sahip olmaya ehil olmadıkları, ancak peculium adı verilen bu malvarlıksal bütünü yöneterek aile babasının mülkiyet edinmesini sağlamalarının mümkün olduğu kabul ediliyordu (Gamauf, Slaves, s. 331).

313 Karadeniz Çelebican, Peculium, s. 182.

314 Ibid., s. 182-184; Bozkurt, s. 94; Eren, s. 285; Van Den Berg, s. 176-177; Gamauf, Slaves, s. 335.

315 Watson, Thinking Property, s. 1356.

316 Van Den Berg, s. 176; Gamauf, Slaves, s. 340; Gamauf, Slavery, s. 395; Buckland, s. 188. Köleye verilen sermayenin hukuken efendiye, fiilen köleye ait olduğu yönünde, bkz. Akıncı, s. 169. Kölelerin "kendi paraları" ile özgürlüklerini satın alabilmeleri (Gamauf, Slavery, s. 395) peculium'un fiilen köleye ait görüldüğünü gösteren verilerden biridir.

317 Gamauf, Slaves, s. 334; Karadeniz Çelebican, Peculium, s. 188; peculium'un köleden geri alınmasının ahlaken hoş karşılanmadığı yönünde, Akıncı, s. 170.

318 Shumway, s. 637; bu durumun köleye kısmen de olsa kişilik tanındığını gösterdiği görüşünde, bkz. Eren, s. 285.

319 Bazı yazarlar, kölelerin Roma hukukunda salt eşya olarak sınıflandırılmadığını, hem eşyalar hem de kişilere ilişkin metinlerde kölelere yer verilmesinden yola çıkarak savunmuş ve Roma'da kişi ve eşya kategorilerinin birbirini dışlayıcı olmadığını ileri sürmüştür. Bu görüşe göre, kişi ve eşya kategorilerinin birbirlerini dışlayıcı hale gelmesi Roma uygarlığından daha sonraki aşamalarda gerçekleşmiş, bu gelişim sonucu Roma'da kölelerin kişiliğe sahip olmadıkları hatalı olarak iddia edilmiştir (Kurki, s. 1072 vd.) Bazı yazarlar ise Roma hukukunda kölenin durumunu eşyanın farklı şekillerde sınıflandırılabilmesi ve bu sınıflandırmanın maliklerin hakları ve ödevleri üzerinde farklı etkiler doğurabilmesi düşüncesi ile açıklamıșlardır. Bu görüșe göre, Roma hukuku, "res se moventes" eșyalar içinde ise ayrı bir kategoriyi, "düșünen mülkiyet” kategorisini köleler için yaratmıştır: Watson, Thinking Property, s. 1355. Bu statünün doğurduğu sonuçlar için, bkz. Watson, Thinking Property, s. 1355 vd. Kölelerin daha çok eşya mı insan mı oldukları, hukuki konumlarında peyderpey yaşanan iyileşmenin insancıl sebeplerle mi yoksa pragmatik sebeplerle mi gerçekleştiği sorularının, üzerlerinde fikir birliğine varılması muhtemelen imkansız olan sorular olduğu yönünde, bkz. Gamauf, Slavery s. 396.

320 Savaş öncesi Amerikan kölelik sisteminde kölelerin, eşya olarak nitelendirilmelerine rağmen hem haklara hem de ödevlere sahip oldukları kabul edilmektedir (Kurki, s. 1082). Ortaçağda, Roma anlayışına dayalı kölelik kurumunu benimseyen batı Avrupa yasalarından olan, Castile bölgesinin Siete Partidas Kanunu’nda kölelerin eşya olarak görülmekle beraber, evlenme hakkına da sahip görüldükleri (Van Den Berg, s. 178), keza Fransa'nın kolonilerinde uyguladığı 1685 tarihli Code Noir'ında da kölelerin taşınır eşya olarak tanımlandığı, ancak köleler arası evliliklere, böylece kölelerin aile kurmasına izin verildiği belirtilmektedir (Van Den Berg, s. 180-181). 
kişi kavramını da katmanlı biçimde değerlendirdiğini göstermektedir ${ }^{321}$. Nasıl eşya olarak sınıflandırılan köleler, bazı açılardan diğer insanlar gibi telakki edilmişse, eşya olarak sınıflandırılmayan, ancak aile babası otoritesi altında bulunan kişiler de çeşitli kısıtlamalara tabi tutulmuş, bazen eşyalarla aynı kaderi paylaşmışlardır ${ }^{322}$. Roma hukukunun hem kişilere, hem de eşyalara ilişkin bu pragmatik ve çok katmanlı yapısı, hayvanlara ilişkin olarak benimsenecek çözümün de bir ara katman olarak düşünülmesinin özgün nitelikte olmadığını göstermektedir ${ }^{323}$.

Esasında kişi ve eşya arasındaki ayrımın bulanıklaştığı çözümler günümüzdeki kurgulara da yabancı değildir ve özellikle ticaret şirketleri alanında karşımıza çıkmaktadır. Bu şirketlerin, ortaklarından bağımsız birer hak öznesi oldukları, kendilerine tüzel kişilik tanınması yoluyla benimsenmiştir (TTK m. 125). Bununla beraber, bir anonim ortaklıktaki pay sahiplerinin payları üzerinde tasarrufta bulunabilmeleri, paylarını üçüncü kişilere satılarak ekonomik fayda elde edilebiliyor olmaları, bir yandan hak öznesi olan şirketin, diğer yandan, sermayesinin parçalarını ifade eden paylar vasıtasıla, dolaylı da olsa ekonomik bir enstrüman işlevi gördüğünü, yani paylar vasitasıyla hak konusu olduğunu da göstermektedir.

Hayvanlar açısından da hayvanların mülkiyet konusu olmaya devam etmeleri nedeniyle hak nesnesi oldukları, doğrudan doğruya yararlandıkları koruma normları nedeniyle de, bu normların çizdiği sınırlar çerçevesinde hak öznesi oldukları söylenebilir. Toplumun hayvanları kullanma ve aynı zamanda korunmalarını da sağlama yönündeki ihtiyaçlarının uzlaştırılabilmesi için bu kendine has statünün kabulü en uygun çözüm olarak görünmektedir. Özne olma niteliğinin gelişimi, koruma

321 Hak ehliyetine sahip olmak için hür olmak, Roma vatandaşı olmak ve bir baba otoritesine tabi olmamak, yani aile babası statüsünde bulunmak gerekiyordu (Karadeniz Çelebican, Peculium, s. 180; Akıncı, s. 160). Bu üç şartı taşıyan kişiler de hak ehliyetini sınırlayıcı başka statüsel ayrımlara tabi tutulabiliyordu (Akıncı, s. 187 vd.). Baba hakimiyeti altındakilerin de statüsü kız veya erkek evlat olmalarına göre değişiyordu; aileye evlilikten sonra "manus" türü evlilik ile girmiş olan kadınların, "mancipatio" ile aileye katılan kişilerin her birinin durumları farklı idi (Karadeniz Çelebican, Peculium, s. 180). Vatandaş olmayanların, örneğin başka devletlerin vatandaşlarının hukuki durumu için bkz. Shumway, s. 642 vd.; Akıncı, s. 178-180. Özgür kadınların özel hukuk işlemlerinde bir vasi altında bulundurulması ile ilgili olarak (tutela), bkz. M. M. Wethmar-Lemmer, "The legal position of roman women: a dissenting perspective", Fundamina, C. 12, 2006, s. 178; Rena Van Den Bergh, "Roman Women: Sometimes Equal and Sometimes Not", Fundamina, C. 12, S. 2, 2006, s. 130; kadınların kamu görevinde bulunamadığı yönünde, bkz. Van Den Bergh, s. 127; ayrıca bkz. Epstein, s. 12-14. Kamu hukuku alanında kadınlara hiçbir hak tanınmadığı, özel hukuk alanında da vasi olma ve üçüncü kişi lehine borç altına girme ehliyetlerinin bulunmadığı yönünde, bkz. Akıncı, s. 191. Tüm bu katmanlar "persona" kavramının da çeşitli anlamlar üstlenebildiğini göstermektedir. Roma hukukunda "persona" kavramının anlamlarından birinin bireyin hukuki rolüne, yani her insanın hayatta temsil ettiği hukuki duruma, işleve ilişkin olduğu ifade edilmiştir: Başak Karaman, "Roma Hukukunda 'Persona' Kavramı”, Bahçeşehir Üniversitesi Hukuk Fakültesi Dergisi, S. 127-128, 2015, s. 81 vd.

322 Bazı evlilik türleri, kadının evlenmesinin satım sözleşmesine benzer nitelikler taşıdığını göstermektedir (coemptio) (Wethmar-Lemmer, s. 176; evlilik türleri hakkında ayrıntılı açıklama için bkz. Akıncı, s. 2209. In mancipio kişiler de, politik ve evliliğe ilişkin haklarını koruyor, ancak mancipium'u altında bulunduğu kişi tarafından köleler gibi devredilebiliyor, vasiyet konusu yapılabiliyordu (Shumway, s. 652-653). Roma hukukunda "özgür" insanın dahi alım satım konusu yapılabildiği, örneğin aile babasının evladı bir üçüncü kişiye satabildiği yönünde, bkz. Lazayrat, para. no. 11; Epstein, s. 12-14; KARADENIZ ÇELEBİCAN, Eşya Hukuku, s. 33, son yazar aile evladı üzerindeki egemenlik hakkının giderek mülkiyetten farkı bir nitelik kazandığını belirtmektedir. Aile babasının aile evlatlarını köle olarak satabileceği, kiralayabileceği, veya başka hukuki işlemlere konu yapabileceği yönünde, ayrıca bkz. Akıncı, s. 182.

$323 \mathrm{Bu}$ önerme, köleliğe övgü anlamına gelmemekte, insanların insan olmaları itibariyle sahip oldukları hak ehliyetinin daraltılabileceği sonucuna götürmemekte, Roma hukukunun ara kategorileri, hayvanlara hak ehliyeti tanınabilmesi, dolayısıyla doğadaki sömürü ilişkilerinin azaltılabilmesi amacı çerçevesinde kullanılabilecek olası hukuki yapıları düşündürücü nitelikleri nedeniyle hatırlatılmaktadır. 
normlarının kapsamının ve etkinliğinin genişlemesi ile paralellik gösterecektir. $\mathrm{Bu}$ açıdan, bazı ülkelerde atılmış hukuki adımların ülkemizde de takip edilmesinin fayda sağlayacağı muhakkaktır. Bu çerçevede, (i) hayvanların, ancak bünyelerine uygun düştüğü ölçüde eşya hükümlerine tabi tutulmaları, (ii) hayvanların menfaatlerini koruyucu hükümlerin çerçevesinin genişletilmesi ${ }^{324}$ (iii) hayvanların korunmasının anayasal ilke haline getirilerek onların temel menfaatlerinin insanların menfaatleri karşısında kategorik olarak feda edilmesinin engellenmesi ve (iv) yaratılan koruma normlarının uygulanmasını sağlayacak özel temsil usullerinin geliştirilmesi gerekmektedir. $\mathrm{Bu}$ yönde atılacak adımlar bu varlıkların ekonomik işlevini yadsımadığı için toplumun büyük kesimince kabul edilebilecek, ancak koruma alanını da peyderpey genişletebilecektir. Toplumun hayvanlara olan ekonomik bağımlılı̆̆1 zayıfladıkça hak öznesi olarak kendilerine tanınan alanın daha da genişlemesi mümkün olacaktır ${ }^{325}$.

Son olarak belirtelim ki, kişi ile eşya kavramlarının ve belki aralarındaki ayrımın yeniden düşünülmesi, sadece hayvanların değil, çağdaş toplumlarda yeni anlamlar kazanmış başka varlık ve ilişkilerin hukuk sistemine doğru şekilde entegre edebilmesi için de elzem bir nitelik taşımaktadır. Hayvanlar dışındaki canlı varlıklar, embriyo, insan vücudunun ayrılabilir parçaları, insan kadavrası, yapay zeka gibi unsurların sınıflandırılmalarının yarattığı hukuki güçlükler ${ }^{326}$, bu geleneksel ayrımın ve yarattığ 1 iki kategorinin birbirini dışlayıcı niteliğinin hukuki çözümleri ne kadar kolaylaştırıcı, ne kadar zorlaştırıcı olduğunu gözden geçirmeyi zorunlu kılmaktadır.

\section{Kisaltmalar Cetveli}

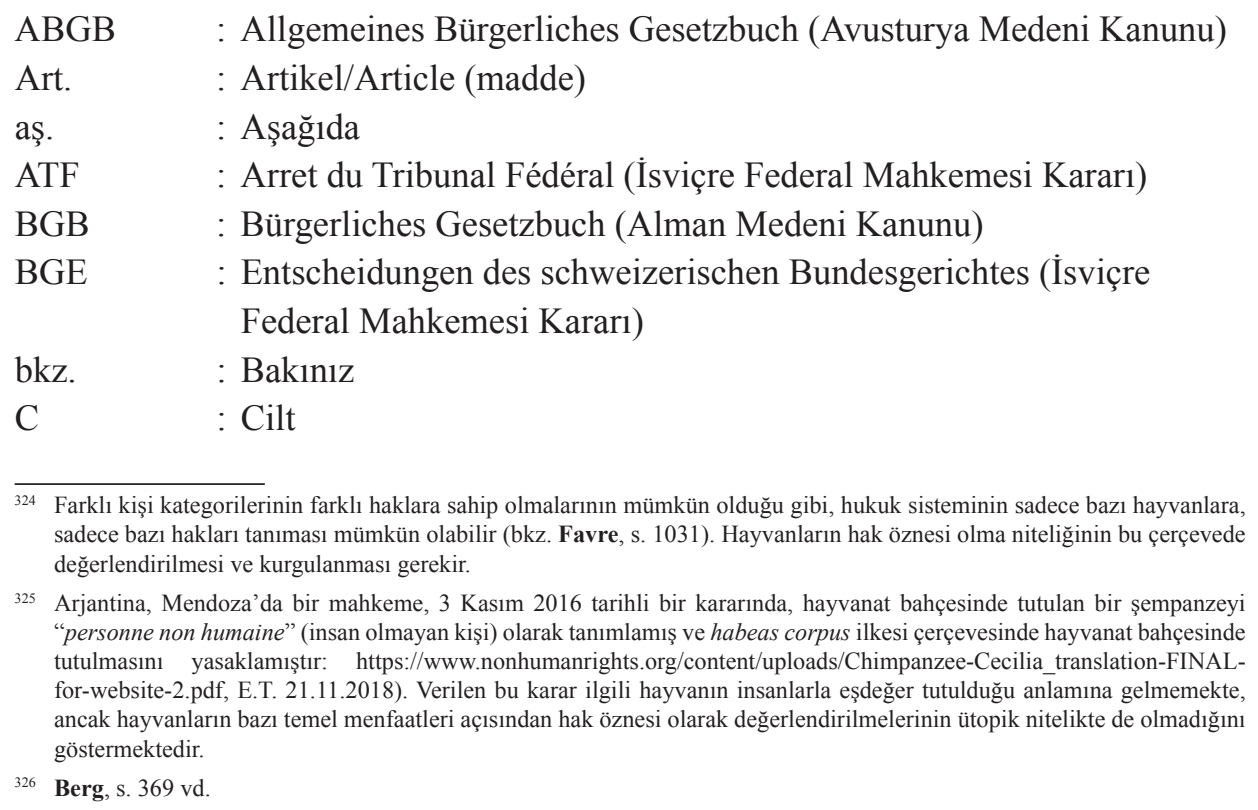




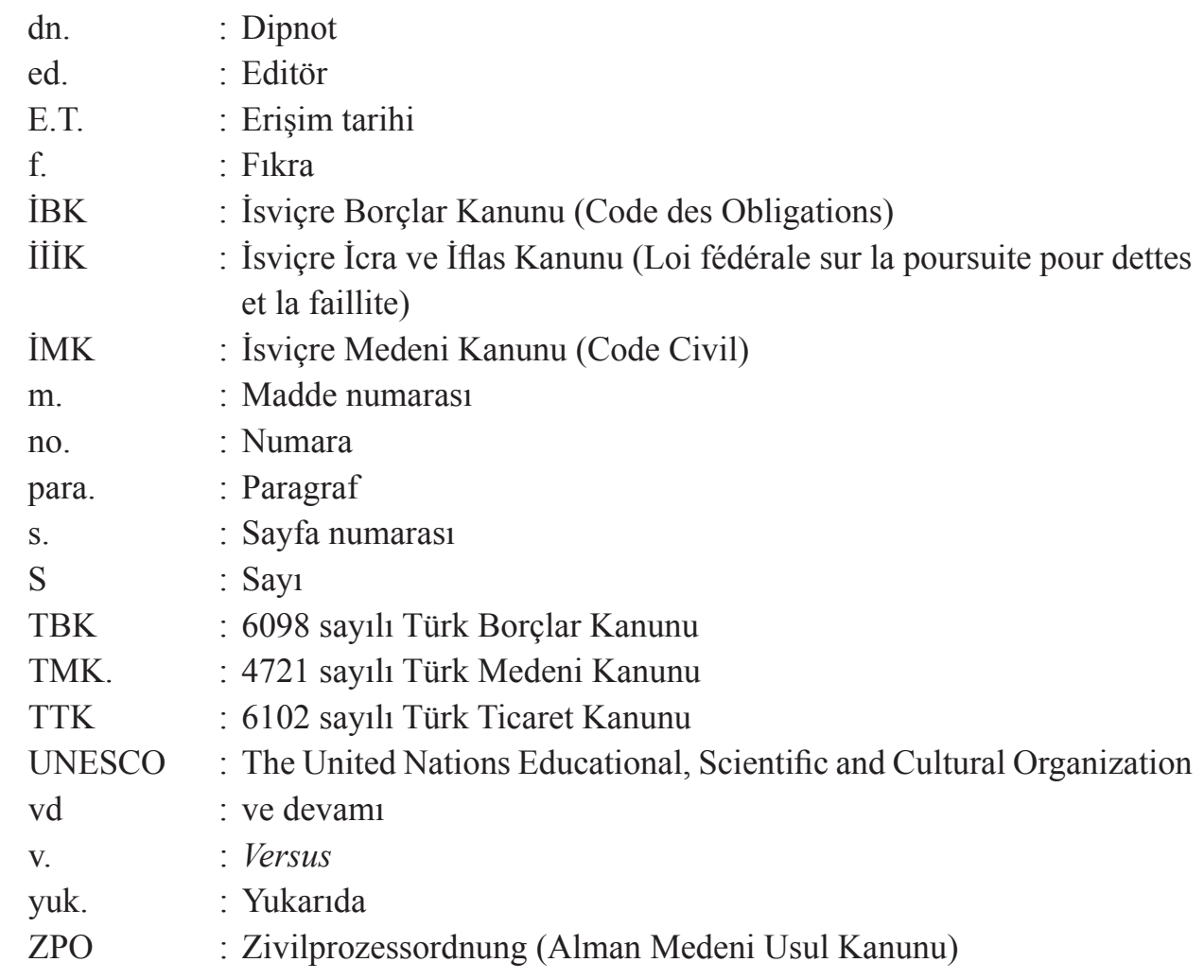




\section{Kaynakça/References}

Akıncı Şahin, Roma Hukuku Dersleri, 9. Bası, Sayram Yayınları, Konya, 2015

Aksoy Hüseyin Can, “Türk ve İsviçre Hukuklarında Evcil Hayvanlara Verilen Zararlara İlişkin Özel Hukuktan Doğan Sorumluluk”, Türkiye Barolar Birliği Dergisi, S. 129, 2017, s. 162-194

Aksoy Dursun Sanem, Eşya Kavramı, Oniki Levha Yayıncılık, İstanbul, 2012

Antalya O. Gökhan, Eşya Hukuku, Cilt 1, Legal Yayıncılık, İstanbul, 2017

Antoine Suzanne, Rapport sur le regime juridique de l'animal, ed. Fransa Adalet Bakanlığ (Ministère de la justice), May1s 2005, s. 1-50, https://www.ladocumentationfrancaise.fr/var/ storage/rapports-publics/054000297.pdf (E.T. 21.11.2018)

Arıkan Engin, Hayvan Hakları İnsan Hukuku, Ekin Basım Yayın Dağıtım, Bursa, 2016

Arnet Ruth, Art. 641a, Sachenrecht 641-977 ZGB, Handkommentar zum Schweizer Privatrecht, ed. Breitschmid Peter/ Jungo Alexandra, 3. Bası, Schulthess, Zürih, 2016, s. 16-17

Atlan Hülya, Manevi Zararı Tazmin Yolları, On İki Levha Yayınc1lık, İstanbul, 2015

Başpınar Veysel, “Eşya Hukuku Bakımından Hayvanların Hukukî Durumu”, 1926' dan Günümüze Türk İsviçre Medeni Hukuku, Medeni Kanun'un ve Borçlar Kanunu’nun 90. Yılı Uluslararası Sempozyumu, Yetkin Yayınları, İstanbul, 2016, s. 1343-1362.

Baur Jürgen F./Stürner Rolf, Sachenrecht, 18. Bası, C.H. Beck, Münih, 2009

Bentham Jeremy, An Introduction to the Principles of Morals and Legislation, 1789, online version by The University of Adelaide Library, 2014, https://ebooks.adelaide.edu.au/b/bentham/ jeremy/morals/index.html

Berg Jessica, "Of Elephants and Embryos: A Proposed Framework for Legal Personhood", Hastings Law Journal, C. 59, 2007, s. 369- 406

Beysan Nazime, Hak Kavramının Hukuk Felsefesi Açısından Analizi, On iki Levha Yayıncılık, İstanbul, 2015

Bolliger Gieri, “Animal Dignity Protection in Swiss Law-Status Quo and Future Perspectives", Schriften zum Tier im Recht, No 15, 2016, s. 17-41 (Kisaltma: Animal Dignity)

Bolliger Gieri, "Legal Protection of Animal Dignity in Switzerland: Status Quo and Future Perspectives”, Animal Law Review, C. 22, 2016, s. 311-395 (Kisaltma: Legal Protection)

Bozkurt Gülnihal, "Eski hukuk sistemlerinde kölelik", Ankara Üniversitesi Hukuk Fakültesi Dergisi, C. 38, S.1,1981, s. 65-103

Bradshaw Karen, "Animal Property Rights", University of Colorado Law Review, C. 89, 2018, s. 809-861.

Brehm Roland, "Les nouveaux droits du détenteur en cas de lésion subie par son animal (art. 42 al. 3 et 43 al. 1bis CO)", Responsabilité et assurance, 2003, s. 119-122

Broom Donald M., "Animal Welfare in the European Union", European Parliament, Policy Department for Citizens' Rights And Constitutional Affairs, 2017, http://www.europarl.europa. eu/RegData/etudes/STUD/2017/583114/IPOL_STU(2017)583114_EN.pdf, (E.T. 21.11.2018)

Buckland W. W., The Roman Law of Slavery, The Lawbook Exchange, New Jersey, 2000

Caire Anne-Blandine, "Les animaux ont-ils des droits? L'animal, eternel atopos?" La Revue "Le droit des animaux", S. 6, 2014, s. 3-17

Carius Manuel, “A la recherche de l'animal juridique", Revue de droit rural, 2015, no 432 (Kisaltma: Animal juridique) 
Carius Manuel, "Quel statut juridique pour le cheval?", Revue de droit rural, 2014, no 425 (Kisaltma: Quel statut)

Chappuis Christine, "Les nouvelles dispositions de responsabilité civile sur les animaux : que vaut Médor?", in: Le préjudice : une notion en devenir : Journée de la responsabilité civile 2004, ed. Chappuis Christine/Winiger Bénédict, Schulthess, Cenevre, 2005, s. 15-37

Chappuis Guy, “Les nouveaux droits du détenteur de l'animal tué ou blessé. Nouveaux, vraiment?", Responsabilité et Assurance, 2004, s. 92 -96

Chareix Fabien, “L'animal, entre personne et chose?", Revue de synthèse, C. 120, S. I. 4, 1999, s. $511-544$

Chiesa Luis E., "Animal Rights Unraveled: Why Abolitionism Collapses into Welfarism and What It Means for Animal Ethics", Georgetown Environmental Law Review, C. 28, 2016, s. 557-587

Cumalığlu Emre, "Medeni Hukukta Hayvan Hakları ve Hayvanlar Üzerindeki Hak", Dokuz Eylül Üniversitesi Hukuk Fakültesi Dergisi, Prof. Dr. Şeref Ertaş’a Armağan, Özel Sayı, C. 19, 2017, s. 573-610

Demogue René, "Le sujet de droit", Revue Trimestrielle de Droit Civil, 1909, s. 611-655.

De Poret Ombline, "L'animal en droit des successions", Successio - Revue de droit des successions, 2008, s. 118-143

Ellenberger Jürgen, Palandt-Bürgerliches Gesetzbuch, 71. Bas1, C.H. Beck, Münih, 2012

English David M., “The Uniform Trust Code (2000): Significant Provisions and Policy Issues", Missouri Law Review, C. 67, 2002, s. 143- 212

Epstein Richard A., "Animals as Objects, or Subjects, of Rights", University of Chicago Law School, John M. Olin Program in Law and Economics Working Paper No. 171, 2002, s. 1-35, https://chicagounbound.uchicago.edu/cgi/viewcontent.cgi?article=1052\&context=law_and economics, (E.T. 21.11.2018)

Erdenk Emre Arda, "Descartes' Account of Feeling of Pain in Animals", Felsefe ve Sosyal Bilimler Dergisi, S. 15, Bahar 2013, s. 201-210.

Eren Selahattin, "Roma Hukukunda Köle Mülkiyetinin Sınırları", Marmara Üniversitesi Hukuk Fakültesi Hukuk Araştırmaları Dergisi, C. 23, S. 3, 2017, s. 283-322

Ertaş Şeref, Eşya Hukuku, 13. Bası, Fakülteler Barış Kitabevi, İzmir, 2017

Ertaş Şeref, Çevre Hukuku ve Hayvan Hakları Hukuku, 2. Bası, İleri Kültür Merkezi, İzmir, 2012 (Kısaltma: Çevre Hukuku)

Esener Turhan/Güven Kudret, Eşya Hukuku, 7. Bası, Yetkin Yayınları, Ankara, 2017

Evans Erin, "Constitutional Inclusion of Animal Rights in Germany and Switzerland: How Did Animal Protection Become an Issue of National Importance?", Society and Animals, C. 18, 2010, s. 231-250

Falaise Muriel, "Pour une approche juridique de la protection animale", Communication au Colloque National de la Recherche dans les IUT, Université de Lyon I, 2008, s. 1-8, https:// projet.liris.cnrs.fr/cnriut08/actes/articles/205.pdf, (E.T. 21.11.2018)

Farjat Gérard, "Entre les personnes et les choses, les centres d'intérêts (prolégomènes pour une recherche) ", Revue Trimestrielle de Droit Civil, 2002, s. 221

Favre David, "Living Property: A New Status for Animals Within the Legal System", Marquette Law Review, C. 93, 2010, s. 1021-1070 
Flume Johannes W., BGB § 251, BeckOK BGB, ed. Bamberger Heinz George/Roth Herbert/Hau Wolfgang/Poseck Roman, 47. Bas1, C.H. Beck, Münih, 2018

Forbriger Anja, ZPO § 811c, BeckOK ZPO, ed. Vorwerk Volkert/Wolf Christian, C.H. Beck Münih, 2018

Francione Gary L., Rain Without Thunder-The Ideology of the Animal Rights Movement, Temple University Press, 1996 (Kisaltma: Rain Without Thunder)

Francione Gary L. /Garner Robert, The Animal Rights Debate- Abolition or Regulation?, Columbia University Press, 2010 (Kisaltma: Debate)

Francione Gary L., "Animal Rights and Animal Welfare", Rutgers University Law Review, C. 48, 1996, s. 397- 469 (Kisaltma: Animal Rights)

Gamauf Richard, "Slaves doing business: the role of Roman law in the economy of a Roman household”, European Review of History C. 16, No 3, 2009, s. 331-346 (Kisaltma: Slaves)

Gamauf Richard, "Slavery-Social Position and Legal Capacity", The Oxford Handbook of Roman Law and Society, ed. Du Plessis Paul J./ Ando Clifford/ Tuori Kaius, Oxford University Press, 2016 (Kisaltma: Slavery)

Genç Arıdemir Arzu, "Hayvanların Hukuki Konumlarının İyileştirilmesi Amacıyla İsviçre medeni Kanunu ile Borçlar Kanunu'nda Yapılan Değişikliklere Genel Bir Bakış”, Prof. Dr. Hüseyin Hatemi’ye Armağan, Cilt-1, Vedat Kitapç1lık, İstanbul 2009, s. 327-349.

Gergen Thomas, "Tiere in der deutschen Rechtsgeschichte und im geltenden Recht", Natur und Recht, C. 34, I. 2, 2012, s. 96-102

Gibson Miah, "The Universal Declaration of Animal Welfare", Deakin Law Review, C. 16, I. 2, 2011, s. 539-567.

Giroux Valery, "Des droits legaux fondamentaux pour tous les etres sensibles", Klesis - Revue philosophie, C. 16, 2010 - Humanité et animalité, s. 128-171

Graham-Siegenthaler Barbara, Art. 651a, Sachenrecht Art. 641-977 ZGB, Handkommentar zum Schweizer Privatrecht, ed. Breitschmid Peter/ Jungo Alexandra, 3. Bas1, Schulthess, Zürih, 2016

Gruber Urs, Münchener Kommentar zur ZPO, Band 2, ed. Krüger Wolfgang/Rauscher Thomas, 5. Bas1, 2016

Hadley John, "Nonhuman animal property: Reconciling environmentalism and animal rights", Journal of Social Philosophy, C. 36/3, 2005, s. 305-315

Haupt Claudia E., "The Nature and Effects of Constitutional State Objectives: Assessing the German Basic Law's Animal Protection Clause”, Animal Law Review, C. 16, 2010, s. 213-257

Helvacı Serap/Erlüle Fulya, Medeni Hukuk, 5. Bası, Legal Yayıncılık, 2018

Hubert-Froidevaux Anouchka, Art. 482, Commentaire du droit des successions (art. 457-640 cc; art. 11-24 LDFR), Commentaire Stämpfli, ed. Eigenman, Antoine/Rouillier Nicolas, Stämpfli Verlag AG, 2012, s. 108-124

İnal Tamer, "Hayvanın Hukuki Kişiliğinin ve Haklarının Tanınması Gereği Üzerine”, Kazancı Hukuk, İşletme ve Maliye Bilimleri Hakemli Dergisi, S. 1, 2004, s. 28-71

Karadeniz Çelebican Özcan, Roma Eşya Hukuku, yeni Medeni Kanun'a uyarlanmış 5. Bası, Turhan Kitabevi, Ankara, 2015 (Kısaltma: Eşya Hukuku)

Karadeniz Çelebican Özcan, "Roma hukukunda peculium müessesesi”, Ankara Üniversitesi Hukuk Fakültesi Dergisi, C. 25, S. 3, 1968, s. 179-194 (Kısaltma: Peculium) 
Karaman Başak, "Roma Hukukunda 'Persona' Kavramı", Bahçeşehir Üniversitesi Hukuk Fakültesi Dergisi, S. 127-128, 2015, s. 81-114

Kelch Thomas, "A Short History of (Mostly) Western Animal Law, Part I", Animal Law Review, C.19, 2012, s. 23-62 (Kisaltma: Part I)

Kelch Thomas, "A Short History of (Mostly) Western Animal Law, Part II", Animal Law Review, C. 19, 2013, s. 347-390 (Kisaltma: Part II)

Koçhisarlığlu Cengiz/Söğütlü Erişgin Özlem, "Hayvanın Hukuki Konumu”, Yaşar Üniversitesi Elektronik Dergisi, Prof. Dr. Aydın Zevkliler'e Armağan, C. 2, 2013-Özel sayı, s. 1691-1725.

Kolar Roman, "Three Years of Animal Welfare in the German Constitution-the Balance from an Animal Welfare Perspective", Altex C. 22, Özel Sayı 2, 2005, s. 146-149

Koons Judith E., "Earth Jurisprudence: The Moral Value of Nature", Pace Environmental Law Review, C. 25, 2008, s. 263-339.

Kurki Visa, "Animals, Slaves, and Corporations: Analyzing Legal Thinghood", German Law Journal, C. 18, S. 5, 2017, s. 1069-1090

Lazayrat Emmanuel/Rochfeld Judith/Marguénaud Jean-Pierre, "La distinction des personnes et des choses", Droit de la famille, S. 4, 2013, Etude 5

Le Bot Olivier, "Les Grandes Evolutions du Regime Juridique de l'Animal en Europe: Constitutionalisation et Dereification”, Revue Quebecoise de Droit International, C. 24, 2011, s. 249-257 (Kisaltma: Grandes evolutions)

Le Bot Olivier, "La protection de l'animal en droit constitutionnel. Etude de droit comparé", Lex Electronica, C. 12/2, 2007, s. 1-54 (Kisaltma: Protection de l'animal)

Lennkh Sabine, “The Animal: A Subject of Law? A Reflection on Aspects of the Austrian and German Juridical Systems", International Journal for the Semiotics of Law, C. 24, I. 3, 2011, s. 307-329

Libchaber Remy, "Perspectives sur la situation juridique de l'animal", Revue Trimestrielle de Droit Civil, 2001, s. 239

Loder Elizabeth, “Animal Dignity”, Animal Law Review, C. 24, 2016, s. 1-64

Malaurie Philippe/ Aynes Laurent/ Stoffel-Munck Philippe, Droit des Obligations, 9. Bas1, LGDJ, Paris, 2017.

Marguénaud Jean-Pierre, "Ni personne, ni objet, l'animal”, Bulletin de l'Académie Vétérinaire de France, C. 69, 1996, s. 15-23

Michel Margot/ Schneider Kayasseh Eveline, "The legal situation of animals in Switzerland: Two steps forward, one step back - many steps to go", Journal of Animal Law, C. 7, 2011, s. 1- 42

Michel Margot, “Tierschutzgesetzgebung im Rechtsvergleich: Konzepte und Entwicklungstendenzen", in: Animal Law-Tier und Recht, Developments and Perspectives in the 21st Century, ed. Michel Margot/Kühne Daniela/ Hänni Julia, Zürih/St. Gallen, 2012, s. 593-624.

Müller Christoph, Analyse de l'arrêt Tribunal fédéral 4A_241/2016 du 19 septembre 2017, Responsabilité et assurance, 2017, s. 45-47

Neumann Jean-Marc; “La Déclaration Universelle des Droits de l'Animal ou l'égalité des espèces face à la vie", in: Animal Law-Tier und Recht, Developments and Perspectives in the 21st Century, ed. Michel Margot/Kühne Daniela/ Hänni Julia Zürih/St. Gallen 2012, s. 361-395 
Oetker Hartmut, BGB $\S$ 251, Münchener Kommentar zum BGB, ed. Sacker Franz Jürgen/ Rixecker Roland/Oetker Hartmut/Limperg Bettina, 7. Bas1, C.H. Beck, Münih, 2016

Oğuzman M. Kemal/ Seliçi Özer/ Oktay-Özdemir Saibe, Eşya Hukuku, 20. Bası, Filiz Kitabevi, İstanbul, 2017

Oğuzman M. Kemal/Barlas Nami, Medeni Hukuk-Giriş, Kaynaklar, Temel Kavramlar, 23. Bası, Vedat Kitapçılık, İstanbul, 2017

Proctor Helen, “Animal Sentience: Where Are We and Where Are We Heading?", Animals C. 2(4), 2012, s. 628-639

Reboul-Maupin Nadege, "Pour une rénovation de la summa divisio des personnes et des biens", Petites affiches, S. 259, 28.12. 2016, s. 6

Reigné Philippe, "Les animaux et le Code Civil", La Semaine juridique-Edition générale, S. 9, 02.03 .2015 , s. 242

Rey Heinz, Die Grundlagen des Sachenrechts und das Eigentum, Stämpfli Verlag AG, Bern, 2007

Roy Alain, "Papa, Maman, Bebe et Fido: L'Animal de Compagnie en Droit Civil ou L'Emergence d'un Nouveau Sujet de Droit", Canadian Bar Review, C. 82, 2003, s. 791-807

Sayın Baha Yiğit, Roma Hukukundan Günümüze Obligatio Naturalis (Tabii Borç), yayımlanmamış doktora tezi, danışman Havva Karagöz, İstanbul Üniversitesi Sosyal Bilimler Enstitüsü, 2009.

Scalbert Louise, "Utilité et force symbolique du droit- A propos de la reconnaissance dans le Code Civil de l'animal comme "etre vivant doué de sensibilité"”, Revue de droit rural, S. 432, 2015

Schmid Jörg/ Hürlimann-Kaup Bettina, Sachenrecht, 4. Bas1, Schultess, 2012

Serozan Rona, Medeni Hukuk-Genel Bölüm/ Kişiler Hukuku, 7. Bası, Vedat Kitabevi, İstanbul, 2017

Serozan Rona/Engin Baki İlkay, Miras Hukuku ve Uygulama Çalışmaları, 5. Bası, Seçkin Yayıncılık, Ankara, 2018

Seube Jean-Baptiste, "Le droit des biens hors le Code Civil”, Petites affiches, S. 118, 15.06.2005, s. 4

Shumway Edgar S., "Freedom and Slavery in Roman Law", University of Pennsylvania Law Review, C. 49, 1901, s. 636-653

Sobbrio Paola, "The Relationship between Humans and other Animals in European Animal Welfare Legislation", Relations. Beyond Anthropocentrism, C. 1, 2013, s. 33-46

Steinauer Paul-Henri, “Tertium datur?”, in: Figures juridiques, Mélanges dissociés pour Pierre Tercier à l'occasion de son soixantième anniversaire, ed. Gauch Peter/Pichonnaz Pascal, Cenevre/Zürih/ Basel, 2003, s. 51 (Kisaltma: Tertium datur)

Steinauer Paul-Henri, Les droits réels, Tome I, 5. Bas1, Stämpfli editions SA, Bern, 2012 (Kisaltma: Droits réels)

Stone Christopher D.,"Should Trees Have Standing? - Toward Legal Rights for Natural Objects", Southern California Law Review, C. 45, 1972, s. 450-501

Stresemann Christina, BGB § 90a, Münchener Kommentar zum Bürgerlichen Gesetzbuch, Band 1: Allgemeiner Teil §§ 1-240, 7. Bas1, C.H. Beck, 2015

Stucki Saskia, "Rechtstheoretische Reflexionen zur Begründung eines tierlichen Rechtssubjekts", in: Animal Law-Tier und Recht, Developments and Perspectives in the 21st Century, ed. Michel Margot/Kühne Daniela/ Hänni Julia, Zürih/St. Gallen, 2012, s. 143-172 (Kısaltma: Rechtstheoretische Reflexionen) 
Stucki Saskia, "Die «tierliche Person» als Tertium datur-Eine Extrapolation aus aktuellen tierschutzrechtlichen Subjektivierungsansätzen und kritische Reflexion aus feministischer Perspektive”, in: Würde der Kreatur- ethische und rechtliche Beiträge zu einem umstrittenen Konzept, ed. Ammann Christoph/ Christensen Birgit/ Engi Lorenz/ Michel Margot, Schulthess, 2015, s. 287-326 (Kisaltma: Die «tierliche Person»)

Studhalter Philipp, Art. 482, ZGB Kommentar-Schweizerisches Zivilgesetzbuch, ed. Kren Kostkiewicz Jolanta/ Wolf Stephan/ Amstutz Marc/ Fankhauser Roland, 3. Bas1, Orell Füssli, 2016, s. 961-966

Sungurbey İsmet, Hayvan Hakları-Bir İnsanlık Kitabı, İ. Ü. Basımevi ve Film Merkezi, İstanbul, 1992

Trahan John R., "The Distinction Between Persons \& Things: An Historical Perspective”, Journal of Civil Law Studies, C.1, 2008, s. 9-20

Uyumaz Alper, "Bir Hukuk Sorunsalı Olarak Güncel Gelişmeler Işs̆ğında Türkiye'de Hayvan Hakları”, Gazi Üniversitesi Hukuk Fakültesi Dergisi, C. 20, S. 3, 2016, s. 133-184

Van Den Berg Peter A. J., "Slave: persons and property?: The Roman law on slavery and its reception in Western Europe and its overseas territories", Osaka University Law Review, S. 63, 2016/2, s. $171-188$

Van Den Bergh Rena, "Roman Women: Sometimes Equal and Sometimes Not", Fundamina, C. 12, S. 2, 2006, s. 113-136.

Watson Alan, "Thinking Property at Rome" Symposium on the Law of Slavery: Comparative Law and Slavery, Chicago-Kent Law Review, C. 68, 1992, s. 1355- 1371 (Kisaltma: "Thinking Property")

Watson Alan (ed.), The Digest of Justinien, C. 1, English translation, University of Pennsylvania Press, 1998

Werro Franz, "Le tort moral, le contrat et la perte d'une chose", in: Une empreinte sur le Code Civil Mélanges en l'honneur de Paul-Henri Steinauer, ed. Rumo-Jungo Alexandra/ Pichonnaz Pascal/ Hürlimann-Kaup Bettina/ Fountoulakis Christiana, Stämpfli 2013, s. 855-869

Wethmar-Lemmer, M. M., "The legal position of roman women: a dissenting perspective", Fundamina, C. 12, 2006, s. 174-184

Wiegand Wolfgang, Art. 641a, Zivilgesetzbuch II, Basler Kommentar, Honsell Heinrich/Vogt Nedim Peter /Geiser Thomas, 5. Bas1, Helbing Lichtenhahn Verlag, 2015

Wise Steven M., "The Legal Thinghood of Nonhuman Animals", Boston College Environmental Affairs Law Review, C. 23, 1996, s. 471-546 (K1saltma: Legal Thinghood)

Wise Steven M., "Introduction to Animal Law Book", Syracuse Law Review, C. 67, 2017, s. 7- 30 (Kisaltma: Introduction)

Wise Steven M., "Nonhuman Rights to Personhood", Pace Environmental Law Review, C. 30, 2013, s. 1278-1290 ( K1saltma:Nonhuman Rights)

Wolf Stephan, Art. 641a, ZGB Kommentar- Schweizerisches Zivilgesetzbuch, ed. Kren Kostkiewicz Jolanta/ Wolf Stephan/ Amstutz Marc/ Fankhauser Roland, 3. Bas1, Orell Füssli, 2016, s. 1222-1223

Wright Glenn, "Animal Law and Earth Jurisprudence: A Comparative Analysis of the Status of Animals in Two Emerging Discourses", Australian Animal Protection Law Journal, C. 9, 2013, s. 5-29. 